\title{
ISCED 2011 Operational Manual GUIDELINES FOR CLASSIFYING NATIONAL EDUCATION PROGRAMMES AND RELATED QUALIFICATIONS
}

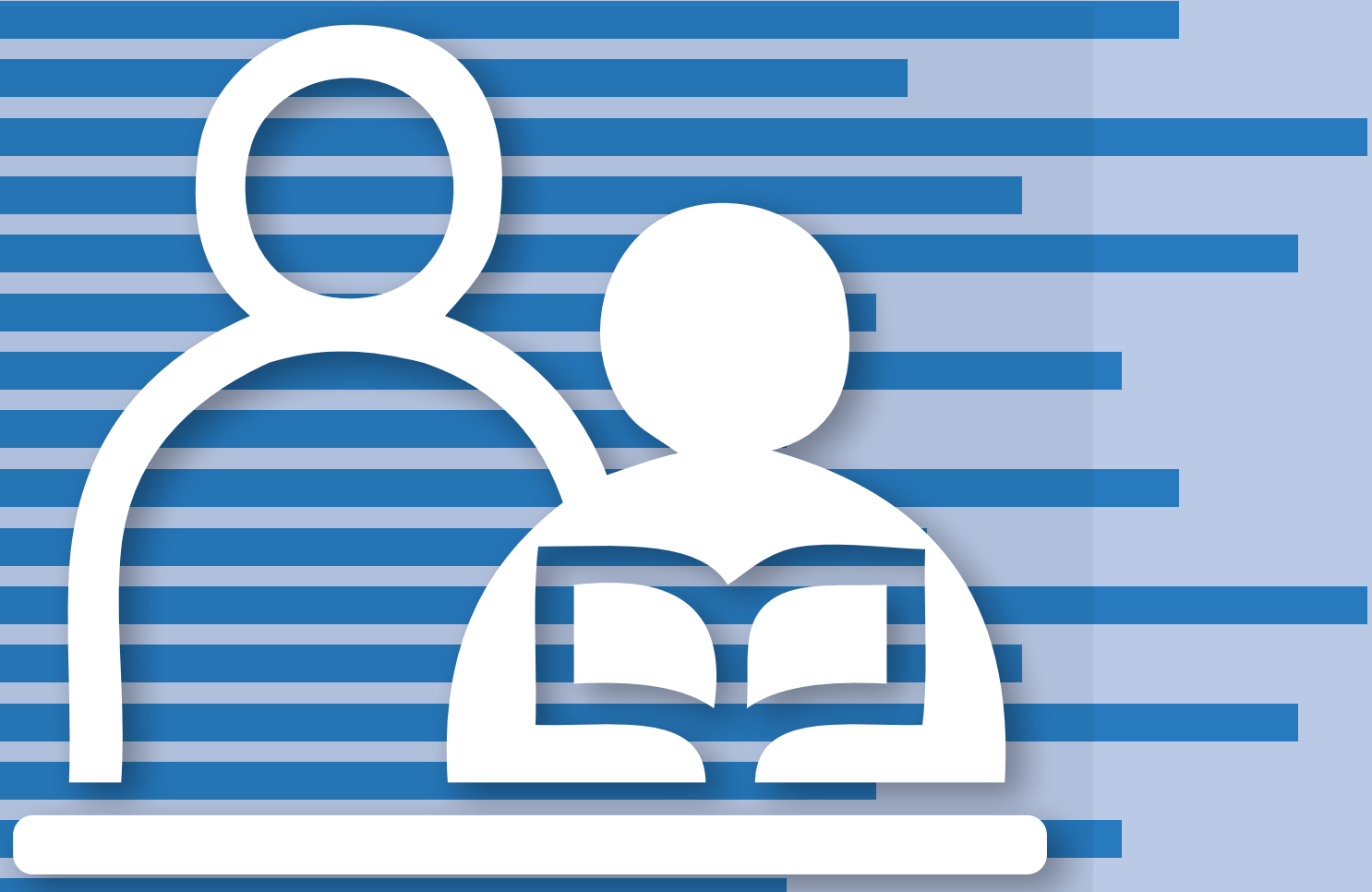





\title{
ISCED 2011 \\ Operational Manual
}

\author{
GUIDELINES FOR CLASSIFYING \\ NATIONAL EDUCATION PROGRAMMES \\ AND RELATED QUALIFICATIONS
}


This work is published under the responsibility of the Secretary-General of the OECD. The opinions expressed and arguments employed herein do not necessarily reflect the official views of the OECD member countries or of the European Union or of the UNESCO Institute for Statistics.

This document and any map included herein are without prejudice to the status of or sovereignty over any territory, to the delimitation of international frontiers and boundaries and to the name of any territory, city or area.

UIS ISBN 978-92-9189-174-0

OECD ISBN 978-92-64-22835-1 (print) OECD ISBN 978-92-64-22836-8 (PDF)

European Union

ISBN 978-92-78-41240-1 (print)

ISBN 978-92-78-41239-5 (PDF)

Catalogue number

KS-06-14-246-EN-C (print)

KS-06-14-246-EN-N (PDF)

The statistical data for Israel are supplied by and under the responsibility of the relevant Israeli authorities. The use of such data by the OECD is without prejudice to the status of the Golan Heights, East Jerusalem and Israeli settlements in the West Bank under the terms of international law.

Corrigenda to OECD publications may be found on line at: www.oecd.org/publishing/corrigenda.

(C) OECD, European Union, UNESCO-UIS 2015

This work is available under the Creative Commons Attribution-NonCommercial-NoDerivatives 3.0 IGO license (CC BY-NC-ND 3.0 IGO) http://creativecommons. org/licenses/by-nc-nd/3.0/igo/deed.en, you are free to copy and redistribute the material, provided the use is for non-commercial purposes, under the following conditions:

Attribution - Please cite the work as follows: OECD, European Union, UNESCO Institute for Statistics (2015), ISCED 2011 Operational Manual: Guidelines for Classifying National Education Programmes and Related Qualifications, OECD Publishing. http://dx.doi.org/10.1787/9789264228368-en. Creative Commons Attribution CC BY-NC-ND 3.0 IGO.

Third-party content - The OECD, the European Union or the UNESCO Institute for Statistics do not necessarily own each component of the content contained within the work. Therefore, neither the OECD, nor the European Union or the UNESCO Institute for Statistics warrant that the use of any third-party owned individual component or part contained in the work will not infringe on the rights of those third parties. The risk of claims resulting from such infringement rests solely with you. If you wish to re-use a component of the work, it is your responsibility to determine whether permission is needed for that re-use and to obtain permission from the copyright owner. Examples of components can include, but are not limited to, tables, figures, or images. All requests for commercial use or queries on rights and licenses should be addressed to OECD e-mail: rights@oecd.org. Requests for permission to photocopy portions of this material for commercial use should be addressed directly to the Copyright Clearance. 


\section{Foreword}

The structure of education systems varies widely between countries. In order to produce internationally-comparable education statistics and indicators, it is therefore necessary to have a framework to collect and report data on education programmes (and their resulting qualifications) with a similar level of educational content. It is for this purpose that the International Standard Classification of Education (ISCED) exists, as the official classification used to categorise and report cross-nationally comparable education statistics.

The ISCED classification was initially developed by UNESCO in the mid-1970s and was first revised in 1997. Due to subsequent changes in education and learning systems throughout the start of the 21 st century, a further review of ISCED was undertaken between 2009 and 2011 involving extensive global consultations with countries, regional experts and international organisations. The revision took into account important shifts in the structure of higher education such as the Bologna process in Europe, the expansion of education programmes for very young children, and an increasing interest in statistics on the outcomes of education (e.g. educational attainment). The revised ISCED 2011 classification was adopted by the UNESCO General Conference at its 36th session in November 2011.

The present ISCED 2011 Operational Manual: Guidelines for Classifying National Education Programmes and Related Qualifications has been prepared jointly by the UNESCO Institute for Statistics (UIS), the OECD and Eurostat, and takes into account multiple consultations on the mappings of national education systems to ISCED 2011. The publication was prepared under the responsibility of Alison Kennedy from the UNESCO Institute for Statistics (UIS); Éric Charbonnier and Nhung Truong from the Innovation and Measuring Progress Division (IMEP) of the OECD Directorate for Education and Skills; and Marta Beck-Domżalska from Eurostat.

The goal of this operational manual is to assist countries in the implementation of ISCED 2011 and to ensure that the mappings of national education systems to the revised ISCED framework are transparent. The implementation of ISCED 2011 should be both an iterative and an interactive process, in which consensus on mappings can be built between countries and international organisations for the purpose of enhancing comparability in the international reporting of education statistics.

The publication of this operational manual is an important step forward in a long-term consultative process designed to continually improve the comparability of international statistics on education. 


\section{Acknowledgements}

Many people have contributed to the development of this publication.

Thank you in particular to all countries for the elaboration of their national ISCED mappings without which this publication would not have been possible.

The OECD wishes to thank all experts and institutions working within the framework of the OECD Indicators of Education Systems (INES) Working Party, the delegates of the INES Network on Labour Market, Economic and Social Outcomes of Learning (LSO), and the participants of the INES Early Childhood Education Informal Working Group for their valuable contributions.

Eurostat would like to thank the members of the Education and Training Statistics (ETS) Working Group who commented on various parts of the manual and all colleagues in the countries collaborating in the ISCED mappings review.

The UNESCO Institute for Statistics (UIS) would like to thank all national experts who attented workshops and submitted mappings for review. UIS would also like to thank the Government of Japan for the financial support provided for the implementation of ISCED 2011 in the Asia and Pacific region through the Japanese Funds-In-Trust to UNESCO and the Arab League's Educational, Cultural and Scientific Organization (ALECSO) which funded regional training workshops for the Arab States.

Gratitude is also extended to the French delegates for the preparation of the summary table of ISCED 2011 codes and criteria (Annex A of the operational manual) and the many other colleagues who made substantial contributions or provided comments that supported the preparation of this manual. 


\section{Table of contents}

READER'S GUIDE

PART I ISCED 2011 OVERVIEW.

CHAPTER 1 ISCED 2011 OVERVIEW.....

What is ISCED and what are its units of classification?

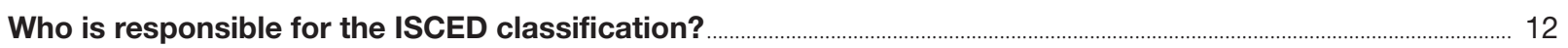

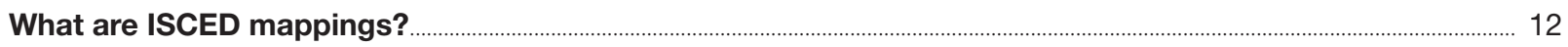

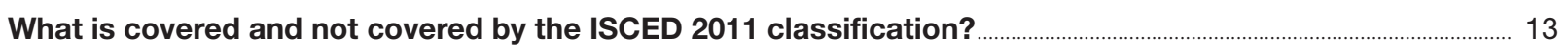

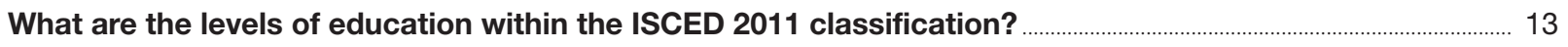

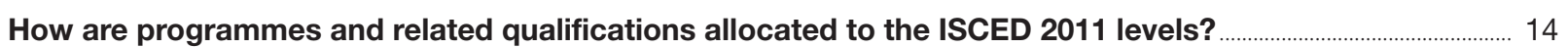

How are programmes that span ISCED levels, are sequential or are comprised of modules classified

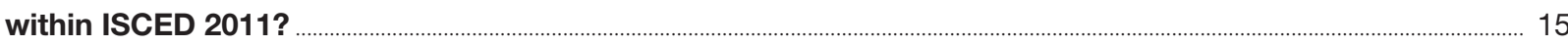

By what complementary dimensions can programmes and qualifications be further classified

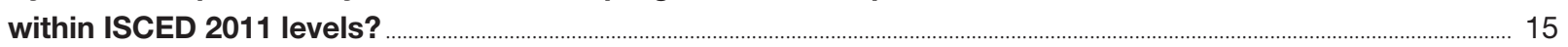

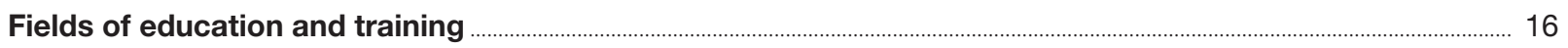

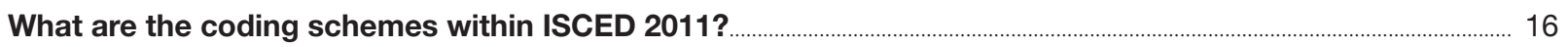

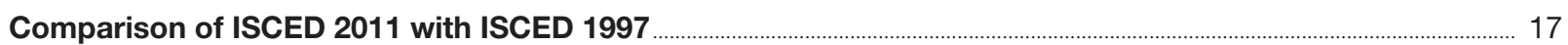

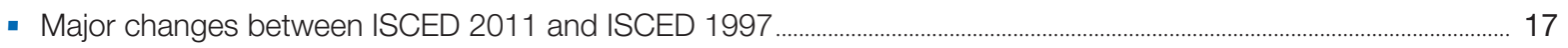

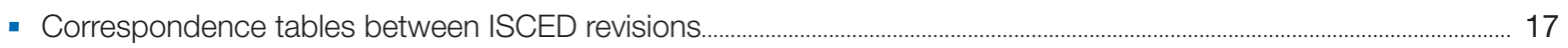

PART II ISCED 2011 LEVELS 0 TO 4: FROM EARLY CHILDHOOD EDUCATION

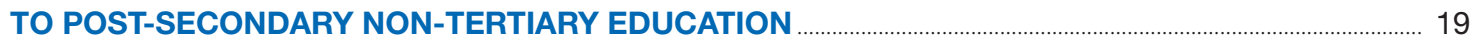

CHAPTER 2 ISCED 2011 LEVEL 0: EARLY CHILDHOOD EDUCATION ……............................................................ 19

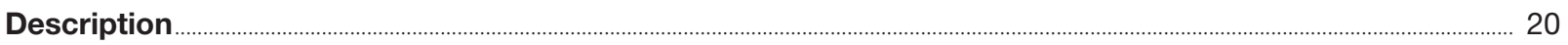

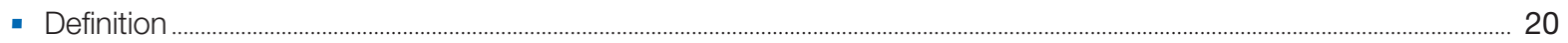

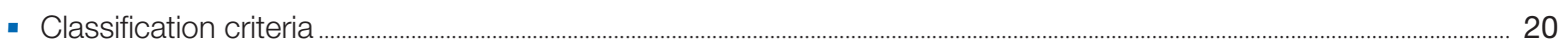

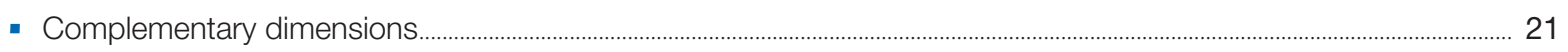

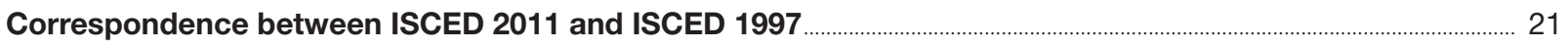

Guidelines for classifying programmes and their related recognised qualifications at ISCED level $0 \ldots \ldots \ldots \ldots . . .22$

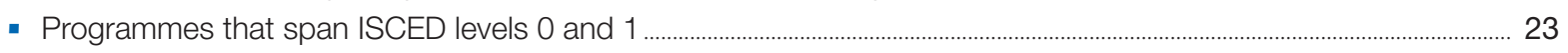

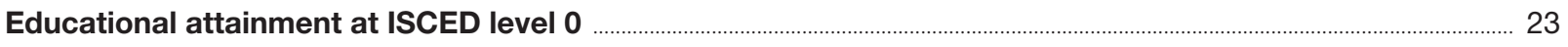

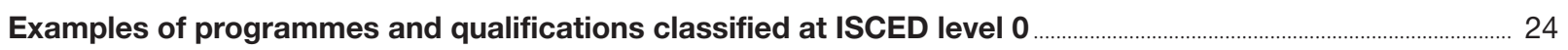

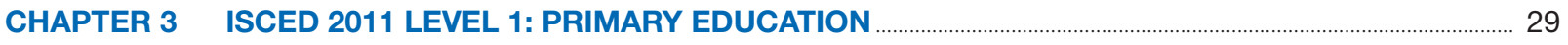

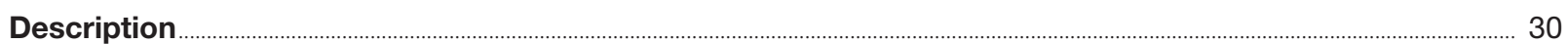

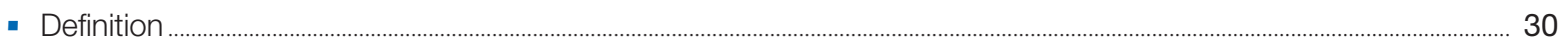

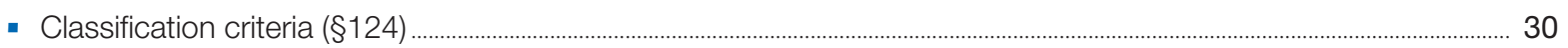

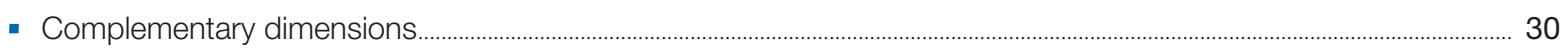


Guidelines for classifying programmes and their related recognised qualifications at ISCED level 1............. 31

- Programmes that span primary education and another ISCED level ..................................................................................... 31

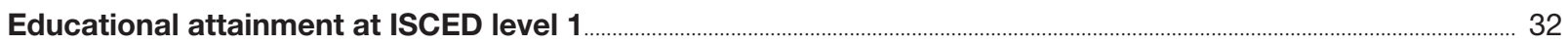

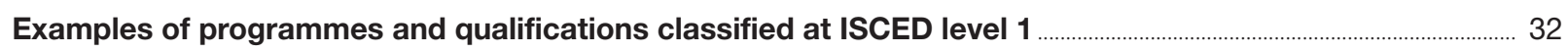

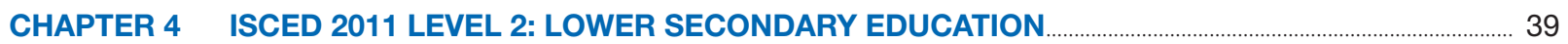

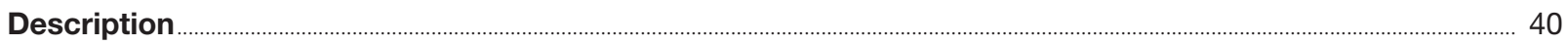

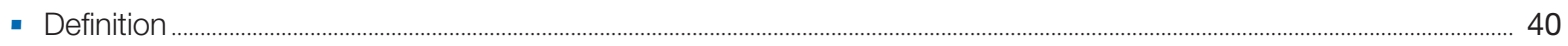

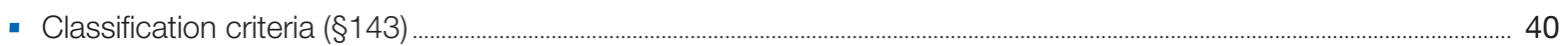

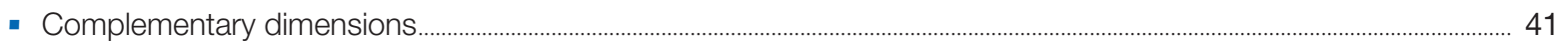

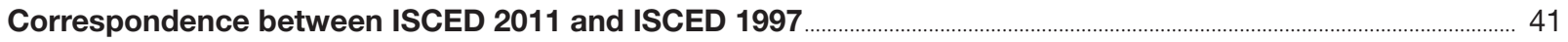

Guidelines for classifying programmes and qualifications at ISCED level 2 .............................................................. 42

- Programmes that span lower secondary education and another ISCED level ............................................................. 42

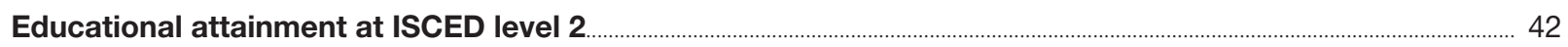

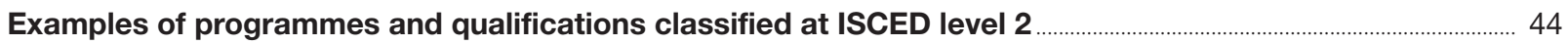

CHAPTER 5 ISCED 2011 LEVEL 3: UPPER SECONDARY EDUCATION ……………................................................. 47

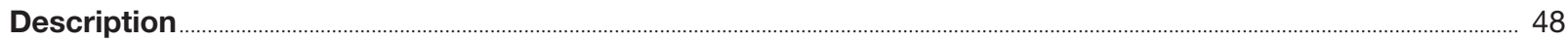

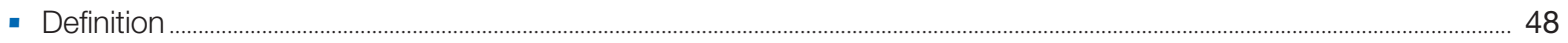

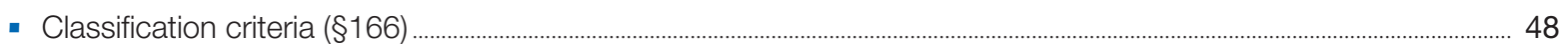

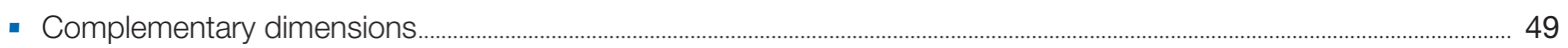

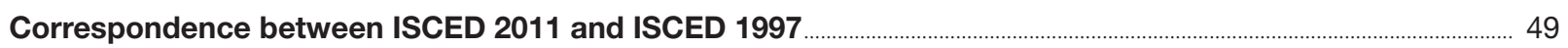

Guidelines for classifying programmes and qualifications at ISCED level 3 …............................................................ 50

- Programmes that span upper secondary education and another ISCED level .............................................................. 51

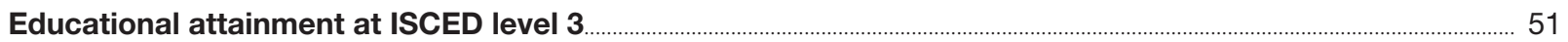

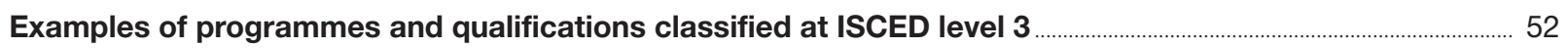

CHAPTER 6 ISCED 2011 LEVEL 4: POST-SECONDARY NON-TERTIARY EDUCATION ……............................. 59

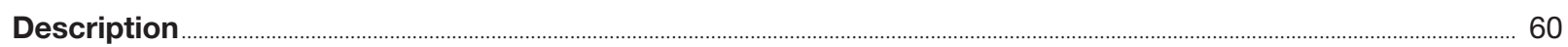

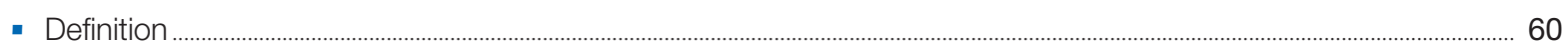

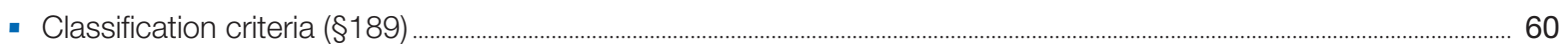

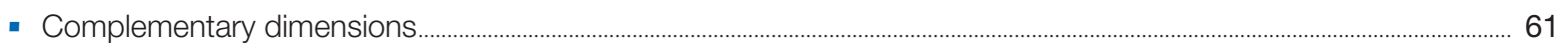

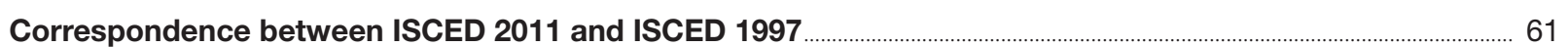

Guidelines for classifying programmes and their related recognised qualifications at ISCED level $4 \ldots \ldots \ldots \ldots . . .62$

- Distinction between ISCED level 4 and ISCED level 5 ............................................................................................................. 63

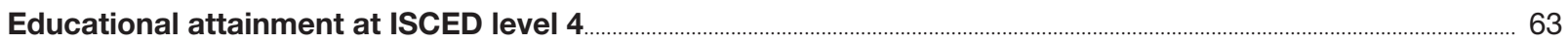

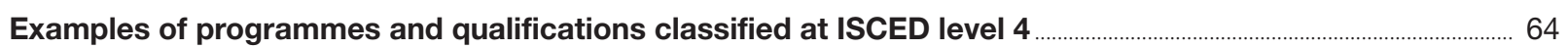

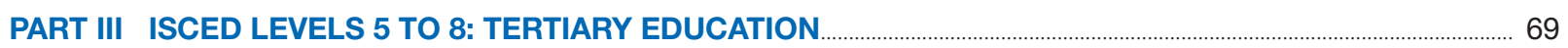

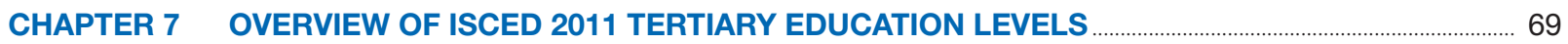

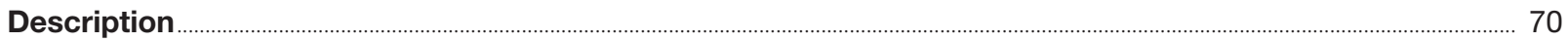

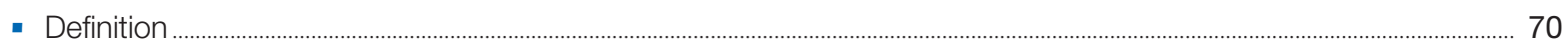

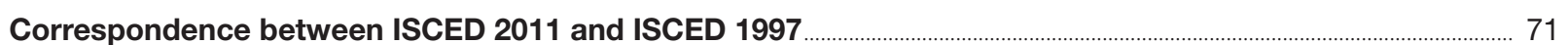


CHAPTER 8 ISCED 2011 LEVEL 5: SHORT-CYCLE TERTIARY EDUCATION ........................................................... 73

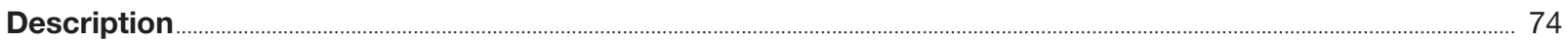

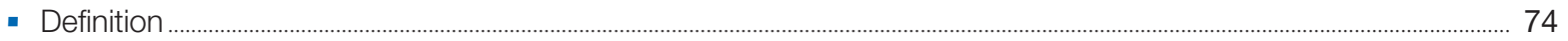

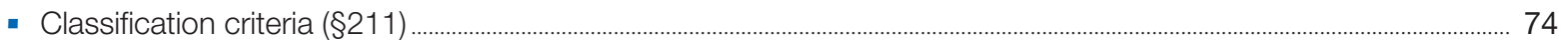

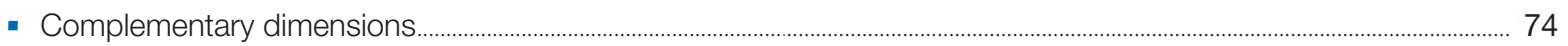

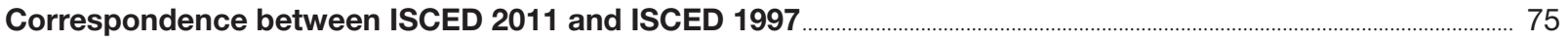

Guidelines for classifying programmes and their related recognised qualifications at ISCED level 5 ............ 75

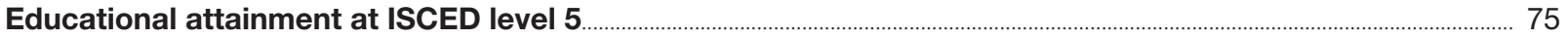

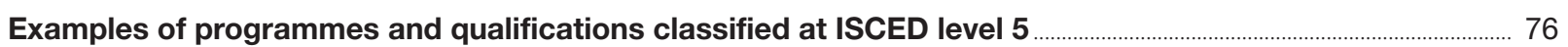

CHAPTER 9 ISCED 2011 LEVEL 6: BACHELOR'S OR EQUIVALENT LEVEL ....................................................... 81

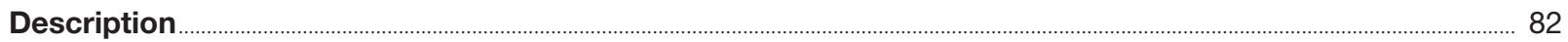

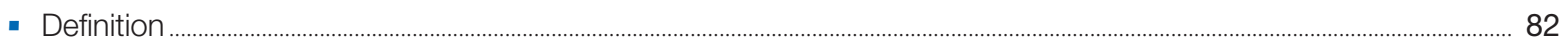

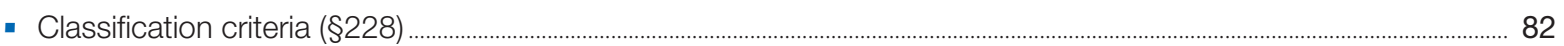

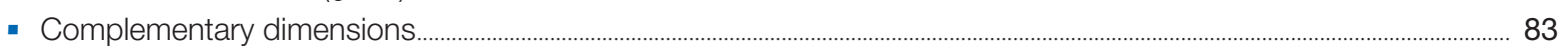

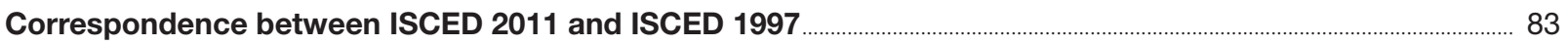

Guidelines for classifying programmes and their related recognised qualifications at ISCED level $6 \ldots \ldots \ldots \ldots . .83$

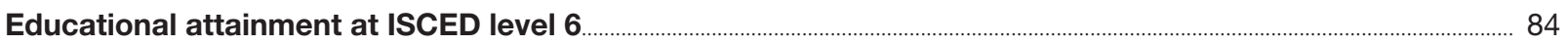

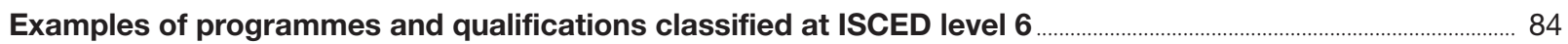

CHAPTER 10 ISCED 2011 LEVEL 7: MASTER'S OR EQUIVALENT LEVEL ..................................................................... 89

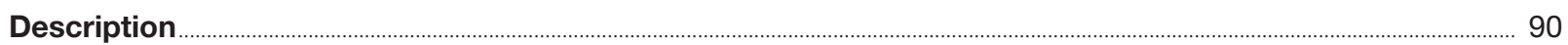

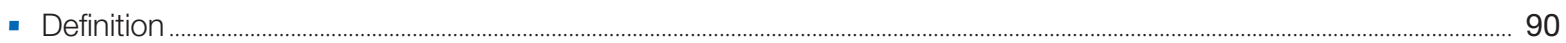

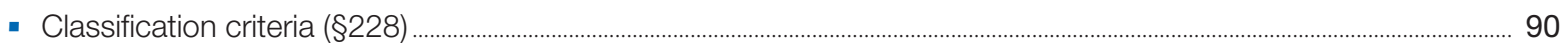

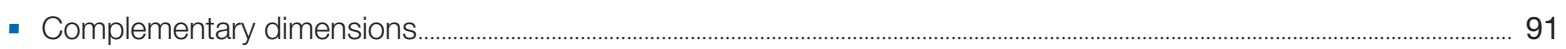

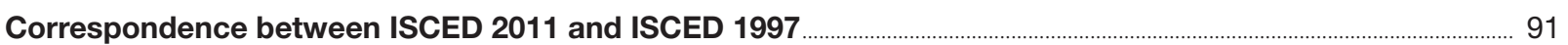

Guidelines for classifying programmes and their related recognised qualifications at ISCED level 7 ............. 91

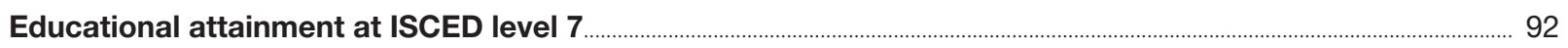

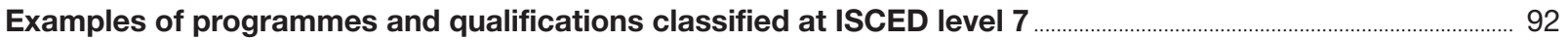

CHAPTER 11 ISCED 2011 LEVEL 8: DOCTORAL OR EQUIVALENT LEVEL ......................................................... 97

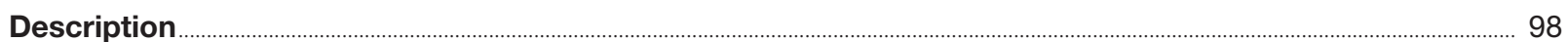

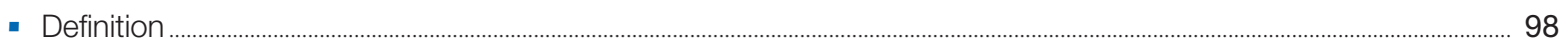

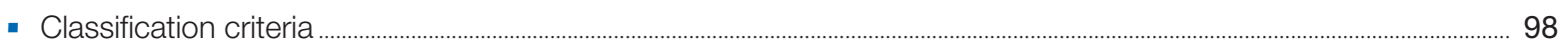

- Complementary dimensions........................................................................................................................................................ 98

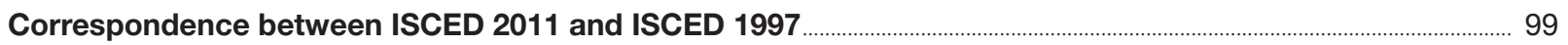

Guidelines for classifying programmes and their related recognised qualifications at ISCED level $8 \ldots \ldots \ldots \ldots . . .99$

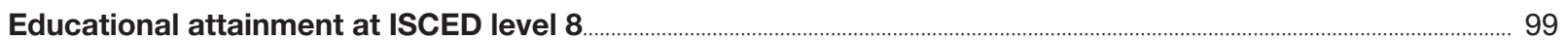

Examples of programmes and qualifications classified at ISCED level 8 …............................................................... 100

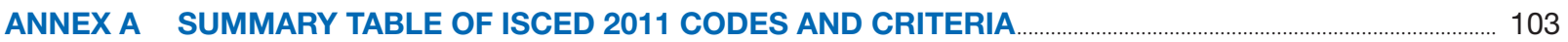

ANNEX B POTENTIAL EDUCATIONAL PATHWAYS IN ISCED 2011

ANNEX C QUICK REFERENCE OF ISCED-P AND ISCED-A CODES IN ISCED 2011 .................................... 113 



\section{Reader's guide}

The ISCED 2011 Operational Manual is intended to assist countries to classify national education programmes and qualifications in their ISCED mappings. The manual will also help users of international statistics to understand which kinds of programmes and qualifications are covered in indicators on education. It provides guidelines and explanatory notes for the interpretation of the revised classification and includes country examples of programmes and related qualifications that have been classified to ISCED 2011.

Where direct text has been quoted in this manual from the official International Standard Classification of Education ISCED 2011 publication (UNESCO-UIS, 2012), a reference to the paragraph number from the ISCED 2011 classification precedes the quote. For example:

(§1) The International Standard Classification of Education (ISCED) is the reference classification for organizing education programmes and related qualifications by education levels and fields.

Where there is a reference to a paragraph number at the end of a text in this manual, it means that this concept is presented in the ISCED 2011 classification itself, but the text of the referred paragraph is not directly quoted. For example:

Early childhood educational development is designed for children aged 0 to 2 years, and pre-primary education

for children from age 3 years to the start of primary education. (\$102)

The ISCED 2011 classification, which contains the definitions of the official framework, is available in the following languages:

Arabic (www.uis.unesco.org/Education/Documents/isced-2011-ar.pdf)

Chinese (www.uis.unesco.org/Education/Documents/isced-2011-ch.pdf)

English (www.uis.unesco.org/Education/Documents/isced-2011-en.pdf)

French (www.uis.unesco.org/Education/Documents/isced-2011-fr.pdf)

Russian (www.uis.unesco.org/Education/Documents/isced-2011-ru.pdf)

Spanish (www.uis.unesco.org/Education/Documents/isced-2011-sp.pdf)

The ISCED 2011 classification also includes an extended glossary of terms related to the classification of educational activities.

- To consult the ISCED 2011 glossary, see Annex VI of the ISCED 2011 classification.

The operational manual has three parts. The first part presents an overview of the revised classification. It also highlights the main changes between ISCED 2011 and ISCED 1997. The second and third parts provide detailed descriptions of each ISCED 2011 level.

In the second and third parts, the chapters on each ISCED level contain general descriptions related to the characteristics of the level, as well as detailed guidelines on the allocation of programmes and related qualifications to ISCED 2011, based on some specific criteria. National examples are provided in order to illustrate the three-digit codes for the parallel classifications of education programmes (ISCED-P) and educational attainment (ISCED-A). Each chapter also includes details on the correspondence between the respective ISCED 2011 and ISCED 1997 levels.

Annex A presents a summary table of all ISCED 2011 codes, including descriptions and criteria. Annex B presents a figure of potential educational pathways in ISCED 2011. Annex C provides a quick cross-reference between ISCED-P and ISCED-A codes. 



\section{PART I \\ ISCED 2011 OVERVIEW}

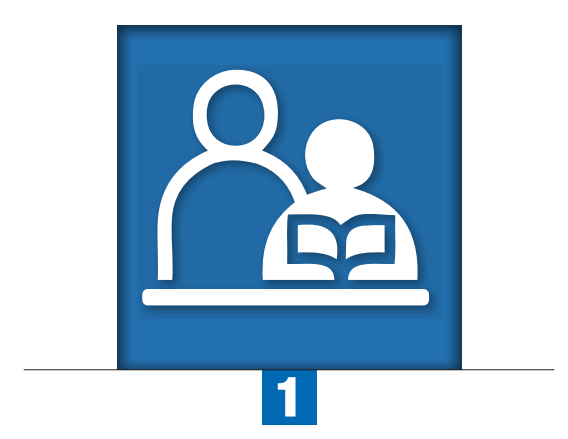

Chapter 1

\section{ISCED 2011 overview}

The International Standard Classification of Education (ISCED) is the reference classification for organising education programmes and related qualifications by education levels and fields. The basic concepts and definitions of ISCED are intended to be internationally valid and comprehensive of the full range of education systems.

ISCED 2011 is the second major revision of this classification (initially developed in the 1970s and first revised in 1997). It was adopted by the UNESCO General Conference in November 2011.

ISCED 2011 presents a revision of the ISCED 1997 levels of education programmes (ISCED-P) and introduces a related classification of educational attainment levels (ISCED-A) based on recognised educational qualifications. Compared to ISCED 1997 which had seven levels of education, ISCED 2011 now has nine levels of education. 


\section{WHAT IS ISCED AND WHAT ARE ITS UNITS OF CLASSIFICATION?}

$(\S 1)^{1}$ The International Standard Classification of Education (ISCED) is the reference classification for organizing education programmes and related qualifications by education levels and fields.

(§2) The basic concepts and definitions of ISCED are therefore intended to be internationally valid and comprehensive of the full range of education systems.

ISCED 2011 is the second major revision of this classification (initially developed in the 1970s and first revised in 1997). The ISCED 2011 classification was adopted by the UNESCO General Conference in November 2011.

\section{- For more general information on ISCED, see Section 1 of the ISCED 2011 classification.}

(§10) The basic units of classification in ISCED are the national (and sub-national) education programme and the related recognized educational qualification.

(§11) In ISCED, an education programme is defined as a coherent set or sequence of educational activities or communication designed and organized to achieve pre-determined learning objectives or to accomplish a specific set of educational tasks over a sustained period.

(§20) Within the context of ISCED, an educational qualification is the official confirmation, usually in the form of a document certifying the successful completion of an education programme or a stage of a programme.

- For more information on ISCED units of classification, see Section 2 of the ISCED 2011 classification.

\section{WHO IS RESPONSIBLE FOR THE ISCED CLASSIFICATION?}

(§91) The UNESCO Institute for Statistics (UIS) is the custodian of ISCED and is thus responsible for the development, maintenance, updating and revision of this reference classification.

(§96) The UIS plans to work closely with countries and partner data collection agencies (including Eurostat and the OECD) to ensure mappings are in accordance with the ISCED classification and updated as needed.

- For more information on ISCED 2011 governance, see Section 8 of the ISCED 2011 classification.

\section{WHAT ARE ISCED MAPPINGS?}

(§8) ISCED mappings are an essential tool for organizing information on national education systems, their programmes and related qualifications in order to ensure the comparability of ISCED-level information and to support their interpretation for international statistical purposes.

(§22) In ISCED, education programmes are classified first and qualifications are subsequently classified. The ISCED mapping is the tool to show the links between education programmes and qualifications.

ISCED mappings for each country help to ensure that international comparisons are more transparent and are better understood by users. Therefore, contextual information presented within mappings is fundamental.

Such information includes, inter alia, national names of programmes, theoretical entrance ages and durations of programmes, minimum entry requirements and qualifications received upon successful completion of programmes. This information is presented alongside relevant ISCED dimensions such as the ISCED level, orientation of the programme, completion and access sub-categories, and, at Bachelor's and Master's levels, the position in the national degree structure. 
The classification of national programmes to ISCED levels and complementary dimensions can then be used to determine the three-digit ISCED-P code of a programme and corresponding three-digit ISCED-A code related to the qualification received upon successful completion of the programme.

ISCED mappings may also include some notes with further explanatory details regarding the national programmes.

\section{WHAT IS COVERED AND NOT COVERED BY THE ISCED 2011 CLASSIFICATION?}

(§35) ISCED 2011 covers formal and non-formal education programmes offered at any stage of a person's life. Qualifications which are recognized by the relevant national authorities, however they are obtained (e.g. by successful completion of a formal education programme or via a non-formal education programme or informal learning activity), are used for the purpose of measuring educational attainment. ISCED does not cover programmes of informal, incidental or random learning, nor qualifications which are not recognized.

(§42) In ISCED 2011, there is a clear distinction between formal and non-formal education for statistical purposes. Currently, international data collection exercises on education (mappings, surveys, censuses, etc.) are mainly focused on formal education.

While in the scope of ISCED, information on non-formal education programmes is not usually included in international collections of education statistics. However, for the purposes of educational attainment, recognised qualifications obtained from non-formal education programmes are usually taken into account, if these are considered equivalent to the qualifications obtained in formal education.

- For more information on the scope of education in ISCED, see Section 4 of the ISCED 2011 classification.

- For more information and details on issues regarding non-formal education, see Section 4 and Annex $V$ of the ISCED 2011 classification.

\section{WHAT ARE THE LEVELS OF EDUCATION WITHIN THE ISCED 2011 CLASSIFICATION?}

(§45) The main cross-classification variables of ISCED are levels and fields of education.

This operational manual focuses on the classification of programmes and related qualifications by ISCED 2011 levels.

ISCED 2011 has nine levels of education, from level 0 to level 8:

- ISCED 0: Early childhood education

- ISCED 1: Primary education

- ISCED 2: Lower secondary education

- ISCED 3: Upper secondary education

- ISCED 4: Post-secondary non-tertiary education

- ISCED 5: Short-cycle tertiary education

- ISCED 6: Bachelor's or equivalent level

- ISCED 7: Master's or equivalent level

- ISCED 8: Doctoral or equivalent level

(§47) The ISCED level reflects the degree of complexity and specialisation of the content of an education programme, from foundational to complex.

(§48) The more advanced the programme, the higher the level of education.

For more information on ISCED levels, see Sections 5 and 9 of the ISCED 2011 classification. 


\section{HOW ARE PROGRAMMES AND RELATED QUALIFICATIONS ALLOCATED TO THE ISCED 2011 LEVELS?}

(§50) The classification of education programmes by levels aims to reflect their content. Due to the absence of direct measures to classify educational content, ISCED employs proxy criteria that help to classify a given education programme to the appropriate ISCED level.

(§51) These proxy criteria are comprised of main and subsidiary criteria.

For example, proxy measures that can be used in the classification of programmes to levels are the duration and cumulative duration of programmes within and across ISCED levels. ISCED 2011 provides some guidelines of typical duration and ranges of cumulative duration as criteria for classifying education programmes by level. These criteria are summarised in Tables 1.1 and 1.2.

- Table 1.1 -

\section{Duration by ISCED level}

\begin{tabular}{|c|c|}
\hline ISCED level & Typical duration [most common duration] \\
\hline 0 & $\begin{array}{l}\text { No duration criteria. However, a programme should account for at least the equivalent of } 2 \text { hours per day } \\
\text { and } 100 \text { days a year of educational activities in order to be included. }\end{array}$ \\
\hline 1 & 4 to 7 years [most common: 6 years] \\
\hline 2 & 2 to 5 years [most common: 3 years] \\
\hline 3 & 2 to 5 years [most common: 3 years] \\
\hline 4 & 6 months to 2 or 3 years \\
\hline 5 & 2 to 3 years \\
\hline 6 & $\begin{array}{l}3 \text { to } 4 \text { years when directly following ISCED level } 3 \text {; or } \\
1 \text { to } 2 \text { years when following another ISCED level } 6 \text { programme }\end{array}$ \\
\hline 7 & $\begin{array}{l}1 \text { to } 4 \text { years when following ISCED level } 6 \text {; or } \\
5 \text { to } 7 \text { years when directly following ISCED level } 3\end{array}$ \\
\hline 8 & Minimum 3 years \\
\hline
\end{tabular}

- Table 1.2 -

Typical cumulative duration in primary and secondary education

\begin{tabular}{l|l}
\hline ISCED level & Range [most common cumulative duration] \\
\hline 1 & 4 to 7 years [most common: 6 years] \\
\hline $1+2$ & 8 to 11 years [most common: 9 years] \\
\hline $1+2+3$ & 11 to 13 years [most common: 12 years] \\
\hline
\end{tabular}

Other proxy criteria exist within ISCED 2011, such as requirements to enter the programme, type of teacher qualifications, organisation of instruction and design of the programme (for example, to prepare for entry to the labour market or to other education programmes).

The providers of education programmes should not be used as a main criterion for classifying programmes by ISCED level. The primary criterion is the complexity and specialisation of a programme's educational content and how the content is reflected in the classification criteria $(\$ 52)$.

- For more information on ISCED 2011 duration and cumulative duration criteria, see Section 5 and Table 21 in the ISCED 2011 classification. 
(§49) Classifying education programmes into a progression of levels aims to reflect the full range of educational pathways available in education systems. Most education systems provide several possible pathways from ISCED level 0/1 to 8.

- To see possible educational pathways by ISCED 2011 categories, see Figure 2 in Annex I of the ISCED 2011 classification and Annex B in this operational manual.

\section{HOW ARE PROGRAMMES THAT SPAN ISCED LEVELS, ARE SEQUENTIAL OR ARE COMPRISED OF MODULES CLASSIFIED WITHIN ISCED 2011?}

(§26) When classifying national education programmes by ISCED levels, transition points between national programmes and exit points into the labour market may not always coincide with transition points between ISCED levels. Three such cases can be identified: i) programmes that span two or more ISCED levels; ii) two or more sequential programmes that together constitute one ISCED level; and iii) programmes which are provided in modules or courses without clearly defined sequencing.

For programmes that span two or more ISCED levels, the years, grades or stages that meet the criteria for each ISCED level should be assigned accordingly to the different levels. Transition points already existing in the programmes may be used to help identify the boundary between ISCED levels.

Where two or more sequential programmes constitute one ISCED level, special care should be taken in reporting statistics. For example, while enrolment would be combined for all programmes in the level, data on entrants would only include those entering the first programme in the level. Furthermore, data on graduates would be only those completing the final programme in the sequence within the level (except where successful completers of programmes leading to partial level completion are also collected). (§32)

Programmes composed of modules also need to be carefully assessed in order to ensure that they meet all the criteria for an education programme within ISCED 2011 and also be given special consideration in the reporting of data.

- For more information on programmes spanning ISCED levels, sequential programmes and modular programmes, see Section 3 in the ISCED 2011 classification.

\section{BY WHAT COMPLEMENTARY DIMENSIONS CAN PROGRAMMES AND QUALIFICATIONS BE FURTHER CLASSIFIED WITHIN ISCED 2011 LEVELS?}

(§45) Within ISCED levels, programmes and qualifications are further classified by complementary dimensions. These include:

- Programme orientation;

- Completion of the ISCED level;

- Access to higher ISCED levels; and

- Position in the national degree and qualification structure.

For ISCED levels 2 to 5, there are two possible programme orientations: general and vocational. ISCED 2011 also allows for the possibility of coding academic and professional orientation categories at the tertiary levels (5 to 8). However, in the absence of internationally-agreed definitions on these orientation categories for tertiary education, the category "unspecified" may be used in international statistics for ISCED levels 6 to 8.

ISCED 2011 introduces a new complementary dimension: completion of an ISCED level and access to higher levels of education. Altogether there are four possible sub-categories of programmes (although not all four apply to all levels):

- No level completion - and thus without direct access to a higher ISCED level (which in the case of ISCED level 3 is to levels 5,6 or 7 ); 
- Partial level completion without direct access to a higher ISCED level;

- Level completion without direct access to a higher ISCED level;

- Level completion with direct access to a higher ISCED level (which in the case of ISCED level 3 is to first tertiary programmes at levels 5,6 or 7 ).

Programmes at ISCED levels 6 and 7 can be further categorised by the position in the national degree and qualification structure (see the respective chapters for more information on these sub-categories).

Not all complementary dimensions apply to all levels. In addition, ISCED level 0 is further sub-divided according to the type of programme and age group into early childhood educational development and pre-primary education.

- For more information on ISCED 2011 complementary dimensions, see Section 5 of the ISCED 2011 classification.

\section{FIELDS OF EDUCATION AND TRAINING}

Within ISCED, programmes and related qualifications can be classified by fields of education and training as well as by levels. The ISCED 2011 revision focused on ISCED levels and complementary dimensions related to ISCED levels.

Following the adoption of ISCED 2011, a separate review and global consultation process took place on the ISCED fields of education. The ISCED fields were revised, and the UNESCO General Conference adopted the ISCED 2013 Fields of Education and Training classification (ISCED-F 2013) in November 2013 at its 37th session.

The ISCED 2013 Fields of Education and Training classification (UNESCO-UIS, 2014) is available in the following languages:

Arabic (www.uis.unesco.org/Education/Documents/isced-fields-of-education-training-2013AR.pdf)

Chinese (www. uis.unesco.org/Education/Documents/isced-fields-of-education-training-2013CH.pdf)

English (www.uis.unesco.org/Education/Documents/isced-fields-of-education-training-2013.pdf)

French (www.uis.unesco.org/Education/Documents/isced-fields-of-education-training-2013FR.pdf)

Russian (www.uis.unesco.org/Education/Documents/isced-fields-of-education-training-2013RU.pdf)

Spanish (www.uis.unesco.org/Education/Documents/isced-fields-of-education-training-2013ES.pdf)

\section{WHAT ARE THE CODING SCHEMES WITHIN ISCED 2011?}

(§89) The ISCED classification consists of parallel coding schemes for education programmes (ISCED Programmes or ISCED-P) and levels of educational attainment (ISCED-Attainment or ISCED-A). Three-digit coding systems are used to codify both education programmes and educational attainment.

It should be underlined that, while there is very often a correspondence between the ISCED-P code of a programme and the ISCED-A code resulting from its successful completion, ISCED-A codes cannot always be translated automatically from ISCED-P codes. For example, certain education programmes may lead to more than one qualification, each of which may result in different educational attainment levels. The programme itself will be classified in ISCED-P according to the highest completion and access category to which it leads, but each resulting qualification will be classified in ISCED-A according to the actual educational attainment level with which it is associated.

Codes ending in "1" in ISCED-P (for programmes which are insufficient for level completion) do not exist in ISCED-A since educational attainment from such programmes is coded at the ISCED level below the programme of study.

- For more information on ISCED 2011 coding, see Tables 1-3 and Annexes II and III in the ISCED 2011 classification. Also see Annexes $A$ and $C$ in this operational manual. 


\section{COMPARISON OF ISCED 2011 WITH ISCED 1997}

\section{Major changes between ISCED 2011 and ISCED 1997}

ISCED 2011 presents a revision of the ISCED 1997 levels of education programmes (ISCED-P) and introduces a related classification of educational attainment levels (ISCED-A) based on recognised educational qualifications.

ISCED 2011 includes improved definitions of formal and non-formal education, educational activities and programmes. An expanded glossary is also included to assist users in understanding specific terms related to ISCED.

Compared to ISCED 1997 which had seven levels of education, ISCED 2011 now has nine levels of education. Tertiary education has been restructured, taking into account changes in higher education such as the Bologna structure, and now comprises four levels of education compared with two levels in ISCED 1997. Programmes previously classified in level 5 of ISCED 1997 will now be allocated to levels 5, 6 or 7 in ISCED 2011. As well, ISCED level 0 has been expanded to include a new category covering early childhood educational development programmes designed for children under the age of 3 years. Each education level within ISCED has also been more clearly delineated, which may result in some changes of classification for programmes that previously sat on the border between ISCED levels (for example, between ISCED levels 3 and 4).

ISCED 2011 comprises two parallel classifications, ISCED-P and ISCED-A, each represented by a separate but similar three-digit coding scheme.

The complementary dimensions within ISCED levels have also been revised. There are now only two categories of orientation: general and vocational. Programmes previously classified as pre-vocational (in ISCED 1997) do not provide labour market-relevant qualifications and are now mainly classified as general education (§278). ISCED 2011 also proposes codes for 'academic' and 'professional' orientations at the tertiary level. However as there is still a need for international agreement on their definitions, the code 'orientation unspecified' is also available for use at ISCED 2011 levels 6 to 8.

ISCED 1997 differentiated access to education at higher ISCED levels in two categories depending on the type of subsequent education, while ISCED 2011 identifies only one group of programmes that provide access to higher education levels. The ISCED 2011 sub-category "level completion with access to higher ISCED levels" corresponds to the combined destination categories A and B in ISCED 1997. ISCED 2011 further sub-classifies programmes which do not provide access to higher ISCED levels into the sub-categories: "no level completion", "partial level completion" and "level completion". These three sub-categories in ISCED 2011 correspond to destination category C in ISCED 1997. (§278)

Moreover, while the position in the national degree structure of tertiary programmes was mentioned in ISCED 1997, specific coding for this dimension has been introduced in ISCED 2011 for levels 6 and 7 (Bachelor's or equivalent and Master's or equivalent levels respectively).

\section{Correspondence tables between ISCED revisions}

The correspondence between the levels in ISCED 2011 and ISCED 1997 is shown in Table 1.3.

- Table 1.3 .

Comparison of levels of education between ISCED 2011 and ISCED 1997

\begin{tabular}{|c|c|c|c|}
\hline \multicolumn{2}{|c|}{ ISCED 2011} & \multicolumn{2}{|c|}{ ISCED 1997} \\
\hline 01 & Early childhood educational development & & - \\
\hline 02 & Pre-primary education & 0 & Pre-primary education \\
\hline 1 & Primary education & 1 & Primary education or first stage of basic education \\
\hline 2 & Lower secondary education & 2 & $\begin{array}{l}\text { Lower secondary education or second stage of basic } \\
\text { education }\end{array}$ \\
\hline 3 & Upper secondary education & 3 & (Upper) secondary education \\
\hline 4 & Post-secondary non-tertiary education & 4 & Post-secondary non-tertiary education \\
\hline 5 & Short-cycle tertiary education & \multirow[t]{3}{*}{5} & \multirow{3}{*}{$\begin{array}{l}\text { First stage of tertiary education (not leading directly } \\
\text { to an advanced research qualification) (5A, 5B) }\end{array}$} \\
\hline 6 & Bachelor's or equivalent level & & \\
\hline 7 & Master's or equivalent level & & \\
\hline 8 & Doctoral or equivalent level & 6 & $\begin{array}{l}\text { Second stage of tertiary education (leading to an } \\
\text { advanced research qualification) }\end{array}$ \\
\hline
\end{tabular}


Table 1.4 shows the correspondence between the complementary dimensions of ISCED 2011 and ISCED 1997.

- Table 1.4 -

Comparison of complementary dimensions between ISCED 2011 and ISCED 1997

\begin{tabular}{|c|c|c|c|c|c|}
\hline \multicolumn{3}{|c|}{ ISCED 2011} & \multicolumn{3}{|c|}{ ISCED 1997} \\
\hline \multicolumn{2}{|c|}{$\begin{array}{l}\text { Orientation } \\
\text { (second-digit code) }\end{array}$} & $\begin{array}{l}\text { Levels } \\
\text { applied }\end{array}$ & \multicolumn{2}{|c|}{ Orientation } & $\begin{array}{l}\text { Levels } \\
\text { applied }\end{array}$ \\
\hline \multirow[t]{2}{*}{4} & \multirow[t]{2}{*}{ General education } & \multirow[t]{3}{*}{2 to 5} & G & General education & \multirow[t]{3}{*}{2 to 4} \\
\hline & & & $\mathrm{P}$ & Pre-vocational or pre-technical education & \\
\hline 5 & Vocational education & & V & Vocational or technical education & \\
\hline 4 & Academic education* & 5 to 8 & & - & \\
\hline 5 & Professional education* & 5 to 8 & & - & \\
\hline 6 & Unspecified orientation* & 6 to 8 & & - & \\
\hline \multicolumn{2}{|c|}{$\begin{array}{l}\text { Completion and access } \\
\text { (third-digit ISCED-P code) }\end{array}$} & $\begin{array}{l}\text { Levels } \\
\text { applied }\end{array}$ & \multicolumn{2}{|c|}{ Destination } & $\begin{array}{l}\text { Levels } \\
\text { applied }\end{array}$ \\
\hline \multirow[t]{5}{*}{4} & \multirow[t]{5}{*}{$\begin{array}{l}\text { Sufficient for completion of the level with } \\
\text { direct access to the higher ISCED level }\end{array}$} & \multirow[t]{5}{*}{2 to 8} & \multirow[t]{2}{*}{ A } & $\begin{array}{l}\text { Programmes designed to lead to "A" } \\
\text { programmes at the higher ISCED level } \\
\text { (on a direct pathway to doctoral studies) }\end{array}$ & 2 to 4 \\
\hline & & & & $\begin{array}{l}\text { Theoretically-based programmes at first } \\
\text { tertiary level }\end{array}$ & 5 \\
\hline & & & \multirow[t]{3}{*}{ B } & $\begin{array}{l}\text { Programmes designed to lead to "B" } \\
\text { programmes at the higher ISCED level } \\
\text { (on a pathway to the labour market) }\end{array}$ & $2,3,\left(4^{* *}\right)$ \\
\hline & & & & $\begin{array}{l}\text { Programmes designed to lead to the } \\
\text { labour market }\end{array}$ & $4^{\star *}$ \\
\hline & & & & $\begin{array}{l}\text { Practically-oriented/occupationally- } \\
\text { specific programmes at first tertiary level }\end{array}$ & 5 \\
\hline 3 & $\begin{array}{l}\text { Sufficient for completion of the level } \\
\text { without direct access to the higher ISCED } \\
\text { level }\end{array}$ & 2 to 4 & \multirow[t]{3}{*}{$\mathrm{C}$} & \multirow[t]{3}{*}{$\begin{array}{l}\text { Programmes designed to lead to the } \\
\text { labour market without direct access to } \\
\text { the higher ISCED level }\end{array}$} & \multirow[t]{3}{*}{$2,3,\left(4^{\star *}\right)$} \\
\hline 2 & $\begin{array}{l}\text { Partial completion of the level without } \\
\text { direct access to the higher ISCED level }\end{array}$ & 2,3 & & & \\
\hline 1 & $\begin{array}{l}\text { Insufficient for completion of the level } \\
\text { without direct access to the higher ISCED } \\
\text { level }\end{array}$ & 2 to 8 & & & \\
\hline \multicolumn{2}{|c|}{$\begin{array}{l}\text { Position in the national degree structure } \\
\text { (third-digit ISCED-P code) }\end{array}$} & $\begin{array}{l}\text { Levels } \\
\text { applied }\end{array}$ & & & \\
\hline 5 & First degree & 6 & - & - & - \\
\hline 6 & Long first degree & 6,7 & - & - & - \\
\hline 7 & $\begin{array}{l}\text { Second or further degree following } \\
\text { a Bachelor's or equivalent programme }\end{array}$ & 6,7 & - & - & - \\
\hline 8 & $\begin{array}{l}\text { Second or further degree following } \\
\text { a Master's or equivalent programme }\end{array}$ & 7 & - & - & - \\
\hline
\end{tabular}

* In the absence of internationally-agreed definitions for academic and professional orientations at the tertiary level, 'general' or 'vocational' will be used at ISCED 2011 levels 2 to 5, and 'orientation unspecified' may be used at ISCED 2011 levels 6 to 8 .

** Destination C in ISCED 1997 was introduced at ISCED level 4 for UOE countries (UNESCO-OECD-Eurostat data collection). For other countries, only destinations A and B applied at ISCED 1997 level 4.

- For more details on the correspondence between ISCED 2011 and ISCED 1997 levels, see Section 10 and Tables 19, 20 and 21 of the ISCED 2011 classification.

\section{Note}

1. Paragraph numbers are references to the main ISCED 2011 classification document. See more details in the Reader's Guide. 


\section{PART II \\ ISCED 2011 LEVELS 0 TO 4: \\ FROM EARLY CHILDHOOD EDUCATION \\ TO POST-SECONDARY NON-TERTIARY EDUCATION}

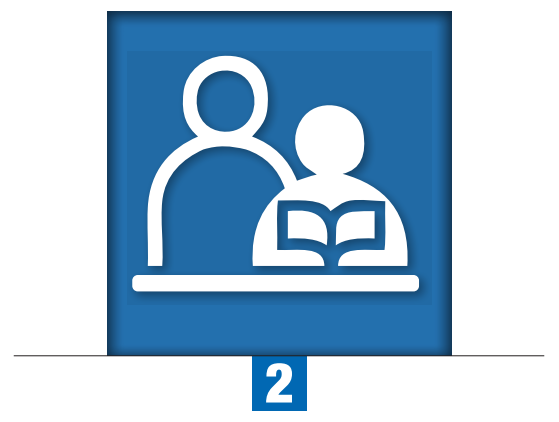

Chapter 2

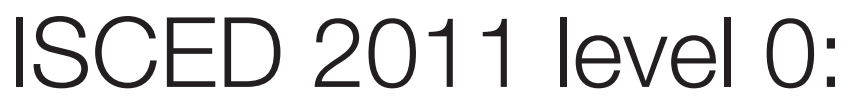

\section{Early childhood education}

ISCED level 0 refers to early childhood programmes that have an intentional education component. ISCED level 0 programmes target children below the age of entry into primary education (ISCED level 1). These programmes aim to develop cognitive, physical and socio-emotional skills necessary for participation in school and society.

Programmes classified at ISCED level 0 may be referred to in many ways, for example: early childhood education and development, play school, reception, pre-primary, pre-school or educación inicial. For programmes provided in crèches, daycare centres, nurseries or guarderías, it is important to ensure that they meet the ISCED level 0 classification criteria specified. For international comparability purposes, the term 'early childhood education' is used to label ISCED level 0. 


\section{DESCRIPTION}

\section{Definition}

$(\S 100)^{1}$ Programmes at ISCED level 0 are typically designed with a holistic approach to support children's early cognitive, language, physical, social and emotional development and introduce young children to organized instruction outside of the family context. ISCED level 0 refers to early childhood programmes that have an intentional education component.

(§101) At this level, programmes are not necessarily highly structured but are designed to provide an organized and purposeful set of learning activities in a safe physical environment. They allow children to learn through interaction with other children under the guidance of staff/educators, typically through creative and play-based activities.

(§102) ISCED level 0 programmes target children below the age of entry into ISCED level 1. There are two categories of ISCED level 0 programmes: early childhood educational development and pre-primary education. The former has educational content designed for younger children (in the age range of 0 to 2 years), whilst the latter is typically designed for children from age 3 years to the start of primary education.

\section{Classification criteria}

\section{Main criteria}

a. Educational properties of the programme

(§105) The educational properties of early childhood educational development [ISCED-P 010] are characterised by a learning environment that is visually stimulating and language-rich. These programmes foster self-expression with an emphasis on language acquisition and the use of language for meaningful communication. There are opportunities for active play, so that children can exercise their coordination and motor skills under supervision and through interaction with staff.

(§106) The educational properties of pre-primary education [ISCED-P 020] are characterised by interaction with peers and educators, through which children improve their use of language and social skills, start to develop logical and reasoning skills, and talk through their thought processes. They are also introduced to alphabetical and mathematical concepts, and encouraged to explore their surrounding world and environment. Supervised gross motor activities (i.e. physical exercise through games and other activities) and play-based activities can be used as learning opportunities to promote social interactions with peers and to develop skills, autonomy and school readiness.

b. Institutional context

(§107) ISCED level 0 programmes are usually school-based or otherwise institutionalised for a group of children (e.g. centre-based, community-based, home-based). ISCED level 0 excludes purely family-based arrangements that may be purposeful but are not organized in a "programme" (e.g. informal learning by children from their parents, other relatives or friends is not included under ISCED 0).

c. Typical target age of children for whom the programme is designed

(\$108) Within ISCED 0, early childhood educational development programmes are targeted at children aged 0 to 2 years; and pre-primary education programmes are targeted at children aged 3 years until the age to start ISCED 1. The upper age limit for the pre-primary education category depends in each case on the theoretical age of entry into ISCED level 1, i.e. primary education. 
d. Programme intensity/duration

(§110) ISCED recommends the following minimum intensity and duration to improve cross-national comparability: education programmes must account for at least the equivalent of 2 hours per day and 100 days a year of educational activities in order to be classified in ISCED.

\section{Subsidiary criteria}

a. Staff pedagogical qualifications

(§111) Where appropriate, the requirement of pedagogical qualifications for educators is a good proxy criterion for an education programme in those education systems in which such a requirement exists. It serves to distinguish early childhood education from childcare for which no explicitly pedagogically-trained staff is required.

b. Existence of a regulatory framework

(§112) Where relevant, the existence of a reference or regulatory framework issued or recognized by relevant national authorities (e.g. a ministry of education, other relevant ministry or affiliated institution) is a good proxy criterion for an education programme. This would include guidelines, standards or instructions that describe the learning opportunities provided to young children.

c. Typically not part of compulsory education

(§113) In education systems that have compulsory schooling, non-compulsory education programmes which are designed to take place before the start of compulsory education and which fulfil the criteria above are classified as ISCED level O. In addition, in some countries the first stage or cycle of compulsory education may also be classified at ISCED level 0 if it fulfils the criteria at this level. Thus, the beginning of compulsory education is not a sufficient criterion to distinguish ISCED level 0 programmes from ISCED level 1 programmes, even though this may be the case in some education systems.

\section{Complementary dimensions}

(§116) One dimension differentiates education programmes at ISCED level 0:

- Target age group

Early childhood education programmes target young children below the age of entry into ISCED level 1. Early childhood educational development is designed for children aged 0 to 2 years, and pre-primary education for children from age 3 to the start of primary education. $(\S 102)$

\section{CORRESPONDENCE BETWEEN ISCED 2011 AND ISCED 1997}

(§275) In ISCED 2011, level 0 covers early childhood education for all ages, including very young children. Programmes are sub-classified into two categories depending on the level of complexity of the educational content: early childhood educational development (code 010) and pre-primary education (code 020). Early childhood educational development programmes (code 010) are generally designed for children younger than 3 years. It is introduced as a new category in ISCED 2011 and is not covered by ISCED 1997. Pre-primary education (code 020) corresponds exactly to level O in ISCED 1997. 


\section{GUIDELINES FOR CLASSIFYING PROGRAMMES AND THEIR RELATED RECOGNISED QUALIFICATIONS AT ISCED LEVEL 0}

ISCED level 0 refers to early childhood programmes that have an intentional education component. ISCED level 0 programmes target children below the age of entry into ISCED level 1. These programmes aim to develop cognitive, physical and socio-emotional skills necessary for participation in school and society. $(\$ 100,102)$

Programmes offered at ISCED level 0 are often differentiated by age. There are two categories of ISCED level 0 programmes: ISCED 010 - early childhood educational development and ISCED 020 - pre-primary education. ISCED 010 has intentional educational content designed for younger children (typically in the age range of 0 to 2 years) (Examples Group 1), whilst ISCED 020 is typically designed for children from the age of 3 years to the start of primary education (ISCED level 1) (§108) (Examples Group 2).

Some ISCED level 0 programmes span the two categories of ISCED level 0 (i.e. education programmes for very young children up to the start of ISCED level 1). These integrated early childhood education programmes need special consideration for classification. Programmes divided into years, stages or cycles should be sub-divided into the two categories based primarily on the educational properties of the programme (see main criteria). Where no sub-division of the programme exists, classification into the two categories should be based on the ages of the participants. (§109) For data reporting purposes, data for children below 3 years of age in such integrated programmes should be reported as ISCED 010; data for children aged 3 and older should be reported as ISCED 020 (Examples Group 3).

Particular care should be taken in the classification of home-based programmes. For examples of home-based early childhood programmes that should and should not be considered as ISCED level 0, see Examples Group 4 and Examples Group 5 respectively.

Similarly, programmes providing only childcare (i.e. supervision, nutrition and health) are not covered by ISCED level 0. Where both education and non-education programmes exist in a country and it is possible to enrol in each independently, only the education programmes should be classified as ISCED level 0 . However, it should be noted that it is acceptable to consider early childhood programmes including both education and childcare components for classification at ISCED level 0 where the non-education portion is greater than the education portion, so long as the education portion meets the other criteria described above including the minimum intensity and duration criteria.

Along with an intentional child-development and educational focus, a key defining factor of ISCED level 0 programmes is the sustained intensity and duration of planned educational activities. These are what differentiate ISCED level 0 from other early childhood programmes, such as childcare and occasional, after-hours or vacation care. It is expected that children enrolled in an ISCED level 0 programme will receive a sustained learning experience with the features of continuity and duration of intentional educational activities. Where the other main criteria (and if applicable also the subsidiary criteria) have been met, to be classified at ISCED level 0 the intentional educational component of the programme must represent the equivalent of at least 2 hours per day in intensity and a duration of at least 100 days a year. Note that this is a minimum intensity and duration and it is possible for both the intentional educational portion of programmes and the programmes themselves to exceed this.

Care should be taken to distinguish between the intensity/duration of the intentional educational components of ISCED level 0 programmes, the expected intensity/duration of attendance of enrolled children and the opening hours of the institutions which provide the programmes, as they are not necessarily the same.

If a programme meets the main criteria for ISCED level 0 and children enrolled in the programme are expected to experience intentional educational activities for at least the intensity/duration specified, the programme may in its entirety be deemed an education programme within ISCED 2011. This includes cases where a programme includes additional activities that are not specifically educationally-focussed, as long as the programme meets the minimum intensity/ duration of intentional educational activities.

Where exact information on the intensity and duration of a programme's intentional educational components are not available, institution opening hours or programme delivery hours should not be used as a proxy to determine a 
programme's inclusion in ISCED level 0. In these cases, an estimate of the typical or intended intensity/duration of the programme's intentional educational properties should be used.

Programmes should be excluded from ISCED level 0 if the expected attendance of enrolled children is less than the minimum intensity and duration criteria, regardless of both the hours or days that the programme is available or the intensity/duration of the provision of intentional educational content (Examples Group 5).

Typical examples of programmes to be excluded from ISCED level 0 because the expected attendance of enrolled children does not meet the minimum intensity and duration criteria include:

- programmes where attendance can be ad hoc or of a drop-in style where individual children will not experience a continuity of structured learning opportunities;

- short-duration programmes, such as vacation, care which may have an educational component but not a sustained period of instruction or learning opportunities; and

- programmes with intentional educational properties but with no minimum level of attendance, such as where parents are free to choose an intensity and duration of their child's attendance that does not meet the minimum ISCED level 0 intensity and duration criteria.

The beginning of compulsory education is not a sufficient criterion to distinguish ISCED level 0 programmes from ISCED level 1 programmes, even though this may be the case in some education systems.

ISCED level 0 includes programmes for children with special educational needs corresponding to the criteria for this level, irrespective of their ages (\$117). Organised instruction for children with special educational needs should be included at this level if either the participants are of a similar age to other students enrolled in early childhood educational development or pre-primary education or if the instructional content is at a significantly lower level than that of the first years of primary education (even if students are not of the typical age for ISCED level 0). This may include, in particular, education provided in hospitals or in special schools or training centres.

\section{Programmes that span ISCED levels 0 and 1}

Education programmes spanning ISCED levels 0 and 1 need special consideration for classification. In education systems where the national programme of primary education also includes some early childhood education, only those grades, stages or cycles that correspond to the criteria for the respective levels (ISCED 0 or 1 ) should be attributed to those levels. (\$114)

If use of the classification criteria does not result in a clear boundary between ISCED levels 0 and 1 , the following is recommended: (\$115)

i) for programmes spanning ISCED levels 0 and 1 that are organised in stages, the end of the stage closest to six years of age should be used as the transition point between ISCED levels 0 and 1; and

ii) for programmes spanning ISCED levels 0 and 1 that are not divided into stages, grades targeting children under the age of 6 should be classified as ISCED level 0, while the remaining years should be classified as ISCED level 1.

\section{EDUCATIONAL ATTAINMENT AT ISCED LEVEL 0}

(§119) For classifying educational attainment, level 0 (less than primary education) is used for individuals who:

- never attended an education programme (ISCED-A 010);

- attended some early childhood education (ISCED-A 020); or

- attended some primary education but have not successfully completed ISCED level 1 (with or without having attended ISCED 0) (ISCED-A 030).

The ISCED-A code "020" includes those who have attended either an early child educational development or pre-primary education programme, or both. 


\section{EXAMPLES OF PROGRAMMES AND QUALIFICATIONS CLASSIFIED AT ISCED LEVEL 0}

(§103) Programmes classified at ISCED level 0 may be referred to in many ways, for example: early childhood education and development, play school, reception, pre-primary, pre-school or educación inicial. For programmes provided in crèches, daycare centres, nurseries or guarderías, it is important to ensure that they meet the ISCED level 0 classification criteria specified. For international comparability purposes, the term 'early childhood education' is used to label ISCED level 0.

\section{Examples Group 1:}

Early childhood educational development programmes [ISCED-P: 010]

Bahrain - دور الحضانة (Nurseries). This early childhood education programme is designed for children under the age of 3 years. It is supervised by the Ministry of Social Development and is considered part of the national pre-school education system. The educational component of the programme aims to develop children's skills and communication and to contribute to their emotional growth according to their needs at different ages. After the age of 3, children may join the three-year Kindergarten programme (ISCED 020), which is supervised by the Ministry of Education. (ISCED-P: 010)

Brazil - Educação Infantil - crèche (Nursery schools/daycare centres). Educação Infantil is the level of education offered in nursery schools (crèche) for children from 0 to 3 years of age. It is the first part of early childhood education (the second part being pre-school for children aged 4 to 5 years old). According to the National Education Law No. $9394 / 1996$ (the main legal instrument that guides education in Brazil), early childhood education is the first stage of basic education and aims at the physical, psychological, intellectual and social development of children complementing the role of the family and the community. The teaching in nursery schools is performed by qualified teachers and follows a formal curriculum. Assessment consists of monitoring and recording the development of children without the intention of mandatorily giving access to a higher education programme. (ISCED-P: 010)

Ghana - Early Childhood Development. This programme is designed for children between the age of 6 months and 3 years. It is supervised by the Department of Social Welfare and delivered by private institutions. After the age of 3 , children may join a two-year Kindergarten programme, which is supervised by the Ministry of Education. (ISCED-P: 010)

Greece - Vrefonipiakos stathmos (Kindergarten/Early childhood education). These early childhood education programmes are organised by municipal or private kindergartens for young children from age 0 to 2 years old. Young children may participate in the programme for one, two or three years. The Vrefonipiakos stathmos meets the educational criteria for classification as early childhood educational development within ISCED 2011. (ISCED-P: 010)

\section{Examples Group 2: \\ Pre-primary education [ISCED-P: 020]}

Cook Islands - Early Childhood Education. Pre-primary education is available to children aged 3 to 5 years. It is delivered in Early Childhood Education Centres, which are usually attached to primary schools. (ISCED-P: 020)

Greece - Nipiagogio (Pre-primary education). Nipiagogio falls under the auspices of the Ministry of Education. It is part of formal education in Greece and aims to familiarise children with the educational process and prepare them for primary school (Dimotiko Scholeio, ISCED 1). It does not contain a non-educational component. Attendance in Nipiagogio has been compulsory since 2007 for children aged 5 years. Four-year-old children can also attend public Nipiagogio as long as there are available places. (ISCED-P: 020)

Jordan - مرحلة الروضة (Kindergarten). This is a pre-school education programme offered to children who are aged at least 3 years and 8 months. The programme, which lasts until the beginning of primary education (at age 6 years), is not part of the compulsory education system. (ISCED-P: 020)

Mali - Éducation préscolaire (Pre-school education). This is a four-year pre-school education programme which is offered to children from the age of 3 years. The aim of this non-compulsory programme is to prepare children for primary education, which starts at the age of 7 years. (ISCED-P: 020) 
Slovak Republic ${ }^{2}$-Materská škola (Kindergarten). Kindergartens are intended for 3- to 6-year-old children. Exceptionally, if there are suitable conditions (mainly if the capacity permits) it is possible to admit 2-year-old children into kindergarten. Kindergarten supports the development of personality in the areas of social, intellectual, body, moral, aesthetic abilities and skills and prepares children to enter Základná škola - 1. stupeň (basic school - 1st stage, ISCED 1). Kindergarten also prepares for life in society based on the individual personalities of children. (ISCED-P: 020)

Turkey - Ana Okullari (Kindergartens). Kindergartens comprise the education of children aged 3 to 5 years. Pre-primary education institutions may be established as independent kindergartens or as nursery classes within other education institutions. In accordance with the Law on Pre-Primary Education Institutions, pre-primary education aims to ensure that children develop physically, mentally and emotionally, and acquire good habits and behaviours; that they are prepared for primary education; that a common environment for their up-bringing is provided for children from disadvantaged backgrounds; and that they learn to speak Turkish properly and correctly. These programmes meet all the criteria for pre-primary education as defined in ISCED-2011. (ISCED-P: 020)

Portugal - Jardins de infância (Kindergartens). Kindergarten education is for children aged 3 to 5 years and is under the tutelage of the Ministry of Education and Science and/or the Ministry of Solidarity and Social Security. Kindergarten education aims to stimulate the cognitive development of the child in a safe environment; to check for special educational needs; and to encourage families to participate in the education process. However, kindergarten education is also designed to prepare children for entry into primary education, to promote citizenship education for a plural society, to stimulate intellectual curiosity and the child's expression and communication with the world. The education component accounts for 25 hours per week and there is a qualified teacher per classroom and one teacher aide per two classrooms. (ISCED-P: 020)

Poland - Wychowanie przedszkolne (Pre-school education). The minimum learning time for typical pre-school classes is 5 hours a day. This time is considered to be the implementation of an education programme (core curriculum) provided by this type of establishment. Wychowanie przedszkolne is designed for children from the age of 3 years to the start of compulsory primary education. This programme meets the ISCED 2011 definition and classification criteria of preprimary education. It is designed to meet the educational and developmental needs of children, typically caters for children aged at least 3 years, and has staff who are adequately trained in pedagogy. (ISCED-P: 020)

\section{Examples Group 3: \\ Integrated programmes [ISCED-P: 010, 020]}

Germany - Kindergarten, Kindertagesstätte (Kindergarten). Early childhood education includes all institutions run by either the non-public or public child and youth welfare services, which cater to children until they start school. In addition to separate institutions for children aged under 3 years and for those aged 3 to 6 years, there are age-integrated institutions for children from 0 to 6 years old. Early childhood curricula of the Länder provide for continuous learning goals and experiences goes up to age 6. In ISCED 2011, programmes in age-integrated institutions are allocated to the categories ISCED-P 010 and 020 according to the age of the children enrolled. (ISCED-P: 010 and 020)

Slovenia - Pedšolska vzgoja (Pre-school education). Slovenia has an integrated system of early learning and care for children aged 1 to 6 years. The unitary system of provision for all children falls under the Ministry of Education, Science, Culture and Sport. Pre-school education groups children from 1 to 3 years (1.starostno obdobje, first age period) (ISCED-P 010), and from 3 to 6 years (2.starostno obdobje, second age period) (ISCED-P- 020). Both programmes satisfy the criteria to be classified at ISCED level 0 . The teaching is performed by qualified teachers and follows a formal curriculum. The educational component accounts for more than 2 hours per day and the school year has more than 100 days of educational activities: $97 \%$ of children attending kindergartens are enrolled in full-time programmes and approximately 3\% of children attend half-day programmes. (Pedšolska vzgoja: ISCED-P: 010 and 020)

The Nordic countries have age-integrated early childhood education programmes. In ISCED 2011 these programmes are allocated to the categories ISCED-P 010 and 020 according to the age of the children.

Denmark - Aldersintegrerede institutioner (Age-integrated centre). Aldersintegrerede institutioner is one of the settings offered within the Dagtilbud (Daycare) programme, which is designed for young children from birth up to the age when they start compulsory primary education (folkeskole, ISCED level 1). This programme meets all the criteria for classification as early childhood education within ISCED. Within ISCED 2011, the Aldersintegrerede institutioner ageintegrated programme is split artificially into the categories of early childhood educational development (ISCED-P 010) for ages 0 to 2 years and pre-primary education (ISCED-P 020) for ages 3 to 5 years. (ISCED-P: 010 and 020) 
Finland - Päiväkoti (Kindergarten) The Päiväkoti programme is designed for children from age 0 to 5 years. Following Päiväkoti, there is a one-year programme called 6-v. lasten esiopetus (pre-primary education for 6-year-olds) which is offered in kindergartens and comprehensive schools and is designed to prepare children for Peruskoulu (comprehensive school, ISCED level 1). All children have the right to attend this pre-primary year (6-v. lasten esiopetus), but education is only compulsory starting with comprehensive school. Within ISCED 2011, the päiväkoti age-integrated programme is split artificially into categories for ages 0 to 2 years and for ages 3 to 5 years. The category 0-2-v. lapset päiväkodeissa (0- to 2 -year-old children in kindergarten) is classified as early childhood educational development (ISCED-P 010). Together, the category 3-5-v. lapset päiväkodeissa (3- to 5-year-old-children in kindergarten) and 6-v. lasten esiopetus (pre-primary for 6-year-olds) comprise the pre-primary years in Finland, and both programmes are classified as ISCED-P 020. (ISCED-P: 010 and 020)

Iceland - Leikskóli (Pre-primary schools) The Leikskóli programme is designed for children from age 0 to 5 years old. Following Leikskóli, primary school education (Grunnskóli l, first section of compulsory education) is offered for children starting from age 6. Within ISCED 2011, the Leikskóli age-integrated programme is split artificially into Leikskóli / for ages 0 to 2 years and Leikskóli // for ages 3 to 5 years. Leikskóli I is classified as early childhood educational development (ISCED-P 010) and Leikskóli II is classified as pre-primary education (ISCED-P 020). (ISCED-P: 010 and 020)

Norway - Barnehage, 0-5 åringer (Kindergarten, ages 0 to 5) Barnehage (kindergarten) is a programme designed for children from age 0 to 5 years old. The programme is not compulsory, and the usual starting age is 1 year. The qualification requirement for teachers is a Bachelorgrad (Bachelor's degree, ISCED level 6), and the programme follows a mandatory national curriculum. Following Barnehage, children begin primary education (Barnetrinnet, ISCED level 1), which is compulsory. Within ISCED 2011, the Barnehage age-integrated programme is split artificially into Barnehage 1 for ages 0 to 2 years and Barnehage 2 for ages 3 to 5 years. Barnehage 1 is classified as early childhood educational development (ISCED-P 010) and Barnehage 2 is classified as pre-primary education (ISCED-P 020). (ISCED-P: 010 and 020)

Sweden - Förskola (Pre-school) The Förskola programme is designed for children up to the age of 5. This education programme also contains a childcare component. Following Förskola, there is a one-year voluntary programme called Förskoleklass (pre-school class) which is designed for 6-year-olds. It takes place in a school-type environment, after which students enter Grundskolan (compulsory school, ISCED level 1) starting from age 7. Within ISCED 2011, the Förskola age-integrated programme is split artificially into Förskola för barn under 3 år (for children younger than 3 years old) and Förskola för barn 3 år eller äldre (for children aged 3 to 5 years). Förskola för barn under 3 år is classified as early childhood educational development (ISCED-P 010). Together, Förskola för barn 3 år eller äldre (ISCED-P 020) and Förskoleklass (ISCED-P: 020) comprise the pre-primary years in Sweden. (ISCED-P: 010 and 020)

\section{Examples Group 4: \\ Programmes delivered from home-based settings to include in ISCED-2011 [ISCED-P: 010, 020]}

Denmark - Kommunal dagpleje (Local authority child-minding). According to the Daycare Facilities Act (Dagtilbudsloven), all children from 26 weeks old must be given the opportunity to attend a daycare facility (Dagtilbud). This therefore obliges the local council of the individual municipality to ensure the necessary number of places for children in the municipality, referred to as guaranteed daycare availability (Pasningsgaranti). Local authority child-minding (Kommunal dagpleje) is a system where child-minders take care of children in private homes. The local authority assigns children to the individual child-minders. The child-minders must follow the same curriculum and have the same educational content obligations as the local authority daycare centres (Kommunale daginstitutioner). One child-minder may take care of up to five children. If two or more persons are carrying out child-minding together, the local authority may allow the child-minders to receive up to ten children. The local authority child-minding programmes meet the main criteria in ISCED 2011 for classification at ISCED level 0: educational properties, institutional context, target age groups, and intensity and duration. For data reporting purposes, data for children below 3 years of age are reported as ISCED-P 010; data for children aged 3 to the starting age for ISCED 1 are reported as ISCED-P 020. (ISCED-P: 010 and 020)

Germany - Kindertagespflege (Child-minding services). For children under the age of 3, early childcare in institutional settings and in a home-based setting are considered as equivalent alternatives by law; both have an explicit educational content; for this reason attendance of a family daycare setting (child-minder) will be reported in ISCED-P: 010. For children between 3 years and compulsory schooling use of a child-minding service is extremely rare and nearly always used to complement institutional care; for reporting in ISCED-P: 020 child-minding therefore is largely insignificant. (Child-minding for children under the age of 3: ISCED-P 010) 


\section{Examples Group 5:}

Programmes delivered from home-based settings to exclude from ISCED 2011 level 0 [No classification]

General example: An example of this would be a private citizen who of his/her own volition provides learning opportunities for young children that nominally meet the ISCED level criteria concerning intentional education, intensity/duration and staff qualification requirements, but are not institutionalised nor regulated by any relevant education authority.

Denmark - Private Pasningsordninger (Private child-minding). Private child-minders may also provide daycare to children from the age of 26 weeks based on an operating agreement with the local authority. The local authority does not refer children to the private child-minders. Although the local authority pays an agreed fee to the child-minder for each child and supervises the scheme, there are no curriculum or educational content obligations. Since there is no substantive educational content, such provision would not be classified as ISCED level 0.

\section{Notes}

1. Paragraph numbers are references to the main ISCED 2011 classification document. See more details in the Reader's Guide.

2. The UNESCO Institute of Statistics (UIS) and the European Union (EU) use "Slovakia" as the official name of "Slovak Republic". 



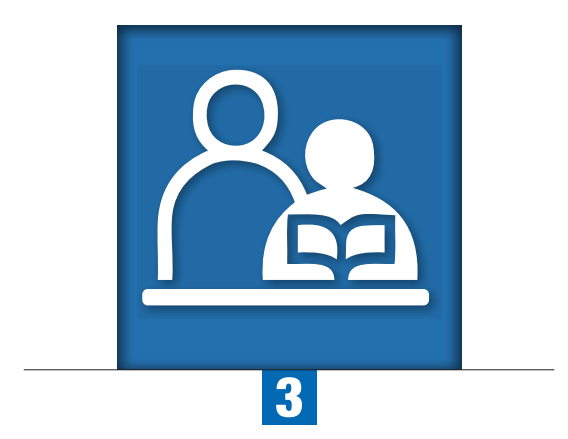

\section{Chapter 3}

\section{ISCED 2011 level 1:}

\section{Primary education}

Primary education usually begins at age 5,6 or 7 , and has a typical duration of six years. Programmes at ISCED level 1 are normally designed to give pupils a sound basic education in reading, writing and mathematics, along with an elementary understanding of other subjects such as history, geography, natural science, social sciences, art and music. The commencement of reading activities alone is not a sufficient criterion for classification of an education programme at ISCED level 1.

Programmes classified at ISCED level 1 may be referred to in many ways, for example: primary education, elementary education or basic education (stage 1 or lower grades if an education system has one programme that spans ISCED levels 1 and 2). For international comparability purposes, the term 'primary education' is used to label ISCED level 1. 


\section{DESCRIPTION}

\section{Definition}

$(\S 120)^{1}$ Programmes at ISCED level 1, or primary education, are typically designed to provide students with fundamental skills in reading, writing and mathematics (i.e. literacy and numeracy) and establish a solid foundation for learning and understanding core areas of knowledge, personal and social development, in preparation for lower secondary education. It focuses on learning at a basic level of complexity with little, if any, specialisation.

(§121) Educational activities at ISCED level 1 (particularly in the early grades) are often organized around units, projects or broad learning areas, often with an integrated approach rather than providing instruction in specific subjects.

\section{Classification criteria (§124)}

\section{Main criteria}

a. Systematic instruction in fundamental knowledge, skills and competencies

(§125) The boundary between ISCED level 0 and level 1 coincide with the transition point in an education system where systematic teaching and learning in reading, writing and mathematics begins.

b. Typical entrance age and duration

(§122) Age is typically the only entry requirement at this level. The customary or legal age of entry is usually not below 5 years old nor above 7 years old. This level typically lasts six years, although its duration can range between four and seven years. Primary education typically lasts until age 10 to 12 .

c. Instruction organised typically by one main class teacher

(§126) Typically, one main teacher is responsible for a group of children and facilitates the learning process. However, a class may have other teachers, especially for certain specialised subjects. Teachers at ISCED level 1 are typically trained in pedagogical approaches for core subjects.

\section{Subsidiary criteria}

a. Part of compulsory education

(§127) The beginning of primary education often coincides with the beginning of compulsory education, except for education systems where some or all of pre-primary education is already compulsory. Therefore, where compulsory education is legislated, it starts with ISCED level 1 or before.

\section{Complementary dimensions}

(§131) None.

All education programmes at ISCED level 1 are coded as ISCED-P 100. There are no categories or sub-categories to be differentiated by the second digit. (§135)

\section{CORRESPONDENCE BETWEEN ISCED 2011 AND ISCED 1997}

(§276) Level 1, primary education, in ISCED 2011 corresponds to level 1 in ISCED 1997. 


\section{GUIDELINES FOR CLASSIFYING PROGRAMMES AND THEIR RELATED RECOGNISED QUALIFICATIONS AT ISCED LEVEL 1}

Primary education usually begins at age 5, 6 or 7, and has a typical duration of six years. Programmes at ISCED level 1 are normally designed to give students a sound basic education in reading, writing and mathematics, along with an elementary understanding of other subjects such as history, geography, natural science, social science, art and music. The commencement of reading activities alone is not a sufficient criterion for classification of an education programme at ISCED level 1. Usually there is one main class teacher at this level, although there may be other teachers for certain specialised subjects. Primary education teachers are usually trained in pedagogical methods for teaching a wide variety of subjects. See Examples Group 1 for examples of typical primary education programmes.

Age is usually the only minimum entry requirement at ISCED level 1. Programmes at the primary level generally require no previous formal education, although it is increasingly common for children to have attended a pre-primary programme before entering primary education. The starting age for primary education often coincides with the starting age of compulsory education, although in some countries compulsory education starts at the pre-primary level.

While the typical duration of primary education is six years, it can last between four and seven years in different countries. Further, the duration of primary education may also vary within countries, in particular in federal countries with more decentralised education systems by regions (see Examples Group 2).

ISCED level 1 includes programmes suited to individuals with special educational needs (disabilities, difficulties or disadvantages) if the content of the instruction is broadly similar to that of other ISCED level 1 programmes (i.e. systematic teaching and learning in the fundamental skills of reading, writing and mathematics), even if the students are not of the typical age for ISCED level 1 (§132) (Examples Group 3).

Some education systems may offer primary-level second chance or re-integration programmes. Such education programmes usually target individuals who:

i) left school before completing primary education, allowing them to re-enter the education system and complete primary education; or

ii) completed primary education but wish to enter an education programme or occupation for which they are not yet qualified. Participants are typically older than the target age group for ISCED level 1 (but not necessarily adults). (§133)

Literacy or basic skills programmes within or outside the school system which are similar in content to programmes in primary education but aimed at those considered too old to enter school are also included at this level because they require no previous formal education. These literacy programmes may be formal or non-formal (§134). See Examples Group 4 for examples of programmes for youngsters or adults outside of the typical age for primary education.

An additional proxy criterion for classification at ISCED level 1 could be entry into the nationally designated primary institutions or programmes. However, in countries where primary education starts at an early age (e.g. age 4 or $4 \frac{1}{2}$ ), children enrolled in these programmes should be classified at ISCED level 1 only if the duration of the school day, the qualifications of the staff, and the level of content of the programme is similar to the grades where children of age 6 are enrolled. Otherwise, any of the earlier grades that correspond more to ISCED level 0 should be classified as pre-primary rather than primary education.

Although the start of compulsory education is a subsidiary criterion for the boundary between ISCED levels 0 and 1 , this criterion is not useful in countries where the start of compulsory schooling is not necessarily related to the beginning of systematic studies. In countries where the age of compulsory attendance (or at least the age at which virtually all students begin their education) comes after the beginning of systematic study for some pupils in the subjects noted above, the first year of compulsory attendance could be used to determine the boundary between ISCED level 0 and ISCED level 1. This latter criterion can be useful when the start of ISCED level 1 reflects the point at which the start of systematic studies in the above subjects starts for all students, not just a select few.

\section{Programmes that span primary education and another ISCED level}

Special consideration is needed for very long programmes (i.e. eight years or more) that span primary education and the levels before or after. In these cases, only those grades, stages or cycles that correspond to the criteria for the respective levels (ISCED levels 0,1 or 2) should be attributed to those levels. (\$128) 
For instructions for cases when the use of the classification criteria does not result in a clear boundary between ISCED levels 0 and 1 , see the ISCED level 0 chapter of the operational manual.

In most countries, ISCED level 1 will correspond to nationally-designated primary education. In countries where 'basic education' covers the entire compulsory school period (e.g. where there is no system break between primary and lower secondary education, and possibly also part of early childhood education), only those grades corresponding to the criteria for ISCED level 1 should be classified as primary education.

If use of the classification criteria does not result in a clear boundary between ISCED levels 1 and 2, the following is recommended: (§130)

i) for programmes spanning ISCED levels 1 and 2 that are organised in stages, the end of the stage closest to six years after the start of ISCED level 1 should be used as the transition point between ISCED levels 1 and 2; and

ii) for programmes spanning ISCED levels 1 and 2 that are not divided into stages, only the first six years should be classified as ISCED level 1, while the remaining years are classified as ISCED level 2.

See Examples Group 5 for programmes that span ISCED levels 1 and 2.

\section{EDUCATIONAL ATTAINMENT AT ISCED LEVEL 1}

When coding educational attainment, special consideration is required for the classification of individuals who attended but did not successfully complete primary education. (\$136). These individuals have the educational attainment code ISCED-A 030 "Some primary education (without level completion)" (Examples Group 6).

Students who have successfully completed ISCED level 1 have the educational attainment code ISCED-A 100.

For educational attainment, recognised qualifications from ISCED level 2 programmes which are not considered sufficient for (full) completion or partial completion of ISCED level 2 (i.e. ISCED-P 241 or 251) are classified at ISCED level 1 (ISCED-A 100). These programmes typically represent a total duration of less than two years at ISCED level 2 or less than eight cumulative years since the start of ISCED level 1 (§137).

\section{EXAMPLES OF PROGRAMMES AND QUALIFICATIONS CLASSIFIED AT ISCED LEVEL 1}

(§123) Programmes classified at ISCED level 1 may be referred to in many ways, for example: primary education, elementary education, basic education (stage 1 or lower grades if an education system has one programme that spans ISCED levels 1 and 2). For international comparability purposes, the term 'primary education' is used to label ISCED level 1.

\section{Examples Group 1: \\ Typical primary education programmes [ISCED-P: 100; ISCED A: 100]}

Austria - Volksschule, 1-4 schulstufe (primary school, Grades 1 to 4). Primary education is compulsory for all children from the age of 6 years. It covers four years and is provided in primary school (Volksschule). Primary education is normally organised into two levels, the first two years (level I) and years 3 and 4 (level II). Upon completion of Grade 4, pupils receive a certificate. Primary education lays the basis for a successful learning experience in secondary education. On the basis of pupils' individual backgrounds, primary school is expected to: strengthen and build social competences, improve language skills, develop and convey elementary knowledge, skills, insights and attitudes leading to the acquisition of the "three Rs" skills (reading, writing, arithmetic). (ISCED-P/ISCED-A: 100)

Belgium (Flemish Community) - Gewoon lager onderwijs (mainstream primary education). Mainstream primary education is aimed at children from age 6 to 12 and typically comprises six years of cumulative study (though can vary from four to eight years). In the first year the systematic learning of reading, writing and mathematics starts. Every group of pupils has its own class teacher who teaches most (or even all) subjects. A separate teacher may be appointed for religious instruction, music and physical education. Mainstream primary education starts in September of the year in which the child turns 6 . For a child who progresses normally, the start of compulsory education coincides with the start of primary education. Upon successful completion of primary education, pupils receive the certificate of primary education. (ISCED-P/ISCED-A: 100) 
France - Enseignement primaire (Primary education). Primary education is five years long and is compulsory from the age of 6 . The programme begins with a cycle of fundamental learning including: one year of preparatory classes (cours préparatoire $-C P$ ) and the first year of elementary classes (cours élémentaire - CE1). The last three years of primary education includes the second year of elementary classes (CE2) and two years of middle-level classes (cours moyen CM1 and CM2). At the end of each cycle there is a national evaluation to assess the level of learning of pupils. However, no certificates are awarded at the end of primary education. Following the successful completion of primary education, pupils enter secondary education. (ISCED-P/ISCED-A: 100)

Greece - Dimotiko Scholeio (Elementary schools). Primary education is compulsory and lasts six years (Grades 1 to 6) starting from the age of 6 . It helps pupils to build up strategies to assimilate knowledge; develop their physical and mental health and cultivate their motor skills; learn the most basic concepts and gradually acquire the ability to derive abstract thoughts from concrete data; acquire the ability to express themselves in oral and written form; become familiar with ethical, religious, national, humanistic values; and cultivate their artistic abilities. Upon completion of Grade 6, pupils receive the primary school-leaving certificate (Titulos spoudon) which gives access to lower secondary school (gymnasium). (ISCED-P/ISCED-A: 100)

India - Primary education. India has a variety of education systems. The most common primary education in the states and territories lasts for five years (Classes I-V) starting from the age of 5 . This free and compulsory programme leads to the primary certificate, which provides access to lower secondary education. (ISCED-P/ISCED-A: 100)

Italy-Scuola primaria (Primary school). Primary education is the first five years of the first cycle of education. Attendance is compulsory for all children aged 6 to 10 years. Primary education comprises three cycles: a first year (Grade 1), which serves to ensure a smooth transition from pre-primary education (scuola dell'infanzia), followed by two two-year cycles (Grades 2 and 3, and Grades 4 and 5). At the end of primary education pupils receive a personal assessment paper, which specifies whether the pupil can be admitted to the first grade of lower secondary education (scuola secondaria di primo grado), together with a certification of the competences acquired by the pupil upon completion of primary school (Certificati e/o Attestati). (ISCED-P/ISCED-A: 100)

Japan-Shogakko (Elementary school). Elementary education is the first stage of compulsory schooling. All children attend elementary school for six years starting from the age of 6 . The goals of elementary education include: understanding and use of Japanese and mathematics, basic understanding of skills required for daily life, scientific observation of nature, appreciation of history, art and music. Following successful completion of elementary school, pupils progress to lower secondary school (Chugakko). (ISCED-P/ISCED-A: 100)

Korea ${ }^{2}$ - Chodeung-hakgyo (Elementary school). Primary education is provided in elementary schools for children aged 6 to 11 years (Grades 1 to 6). The general objective of elementary education is to cultivate healthy, self-reliant, creative and morally sound Korean individuals. This includes developing the ability to express feelings and ideas, solve problems, and appreciate culture and diversity, and the acquisition of the basic skills for life. Upon successful completion of elementary school, pupils receive a certificate (Joleopjang), and may continue to middle school (Jung-hakgyo) (ISCED 2). (ISCED-P/ ISCED-A: 100)

Lebanon - التعليم الابتدائي (Primary education). Primary education covers the first two cycles of compulsory basic education which lasts nine years in total. Each of these two cycles is made up of three grades. The primary education programme normally targets children from age 6 , who are expected to learn the basic skills in reading and mathematics. A foreign language (either English or French) is also introduced at this level. Upon successful completion, pupils may continue to the third cycle of basic education (lower secondary education). (ISCED-P/ISCED-A: 100)

Solomon Islands - Standard Education. Standard education starts at the age of 6 and lasts for six years, from Standard 1 to Standard 6. At the end of Standard 6, students take a formal examination marking the end of primary school. The curriculum includes writing, reading, mathematics, community studies, science, agriculture, art, music, physical education and Christian education. (ISCED-P/ISCED A: 100)

Ukraine - Початкова загальна освіта (Primary education). This is a four-year compulsory education programme for children from age 6 and takes place in elementary schools. Every group of pupils has its own teacher who teaches most subjects. A special teacher may be appointed for music and physical education. Upon successful completion of the programme, pupils receive the certificate of elementary education. (ISCED-P/ISCED-A: 100) 
Canada and the United States - Elementary/primary schools. Primary and secondary education form a continuum, with the duration of elementary or primary school primarily based on institutional characteristics that can differ by province/ state or locality (ranging from three grades to as many as eight). In these countries, the elementary-secondary continuum will be split at the end of Grade 6 for reporting at ISCED level 1, so that the grades contained in each level facilitate crosscountry comparability. This method of reporting programme data will also ensure that, in a national context, comparable programmes are allocated at each level as the level of content is broadly similar at a particular grade across the provinces and states. (ISCED-P/ISCED-A: 100)

Germany - Primarbereich (Primary education). Primary education is the first step of compulsory schooling and covers Grades 1 to 4 in most of Germany, or Grades 1 to 6 in Berlin and Brandenburg. All children attend primary school (Grundschulen) as part of their compulsory schooling between the ages of 6 and 10 (in Berlin and Brandenburg between the ages of 6 and 12). The primary school's role is to lead its pupils from more play-oriented forms of learning at preschool level to the more systematic forms of school learning, providing pupils with the basis for the next educational level (Sekundarbereich l: lower secondary education) and lifelong learning. Lessons at primary school focus on reading, writing, arithmetic, science and a foreign language. Teaching takes place both in lessons concentrating on a specific subject area and in cross-disciplinary classes. The principle of single class teachers covering all or nearly all subjects is used to ensure a consistent pedagogical approach. From Grade 3 onwards children increasingly encounter subject teachers, which helps them prepare for the transition to secondary school, where subject teachers are the rule. For the purpose of international reporting, the duration of ISCED 1 in Germany is reported as four years (i.e. Grades 1 to 4). (ISCED-P/ISCED-A: 100)

Switzerland - Primarschule, école primaire, scuola elementare (Primary school). The entry age to primary education is either 6 years ( 4 cantons), $61 / 2$ years (2 cantons) or 7 years (17 cantons). One canton leaves the decision whether to start school at 6 or 7 years to the communes (local authorities). Since the length of the primary and lower secondary levels combined is a uniform nine years, the differences in the entrance ages translate into different entrance ages all through the school careers of the students. Primary education lasts between four and six years (depending on the canton). Reforms under way will reduce the share of students in four-year programmes. For comparability purposes, the first six years of primary/lower secondary education will be allocated to ISCED level 1. (ISCED-P/ISCED-A: 100)

United Kingdom - Primary school. The starting age of primary school is 5 years in England, Scotland and Wales, and 4 years in Northern Ireland whilst the duration varies between six years (England and Wales) and seven years (Northern Ireland and Scotland). (ISCED-P/ISCED-A 100)

\section{Examples Group 3: \\ Primary education programmes designed for children with special educational needs [ISCED-P: 100; ISCED-A: 100]}

Belgium (Flemish Community) - Buitengewoon lager onderwijs (Special primary education). Special primary education is aimed at children who need special help, temporarily or permanently. This may be due to a physical or mental disability, serious behavioural or emotional problems, or serious learning difficulties. Entry to special primary education is based on the age of the pupil: 6 years old before the 1st of January of the school year. Entry is also possible at the age of 5, which parents may decide based on advice from the class committee and the pupil guidance centre. In special education, a special school statement is drawn up (indicating the type of education for the pupil, based upon the type of disability experienced). Upon completion of the seven-year programme, pupils receive a certificate of primary education (Getuigschrift Basisonderwijs) and may continue to Gewoon secundair onderwijs - 1ste grad (first grade of secondary education, ISCED 2). (ISCED-P/ISCED-A: 100)

Slovak Republic ${ }^{3}$ - Špeciálna základná škola - 1 stupeň (Special basic school - first stage). There are various education programmes for students with special educational needs which are offered in parallel to the regular primary education (Základná škola - 1, stupeň / basic school - first stage, ISCED 1). The special basic school is for children with physical disabilities. There are also variants of basic education programmes for children with learning disabilities and mental handicaps. At age 6, which is the start of ten years of compulsory education, students may enter the four-year full-time 
special basic school programme. Upon successful completion, students receive a Vysvedčenie (certificate) and may continue to the second stage of basic school (ISCED 2). (ISCED-P/ISCED-A: 100)

\section{Examples Group 4: \\ Primary education programmes for individuals outside of the typical age of primary schooling [ISCED-P: 100; ISCED-A: 100]}

Belgium (Flemish Community) - Basiseducatie (Adult basic education). In the Flemish Community of Belgium, adult basic education focuses on improving the general level of literacy, numeracy, Dutch as a second language, the basics of French and English, societal integration and basic ICT skills. Adult basic education is only organised by adult basic education centres. These basic skills courses are allocated at the level of primary education and the first stage of secondary education (ISCED 1 and ISCED 2) according to their content levels. (ISCED-P/ISCED-A: 100).

Egypt - التعليم المجتصعي (Community education). This programme, which is led by the Ministry of Education and supported by local communities and local and international NGOs, targets out-of-school children between the ages of 6 and 14. It provides a second chance to children who have never been enrolled in formal education and those who left school before completing primary education. In community schools, classes are usually limited to 30 students in a multiage group supervised by two facilitators. Pupils are organised according to ability and the pace at which they learn, but within the same classroom. Although the programme is designed as per initial primary education - six years of duration higher-paced students may complete the programme in only three years. After successful completions graduates receive a primary school certificate and may continue to preparatory school. (ISCED-P/ISCED-A: 100).

Hungary - Általános iskola 1-4, évfolyam, felnõttoktatás (Primary-level general school, Grades 1 to 4, part-time education, adult literacy course). Programme for students from age 16, providing literacy skills and similar education to that provided in the four-year full-time general primary-level programme (ISCED 1). Upon successful completion of the programme, students receive a certificate (Bizonyitvány) and may enter the lower secondary level general school (ISCED 2). (ISCED-P/ISCED-A: 100)

Kuwait - التعليم الابتدائي للكبار (Primary education for adults). The primary education for adults programme is designed for youth aged 15 years and older who have either never enrolled in formal education or who dropped out at a younger age. The programme aims at providing a second chance and re-integrating youth into initial education. Unlike the initial primary programme which lasts for five years, the adult programme spans three years only. Upon completion of this formal programme, learners are awarded a primary certificate and they may continue to the intermediate stage for adults (ISCED 2). (ISCED-P/ISCED-A: 100)

South Sudan - Accelerated Learning Programme (ALP) at primary level. This programme is offered within the framework of the Alternative Education System. It is designed to assist early school leavers, children or adults, to accelerate their learning either to (re)join the initial education system or to gain some skills for a productive life. The ALP programme compresses eight years of primary education into four years. The majority of learners are above 10 years of age, while the official entrance age to primary education is 6 years. Upon completion of the programme, learners are awarded a primary education certificate and may progress to secondary education. (ISCED-P/ISCED-A: 100)

Spain - Enseñanzas Iniciales de Educación Básica para personas en edad adulta (Adult education programme at the primary level). These are second chance programmes for people above the ages of compulsory schooling. They are specifically aimed at literacy and to consolidate the basic knowledge of participants. There is no defined theoretical duration, nor restrictions of maximum and minimum duration. The education provided is similar to that of the six-year full-time primary education (Educación primaria, ISCED 1), therefore the theoretical duration is considered equivalent to the ordinary primary education. Upon successful completion of the programme, students may continue to Educación secundaria (lower secondary education). (ISCED-P/ISCED-A: 100)

Sweden - Svenska för vuxna invandrare (Swedish for adult immigrants). This one-year programme teaches the Swedish language and general information about life in Sweden to adult immigrants, aged 16 years or older. It is classified at the level of primary education in the country. Upon completion of the programme, students have the same level of educational attainment as they had before entering. (ISCED-P: 100; ISCED-A: same as before entering) 


\section{Examples Group 5: \\ Programmes that span ISCED levels 1 and 2}

Czech Republic - Základni škola (Basic school). Basic schools provide nine years of basic, compulsory education, usually beginning when the child is 6 years old. It is divided into two stages. The first stage of basic school covers Grades 1 to 5 (primary education, ISCED 1) and the second stage, Grades 6 to 9 (lower secondary, ISCED 2). In Grades 1 to 5 (the first stage of basic school), the teaching and learning process aims to facilitate pupils' transition from pre-school education (ISCED 0) and family care to compulsory, regular and systematic education. With its activity-based and practical nature, the educational process motivates pupils to further learning, guides them to active learning and teaches skills for problem solving. The first stage of the basic education programme is designed to teach a foundational knowledge of general, polytechnical, physical and aesthetic education. (Grades 1 to 5: ISCED-P/ISCED-A: 100; Grades 6 to 9: ISCED-P/ISCED-A: 244)

Denmark - Grundskole (Comprehensive school). Grundskole consists of ten grades. It is compulsory to follow ten years of education at the grundskole level. It is however not obligatory to follow the education in formal school settings. The grundskole consists of a pre-school class (bornehaveklasse) for 6-year-olds followed by nine grades of basic school. In ISCED 2011, the preschool class and Grades 1 to 6 of basic school (grundskole, 1-6 klasse) are classified as primary education (ISCED level 1) and Grades 7 to 9 of basic school (grundskole, 7-9 klasse) are considered as lower secondary education (ISCED level 2). The ten years of comprehensive school are organised around three subject clusters (humanities, practical/creative, and science subjects), supplemented by elective subjects in the last three years (ISCED 2), in which there is some choice of additional subjects that pupils can learn. (Preschool to Grade 6: ISCED-P/ ISCED-A: 100; Grades 7 to 9: ISCED-P/ISCED-A: 244)

Estonia - Põhidaridus, põhikooli (Basic education). Basic education is compulsory for all children from age 7 and lasts nine years (Grades 1 to 9). Basic education is organised into three stages each lasting three years: Grades 1 to 3 , Grades 4 to 6 and Grades 7 to 9 . Students in Grades 7 to 9 also have the opportunity to obtain pre-vocational training in basic schools. In ISCED 2011, the first two stages of basic education (Grades 1 to 6) are classified as primary education (ISCED 1) and the third stage as lower secondary education (ISCED 2). According to the national curriculum, the school must assist in raising young people to be creative, harmonious individuals, who can operate well in different areas of life such as family and society. (Grades 1 to 6: ISCED-P/ISCED-A: 100; Grades 7 to 9: ISCED-P/ISCED-A: 244)

Fiji - Primary School. Primary school starts at age 6 and covers eight grades (Years 1 to 8). The programme is not nationally divided into stages. For international reporting purposes, the programme is considered as spanning ISCED levels 1 and 2. The first six grades are classified as ISCED 1 while the remaining two grades are classified as ISCED 2. (Grades 1 to 6: ISCED-P/ISCED-A: 100; Grades 7 to 8: ISCED-P/ISCED-A: 244)

Finland - Peruskoulu (Comprehensive school). Comprehensive school provides nine years of compulsory general, basic education (primary and lower secondary) starting from the age of 7 . The comprehensive school is divided into two stages: lower stage (Grades1 to 6) and upper stage (Grades 7 to 9). During the first six years, instruction is usually given by a single class teacher. According to the Basic Education Act, the general objective of basic education is to support pupils' growth towards humane and ethically responsible membership of society and to provide them with the knowledge and skills needed in life. Pupils who complete the nine-year comprehensive school receive the basic education certificate. Within ISCED 2011, the lower stage (Grades 1 to 6) is classified as primary education (ISCED 1) and the upper stage as lower secondary (ISCED 2). (Grades 1 to 6: ISCED-P/ISCED-A: 100; Grades 7 to 9: ISCED-P/ISCED-A: 244)

Iceland - Grunnskolar (Compulsory school). Compulsory school covers ten years (Grades 1 to 10) in Iceland. There is no division between primary and lower secondary education at the national level; they form part of the same school level and normally take place in the same school. Generally Grades 1 to 7 are considered the primary grades (ISCED 1) and Grades 8 to 10 the lower secondary grades (ISCED 2). Upon completion of compulsory school pupils receive a certificate. (Grades 1 to 7: ISCED-P/ISCED-A 100; Grades 8 to 10: ISCED-P/ISCED-A: 244)

Kenya - Primary education. National primary education targets children from the age of 6 . It consists of eight grades grouped into two stages: the first stage covers Grades 1 to 3 and the second stage includes Grades 4 to 8 . Grades 1 to 6 are classified as primary education (ISCED 1) and Grades 7 to 8 are considered as lower secondary education (ISCED 2). (Grades 1 to 6: ISCED-P/ISCED-A: 100; Grades 7 to 8: ISCED-P: 244/ISCED-A: 244) 
Malawi - Primary education. The duration of primary education is eight years. The official entry age is 6 years old. In ISCED 2011, Grades 1 to 6 are classified as primary education (ISCED 1) and Grades 7 and 8 as the first two grades of lower secondary education (ISCED 2). These two grades together with the first years of secondary education make up lower secondary education. (Grades 1 to 6: ISCED-P/ISCED-A: 100; Grades 7 to 8: ISCED-P/ISCED-A: 242)

Oman - التعليم الأ ساسي (Basic education). The basic education programme spans ten years of education starting from the age of 6 years. It is organised into two cycles: the first cycle covers Grades 1 to 4 and the second cycle covers Grades 5 to 10. These two cycles are followed by two years of post-basic education (secondary education). In ISCED 2011, the first six grades are classified at ISCED 1 and the remaining four grades at ISCED 2. (Grades 1 to 6: ISCED-P/ISCED-A: 100; Grades 7 to 10: ISCED-P/ISCED-A: 244)

Syrian Arab Republic - التعليم الأساسي (Basic education). The basic education programme lasts nine years (Grades 1 to 9) starting at the age of 6 . It is organised into two stages: stage 1 covers the first four grades (1 to 4 ) and the second stage covers Grades 5 to 9. Upon successful completion, students receive the basic education certificate and may continue to upper secondary education. In ISCED 2011, the first stage is classified as ISCED 1 and the second stage forms ISCED 2. (Grades 1 to 4: ISCED-P/ISCED-A: 100. Grades 5 to 9: ISCED-P / ISCED-A 244)

Timor-Leste - Ensino basico Filial (Basic education). Basic education covers the first nine years of schooling. It consists of three cycles. The first cycle covers the first four grades, the second cycle includes Grades 5 and 6, and the third cycle covers the last three grades. For cross-country comparability, the first two cycles (Grades 1 to 6) are classified as primary education and the last cycle (Grades 7 to 9) is considered as lower secondary general education. (Grades 1 to 6: ISCED-P/ISCED-A: 100; Grades 7 to 9: ISCED-P/ISCED-A: 244)

\section{Examples Group 6:}

Programmes at ISCED level 1 insufficient for level completion, therefore with educational attainment of some primary education (without level completion) [ISCED-P: 100; ISCED-A: 030]

Ethiopia -Alternative Basic Education programme (ABE). The programme is designed to be an accelerated mode for the achievement of universal primary education. The ABE has the same entrance age as regular primary education (6 years old), but it offers a curriculum that compresses the first four grades into three. Upon successful completion of the third grade, students proceed to Grade 5 of regular primary education. (ISCED-P: 100/ISCED-A: 030)

\section{Notes}

1. Paragraph numbers are references to the main ISCED 2011 classification document. See more details in the Reader's Guide.

2. The UNESCO Institute of Statistics (UIS) and the European Union (EU) use "Republic of Korea" as the official name of "Korea".

3. The UNESCO Institute of Statistics (UIS) and the European Union (EU) use "Slovakia" as the official name of "Slovak Republic". 



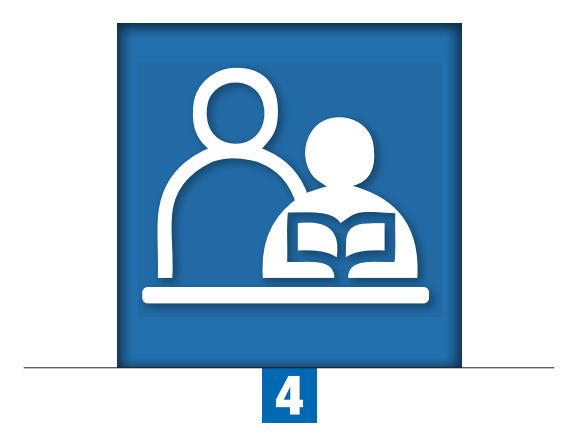

\section{Chapter 4}

\section{ISCED 2011 level 2:}

\section{Lower secondary education}

Programmes at the lower secondary education level are designed to lay the foundation across a wide range of subjects and to prepare children and young people for more specialised study at upper secondary and higher levels of education. The beginning - or the end - of lower secondary education often involves a change of school for young students and also a change in the style of instruction.

Programmes classified at ISCED level 2 may be referred to in many ways, for example: secondary school (stage one/lower grades), junior secondary school, middle school or junior high school. If a programme spans ISCED levels 1 and 2, the terms elementary education or basic school (second stage/upper grades) are often used. For international comparability purposes, the term 'lower secondary education' is used to label ISCED level 2. 


\section{DESCRIPTION}

\section{Definition}

$(\$ 139)^{1}$ Programmes at ISCED level 2 - lower secondary education - are typically designed to build on the learning outcomes from ISCED level 1. Usually the aim is to lay the foundation for lifelong learning and human development upon which education systems may then expand further educational opportunities. Some education systems may offer vocational education programmes at ISCED level 2 to provide individuals with skills relevant to employment.

(§140) Programmes at this level are usually organized around a more subject-oriented curriculum, introducing theoretical concepts across a broad range of subjects. Teachers typically have pedagogical training in specific subjects and, more often than at ISCED level 1, a class of students may have several teachers with specialised knowledge of the subjects they teach.

\section{Classification criteria (§143)}

\section{Main criteria}

a) Programme transition point to a more subject-oriented instruction

(§144) The boundary between ISCED level 1 and ISCED level 2 coincides with the transition point in the education system at which subject-oriented instruction is [first] emphasised.

b) Entry requirements

(§145) This level requires the completion of ISCED level 1 or the ability to study ISCED level 2 content through a combination of prior education as well as life and work experiences. The successful completion of ISCED level 1 or a specific level of achievement may be required for entering some or all ISCED level 2 programmes.

c) Cumulative duration since the beginning of ISCED level 1

(§146) ISCED level 2 ends after 8-11 years of education after the beginning of ISCED level 1.

\section{Subsidiary criteria}

a) Typical entry age

(§141) ISCED level 2 begins after four to seven years of ISCED level 1 education. Students enter ISCED level 2 typically between ages 10 and 13 .

b) Teacher qualifications and organisation of instruction by subject teachers

(§147) The required teacher qualifications may be different at ISCED level 2 compared to ISCED level 1. Teachers at ISCED level 2 are often qualified in one or more specific subjects, as well as in pedagogy. In addition, the organization of instruction can differ from ISCED level 1 as there are more often several teachers for one class, who teach their respective field or fields of specialisation.

c) Relationship with compulsory education

(§148) In many education systems with compulsory education legislation, the end of lower secondary education coincides with the end of compulsory (general) education. 


\section{Complementary dimensions}

(§152) Two dimensions differentiate programmes at ISCED level 2.

(§153) Programme orientation:

- General; and

- Vocational.

(§154) Level completion:

- No completion of ISCED level 2: short, terminal programmes (or sequence of programmes) with a duration of less than 2 years at ISCED level 2 or which end after less than 8 years of cumulative duration since the beginning of ISCED level 1.

- Partial completion of ISCED level 2: programmes representing at least 2 years at ISCED level 2 and a cumulative duration of at least 8 years since the beginning of ISCED level 1, and which are part of a sequence of programmes at ISCED level 3 but are not the last programme in the sequence.

- Completion of ISCED level 2 without direct access to higher ISCED levels: programmes with a duration of at least 2 years at ISCED level 2 and that end after at least 8 years cumulative duration since the beginning of ISCED level 1 but which do not give direct access to ISCED level 3.

- Completion of ISCED level 2 with direct access to higher ISCED levels: any programmes that give direct access to ISCED level 3 regardless of their duration at the level or their cumulative duration since the start of ISCED level 1.

\section{CORRESPONDENCE BETWEEN ISCED 2011 AND ISCED 1997}

The coverage of ISCED level 2 is identical in the 1997 and 2011 revisions of ISCED.

The complementary dimensions for ISCED level 2 are different in the latest version of ISCED. (§278)

a) Programme orientation

ISCED 1997 defines three types of orientation: general, pre-vocational and vocational. In ISCED 2011 there are only two orientations at ISCED level 2: general and vocational. Programmes previously classified as pre-vocational (in ISCED 1997) do not provide labour market-relevant qualifications and are now mainly classified as general education.

b) Level completion and programme destination

ISCED 1997 classifies programmes according to the programmes and levels to which they were designed to lead (the programme destination). At ISCED level 2, three destinations were defined:

$A=$ programmes giving access to upper secondary education at ISCED 1997 level 3A or 3B (i.e. programmes on a direct pathway to tertiary education);

B = programmes giving access to upper secondary education at ISCED 1997 level 3C but not to 3A or 3B (i.e. programmes on a pathway to post-secondary non-tertiary education only or to the labour market); and

$\mathrm{C}=$ programmes without direct access to upper secondary education (i.e. terminal programmes leading to the labour market).

ISCED 2011 classifies programmes according to the type of completion of the level and access to other programmes and levels. ISCED 1997 destinations A and B are combined into a single category in ISCED 2011: (full) completion of ISCED 2011 level 2 with direct access to upper secondary education. ISCED 1997 destination C is sub-divided into three categories in ISCED 2011:

- (full) completion of ISCED 2011 level 2 with no direct access to upper secondary education;

- partial completion of ISCED 2011 level 2 with no direct access to upper secondary education; and

- insufficient for level completion or partial level completion of ISCED 2011 level 2. 


\section{GUIDELINES FOR CLASSIFYING PROGRAMMES AND QUALIFICATIONS AT ISCED LEVEL 2}

Programmes at lower secondary education are designed to lay the foundation across a wide range of subjects and to prepare children and young people for more specialised study at upper secondary and higher levels of education. The beginning - or the end - of lower secondary education often involves a change of school for young students and also a change in the style of instruction. Lower secondary programmes build on primary education and usually include lessons which are more subject-oriented than at the primary level. Typically all students follow the same curriculum and have few or no choices of the subjects to study. By the end of lower secondary education, young people are expected to have a solid foundation in the basic subjects (usually including reading and writing, mathematics, history, geography, science and often a second or foreign language; art, music and physical education may also be part of the curriculum).

In some education systems, programmes may be differentiated by orientation although this is more common at the upper secondary level.

Vocational programmes, where they exist at this level, generally offer options for young people wishing to prepare for direct entry to the labour market in low-or semi-skilled jobs (Examples Group 1). They may also be the first step of vocational education, giving access to more advanced vocational programmes at the upper secondary level (Examples Group 2).

However, in most education systems, the vast majority of students are enrolled in general programmes at the lower secondary level designed to lead to upper secondary education (Examples Group 3).

ISCED level 2 also includes adult education programmes which are similar in content to the education provided at this level (e.g. programmes which allow adults to acquire the basic skills necessary for further learning) and education programmes for individuals with special educational needs (e.g. disabilities, difficulties or disadvantages) (Examples Group 4).

Second chance or re-integration programmes which either review material already covered in lower secondary programmes or provide options for young people who might otherwise leave school with no qualifications also exist (Examples Group 5). They may also provide opportunities for young people to change streams or enter an occupation requiring a lower secondary-level qualification for which their existing studies did not qualify them. These programmes are classified at ISCED level 2 (\$156).

Programmes also exist at this level aimed at the integration of migrants - both adult and youth (Examples Group 6).

In the past, the end of this level often coincided with the end of compulsory education, although today countries are increasingly extending compulsory education into the upper secondary level. Lower secondary programmes last between two and five years, with three years being the most common. Programmes at this level may be shorter than this in some countries where a sequence of programmes within the level may exist. Sequential programmes are less common at the lower secondary level than at upper secondary, but they may exist where a transfer between schools occurs during the level - for example where basic schools cover eight or more grades extending beyond the primary level.

\section{Programmes that span lower secondary education and another ISCED level}

Special consideration is needed for programmes that span lower secondary education and the levels before or after. In these cases, only those grades, stages or cycles that correspond to the criteria for the respective levels (ISCED levels 1 , 2 or 3) should be attributed to those levels. (\$149)

\section{EDUCATIONAL ATTAINMENT AT ISCED LEVEL 2}

As with primary education, programmes at the lower secondary level do not always lead to a final recognised qualification - especially where lower and upper secondary education are offered in the same institution or where the end of lower secondary education does not coincide with the end of compulsory education. Where this is the case, other forms of formal recognition of successful completion of the programme or level may be used to determine the level of educational attainment. This may include formal confirmation of attendance during the full final year of the programme or the right to access higher programmes or levels. 
For the purposes of measuring educational attainment, ISCED 2011 distinguishes between full and partial completion of lower secondary education, although partial level completion is rare at this level.

Programmes leading to full completion of lower secondary education are further sub-divided within ISCED into those which lead to upper secondary education and those which do not. Both give rise to attainment at the lower secondarylevel. The latter group consists typically of vocational programmes often designed for students older than the theoretical age for lower secondary education.

Partial level completion has a very specific meaning and is not synonymous with either "incomplete studies" or "some study" at the level. A programme leading to partial level completion is one which results in a recognised qualification or other formal confirmation by the relevant national education authorities of the successful completion of the programme. The programme is one of a sequence of programmes within the ISCED level but is not the last programme in the sequence. The programme also has to represent a minimum of eight years of cumulative study since the start of primary education and at least two years of (cumulative) study within lower secondary education (Examples Group 7). Note that partial level completion is also different from the sub-category 'no completion of the level'. The latter refers to programmes that do not meet the duration requirements for partial or full level completion and therefore result in educational attainment at the level below the level of the programme (see Examples Group 8).

Partial level completion at the lower secondary level most often occurs where there is a change of school during the level. As part of the transition process between schools, countries may have formal assessments or examinations of pupils' progress leading to recognised successful completion of the given national programme of education.

(§159) For educational attainment, recognized qualifications from ISCED level 2 programmes which are not considered sufficient for completion or partial completion of ISCED level 2 are classified as ISCED level 1.

(§160) Similarly, recognized qualifications from ISCED level 3 programmes which are insufficient for consideration as completion or partial completion of ISCED level 3 are classified as ISCED level 2.

If the programme does not lead to any recognised qualifications (or if successful completion is not otherwise formally recognised by the relevant national authorities), the concept partial level completion does not apply. In such cases, educational attainment of ISCED level 2 can only be allocated at the end of the whole sequence of programmes when the corresponding qualification or formal confirmation of successful completion is obtained.

Programmes at ISCED level 2 that do not give direct access to ISCED 3 and that represent fewer years of study either since the start of primary education (i.e. less than eight) or within lower secondary education (i.e. less than two) or both are regarded as insufficient for either partial completion or full completion of lower secondary education, and result in educational attainment at the primary level (Examples Group 8).

Users of the classification who wish to disseminate results according to a simplified set of educational attainment categories than are acceptable in ISCED-A may need to decide how to treat partial level completion. Depending on the main purpose of the analyses to be made, two different approaches are possible:

(i) Some users may want to know what percentage of the population of interest has successfully completed each ISCED level of education. To do this they would need to classify partial level completion at the level below the level of study (i.e. at primary level in the case of partial completion of lower secondary education).

(ii) Other users may be interested to measure at least some recognised successful study at a given level - especially where this may represent an important transition point in the education system or first-time graduation within a given ISCED level. They would classify partial level completion at the same ISCED level as the level of study (i.e. at the lower secondary level in the case of partial completion of lower secondary education).

Both approaches are valid. It is for the user/analyst to decide which is the more appropriate for their circumstances. It is recommended that treatment of the partial completion applied in the calculation of indicators on educational attainment is indicated in metadata accompanying such statistics. 


\section{EXAMPLES OF PROGRAMMES AND QUALIFICATIONS CLASSIFIED AT ISCED LEVEL 2}

(§142) Programmes classified at ISCED level 2 may be referred to in many ways: secondary school (stage one/lower grades), junior secondary school, middle school or junior high school. If a programme spans ISCED levels 1 and 2, the terms elementary education or basic school (second stage/upper grades) are often used. For international comparability purposes, the term 'lower secondary education' is used to label ISCED level 2.

\section{Examples Group 1: \\ Vocational programmes designed for young people to prepare for direct entry to the labour market in low- or semi-skilled jobs [ISCED-P: 251 or 253; ISCED-A: 100 or 253]}

Tunisia - شعادة مهارة (Certificate of competency). Access to this programme requires the completion of Grade 7, which is the first grade of lower secondary education. It is a two-year vocational education programme leading to the Certificat de Compétence (certificate of competency), which provides access only to the labour market. (ISCED-P/ISCED-A: 253)

\section{Examples Group 2: \\ Vocational programmes preparing for direct labour market entry but also providing access to upper secondary programmes [ISCED-P: 254; ISCED-A: 254]}

Bulgaria - Profesionalni programi- parva stepen na profesionalna kvalifikatsiya sled 6 ili 7 klas (Vocational programme for a first-level professional qualification after completion of Grade 6 or 7). Pupils enter this programme after completing two years at ISCED level 2. The programme is of two- to three-years' duration and leads to two qualifications: basic education attainment (giving access to ISCED level 3) and a first-level professional qualification. (ISCED-P/ISCED-A: 254)

Lebanon - الكفاءة المهنبة (Vocational aptitude). This two-year vocational programme requires the completion of at least

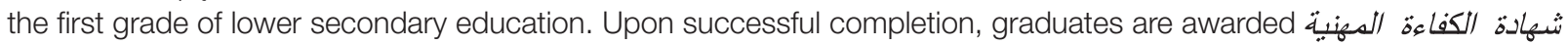
(Certificate of vocational aptitude), which leads to the labour market in addition to higher levels of education. (ISCED-P/ ISCED-A: 254)

Netherlands - WEB-assistentenopleiding (Vocational education: training to assistant level (level 1)). These are full-time or part-time school-based and dual-system education programmes designed for students aged 16 years and older. (Part-time programmes are only open to students aged 18 years and older.) Full-time programmes are typically one year in duration and lead to the MBO niv. 1: assistent (Certificate of secondary vocational education, assistant level). Successful completers may continue studies at the upper secondary level although most enter the labour market. (ISCED-P/ISCED-A: 254)

Examples Group 3:

General programmes giving access to upper secondary education [ISCED-P: 244; ISCED-A: 244]

Australia - Secondary school: 1st stage. The first stage of secondary school lasts three or four years, depending on the length of primary school in the state concerned, and ends with the award of the Year 10 Certificate. Students follow a general school programme, offering the opportunity for further academic progression. (ISCED-P/ISCED-A: 244)

Egypt - التعلبم الإعدادي (Preparatory education). This is a three-year general post-primary programme. Upon completion, graduates are awarded the التعليم الأساسي (Basic education certificate). Students may then proceed to either general or vocational education programmes at the upper secondary level. (ISCED-P/ISCED-A: 244)

Germany - Sekundarbereich I mit Qualifikation für weiterführende Bildungsgänge (Lower secondary schools providing access to general upper secondary programmes). This programme (Grades 5 to 9 or 10) following the four years of primary school is marked by the beginning of a more subject-oriented curriculum. Successful graduates are entitled to enter studies at upper secondary general schools (Gymnasiale Oberstufe) which prepare students to qualify for ISCED 6 or 7 programmes. (ISCED-P/ISCED-A: 244)

India - Upper primary (Grades VI to VIII). Access to this three-year general education programme requires a primary certificate, which is granted on the successful completion of the six-year primary education programme (ISCED 1). Graduates from upper primary education receive the upper primary certificate, which provides access to the high school programme (ISCED 3). (ISCDED-P/ISCED-A: 244). 
Slovenia - Osnovnošolsko izobraževanje (7.-9. razred) (Basic education (Grades 7 to 9)). This is a three-year programme leading to the Zaključno spričevalo (osnovne šole) (Certificate of completion of basic compulsory school) which gives direct access to programmes in upper secondary education. Students enter the programme having successfully completed primary education, typically at the age of 12. (ISCED-P /ISCED-A: 244)

Solomon Islands - Junior Secondary Education (Forms 1-3) This is a three-year general education programme starting after the successful completion of Standard 6 (which marks the end of primary education). At the end of the programme, students take the National Form 3 Examination (NF3) which gives access to upper secondary education. (ISCED-P/ISCED-A: 244)

\section{Examples Group 4:}

Adult education which provides the basic skills necessary for further learning and ISCED level 2 programmes for students with special educational needs [ISCED-P: 243, 244, 253 or 254; ISCED-A: 243, 244, 253 or 254]

Belgium (Flemish Community) - Buitengewoon secundair onderwijs - opleidingsvorm 1 en 2 (Special secondary education - types 1 and 2). This programme is aimed at children who need special help, temporarily or permanently. In special secondary education, education is organised in accordance with the type of disability and the possibilities of the pupil. Education type 1 provides social education aimed at the integration of the pupil in a sheltered environment. Education type 2 provides general and social education and training for work aimed at the pupils' integration in a sheltered living and working environment. (ISCED-P/ISCED-A: 253)

Germany - Sekundarbereich I, Abendschulen (Lower secondary evening schools). This programme (of one to two years of duration) is intended for adults with no or low ISCED level 2 qualifications (e.g. Hauptschulabschluss) who want to obtain a higher qualification at the lower secondary level (mostly Mittlerer Schulabschluss). (ISCED-P/ISCED-A: 244)

Kuwait - المرحلة المتوسطة للكبار (Adult intermediate stage). This formal adult education programme normally targets adults aged 15 years and older who have completed primary education. Similarly to the initial intermediate stage (lower secondary), the programme has a theoretical duration of four years. Upon successful completion, graduates can proceed to upper secondary adult education programmes. (ISCED-P/ISCED-A: 244)

Mexico - Capacitación para el trabajo (Lower secondary job training). The typical duration of these programmes is two years, although there are also longer or shorter programmes. Students in this programme are commonly adults. The programme is oriented to train persons (15 years and older) to introduce them to the world of work. (ISCED-P/ISCED-A: 243).

\section{Examples Group 5:}

Second chance or reintegration programmes for students who have not yet completed lower secondary education [ISCED-P: 243, 244, 253 or 254; ISCED-A: 243, 244, 253 or 254]

Ireland - Youthreach (Foundation Level). This is a two-year general programme designed for those who leave school with no qualifications. Certification is available at a range of levels, including a Junior Certificate at the lower secondarylevel. (ISCED-P/ISCED-A 244)

Morocco - التكوبن المهني : مستوى التخصص (Professional training: specialisation level). Access to this programme is open to students at the level of the sixth grade of primary education who are at least 15 years of age. This two-year programme prepares students to join the labour market. In addition, it provides access to programmes at higher levels of education (ISCED 3). (ISCED-P/ISCED-A: 254)

Slovak Republic ${ }^{2}$ - Praktická škola (Practical school). This is a one- to three-year general programme providing education and training for simple work activities designed to give a second chance to young people who have already attended a full cycle of lower secondary education. Entrants are typically aged 15 years or older. The content is not sufficiently complex to be classified at the upper secondary level. It leads to a Vysvedčenie (Certificate). (ISCED-P/ISCED-A: 243)

\section{Examples Group 6: \\ Programmes designed for the integration of new migrants \\ [ISCED-P: 241, 243, 244, 253 or 254; ISCED-A: 100, 243, 244, 253 or 254]}

Belgium (Flemish Community) - Onthaalklas voor anderstalige nieuwkomers (Reception class for immigrants). Reception education is aimed at students who hardly speak any Dutch and who recently arrived in Belgium. The main goal is to learn Dutch and to integrate participants into the type of secondary education and discipline (field of study) that most closely matches their individual capabilities. The curriculum of the reception year is very much focused on the 
acquisition of Dutch. A person can enter the reception class when he/she meets the following criteria: 1) on 31 December after the start of the school year, being at least 12 years old and not older than 18 years old; 2) being a recent immigrant (maximum one year of residence in Belgium); 3) having a mother tongue or language at home that is not Dutch; 4) having insufficient knowledge of Dutch to follow the lessons in mainstream education; and 5) maximum nine months of being enrolled in a school with Dutch as the main instruction language. (ISCED-P: 241; ISCED-A: 100)

Luxembourg - Classes d'accueil (ACCU) (12-15 ans) and Classes d'insertion pour jeunes adultes (CLIJA) (16-17 ans) (Welcome classes for 12- to 15-year-olds and 16- to 17-year-olds respectively). These are one-year general programmes intended to prepare young people newly arrived from abroad to enter the regular school system either at the lower secondary level (Classes d'accueil (ACCU) (12-15 ans)) or at the upper secondary level (Classes d'insertion pour jeunes adultes (CLIJA) (16-17 ans)). (ISCED-P: 241/ISCED-A: 100 and ISCED-P/ISCED-A: 244 respectively)

Norway - Introduksjonsordning og opplæring I norsk og samfunnskunnskap for nyankomne innvandrere (Introduction programme to Norwegian language and social conditions for new immigrants). This is a programme of up to two years' duration leading to the Fullført introduksjonsprogram (Certificate in Norwegian language and civic studies for adult immigrants). It does not provide access to higher levels of education. (ISCED-P: 241; ISCED-A: 100).

\section{Examples Group 7:}

Programmes and qualifications resulting in partial level completion [ISCED-P: 242 or 252; ISCED-A: 242 or 252]

Lithuania - Profesinio mokymo programa, skirta asmenims, neturintiems pagrindinio išsilavinimo (Vocational education programmes for persons without basic education). After completion of primary education, students may enter this twoyear programme leading to a vocational qualification certificate which allows students to continue education in other lower secondary programmes, giving at the end access to the upper secondary level. (ISCED-P/ISCED-A: 252)

\section{Examples Group 8: \\ Programmes at ISCED level 2 insufficient for level completion, therefore with educational attainment of ISCED level 1 [ISCED-P: 241 or 251; ISCED A: 100]}

Algeria - التكوين المعني المختص (Specialised vocational training). This one-year programme is designed to prepare young adolescents for direct access to the labour market. Access to the programme is available to young people aged at least 11 years who are able to read and write. Upon completing the programme, graduates receive a leaving certificate, which is locally considered higher than primary education but less than lower secondary. The programme is considered insufficient for ISCED 2 completion. (ISCED-P: 251; ISCED-A: 100)

Estonia - Põhihariduse nõudeta kutseõpe (Vocational education for persons who do not have basic education and who have exceeded the age of compulsory school attendance). The entrance age to this programme is around 17 to 19 years and its duration is of half to two and a half years. The entry requirement to this programme is completion of ISCED 1. Graduates obtain a vocational education institution leaving certificate which is considered beyond ISCED level 1 but is insufficient for classification as an ISCED level 2 qualification. (ISCED-P: 251; ISCED-A: 100)

\section{Notes}

1. Paragraph numbers are references to the main ISCED 2011 classification document. See more details in the Reader's Guide.

2. The UNESCO Institute of Statistics (UIS) and the European Union (EU) use "Slovakia" as the official name of "Slovak Republic". 


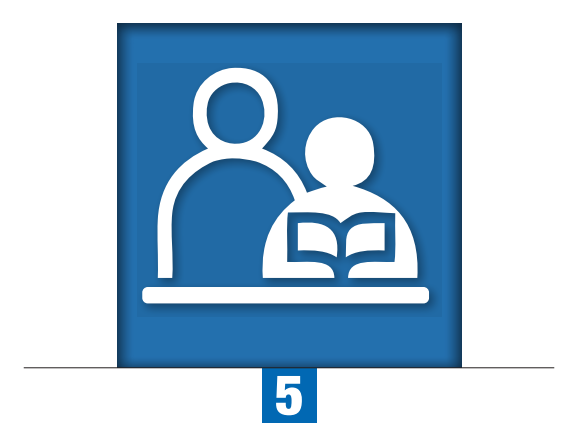

\section{Chapter 5}

\section{ISCED 2011 level 3:}

\section{Upper secondary education}

Programmes at the upper secondary education level are more specialised than those at lower secondary and offer students more choices and diverse pathways for completing their secondary education. The range of subjects studied by a single student tends to be narrower than at lower levels of education, but the content is more complex and the study more in-depth. Programmes offered are differentiated by orientation and often by broad subject groups.

Programmes classified at ISCED level 3 may be referred to in many ways, for example: secondary school (stage two/upper grades), senior secondary school or (senior) high school. For international comparability purposes, the term 'upper secondary education' is used to label ISCED level 3. 
DESCRIPTION

\section{Definition}

$(\S 162)^{1}$ Programmes at ISCED level 3 - upper secondary education - are typically designed to complete secondary education in preparation for tertiary education or provide skills relevant to employment, or both.

(§163) Programmes at this level offer students more varied, specialised and in-depth instruction than programmes at ISCED level 2. They are more differentiated, with an increased range of options and streams available. Teachers are often highly qualified in the subjects they teach, particularly in the higher grades.

\section{Classification criteria (\$166)}

\section{Main criteria}

a. Content

(§167) Programmes which form the second/final stage of secondary education may be either general or vocational programmes. Some of these programmes allow direct access to ISCED level 4, and/or level 5,6 or 7 .

b. Entry requirements

(\$168) ISCED level 3 requires the completion of lower secondary education (ISCED level 2) or the ability to handle ISCED level 3 content through a combination of prior education as well as life and work experiences. A specific ISCED level 2 qualification or a specific level of achievement may be required for entering some or all ISCED level 3 programmes.

c) Cumulative duration since the beginning of ISCED level 1

(\$164) ISCED level 3 begins after 8-11 years of education since the beginning of ISCED level 1. Pupils enter this level typically between ages 14 and 16. ISCED level 3 programmes usually end 12 or 13 years after the beginning of ISCED level 1 (or around age 17 or 18), with 12 years being the most widespread cumulative duration. However, exit from upper secondary education may range across education systems from usually 11 to 13 years of education since the beginning of ISCED level 1.

\section{Subsidiary criteria}

a) Programme transition point

(§169) The transition from ISCED level 2 to ISCED level 3 coincides with the transition point in an education system at which programmes offer students more varied, specialised and in-depth instruction in specific subjects or fields. Typically programmes are more differentiated, and an increased range of options and streams are available.

b) Teacher qualifications

(§170) Standards for teacher qualifications may be different at ISCED level 3 compared to ISCED level 2. In addition to pedagogical training, teachers may be more qualified with respect to the subject matter they teach. 


\section{Complementary dimensions}

(§174) Two dimensions differentiate programmes at ISCED level 3.

(§175) Programme orientation:

- General; and

- Vocational.

(§176) Level completion:

- No completion of ISCED level 3: short, terminal programmes (or sequence of programmes) with a duration of less than 2 years at ISCED level 3 or which end after less than 11 years of cumulative duration since the beginning of ISCED level 1.

- Partial completion of ISCED level 3: programmes representing at least 2 years at ISCED level 3 and a cumulative duration of at least 11 years since the beginning of ISCED level 1, and which are part of a sequence of programmes at ISCED level 3 but are not the last programme in the sequence.

- Completion of ISCED level 3 without direct access to first tertiary programmes at ISCED level 5, 6 or 7: programmes with duration of at least 2 years at ISCED level 3 and that end after at least 11 years cumulative duration since the beginning of ISCED level 1. These programmes may be terminal or give direct access to ISCED level 4 only.

- Completion of ISCED level 3 with direct access to first tertiary programmes at ISCED level 5, 6 or 7: any programmes that give direct access to first tertiary programmes at ISCED level 5, 6 or 7 regardless of their duration at level 3 or their cumulative duration since the start of ISCED level 1.

(§178) This level can include some second-cycle vocational programmes in cases where the transition points at the end of the second cycle correspond to transition points between levels in other, mainly general, pathways offered in the system.

(§179) This level also includes upper secondary-level second chance or re-integration programmes. Such programmes usually target individuals who:

- left school before completing upper secondary education, allowing them to re-enter the education system and complete upper secondary education; or

- completed upper secondary education but wish to enter a programme or occupation for which they are not yet qualified.

\section{CORRESPONDENCE BETWEEN ISCED 2011 AND ISCED 1997}

The coverage of ISCED level 3 is virtually identical in the 1997 and 2011 versions of ISCED, with the following exception included in ISCED 1997 level 4:

(§190) Programmes designed to review the content of ISCED level 3 programmes - for example, with the aim of preparing students for tertiary education entrance examinations - should be included in ISCED [2011] level 3.

The complementary dimensions for ISCED level 3 are different in the latest version of ISCED. (§278)

a) Programme orientation

ISCED 1997 defines three types of orientation: general, pre-vocational and vocational. In ISCED 2011 there are only two orientations at ISCED level 3: general and vocational. Programmes previously classified as pre-vocational (in ISCED 1997) do not provide labour market-relevant qualifications and are now mainly classified as general education. 
b) Level completion and programme destination

ISCED 1997 classified programmes according to the programmes and levels to which they were designed to lead (the programme destination). At ISCED level 3, three destinations were defined:

$A=$ programmes giving access to tertiary education at ISCED 1997 level 5A (i.e. programmes on a direct pathway to doctoral or equivalent programmes);

$B=$ programmes giving access to tertiary education at ISCED 1997 level 5B but not to 5A (i.e. programmes giving access to more professionally-oriented tertiary education); and

$\mathrm{C}=$ programmes without direct access to tertiary education (i.e. terminal programmes or programmes giving access to other programmes at ISCED 1997 levels 3 or 4 only).

ISCED 2011 classifies programmes according to the type of completion of the level and access to other programmes and levels. ISCED 1997 destinations A and B are combined into a single category in ISCED 2011: (full) completion of ISCED 2011 level 3 with direct access to tertiary education. ISCED 1997 destination C is sub-divided into three categories in ISCED 2011:

- (full) completion of ISCED 2011 level 3 with no direct access to tertiary education;

- partial completion of ISCED 2011 level 3 with no direct access to post-secondary education; and

- insufficient for level completion or partial level completion of ISCED 2011 level 3.

\section{GUIDELINES FOR CLASSIFYING PROGRAMMES AND QUALIFICATIONS AT ISCED LEVEL 3}

Programmes at the upper secondary level are more specialised than those at lower secondary and offer students more choices and diverse pathways for completing their secondary education (§163). The range of subjects studied by a single student tends to be narrower than at lower levels of education, but the content is more complex and the study more in-depth.

Programmes offered are differentiated by orientation (\$167) and often by broad subject groups.

General programmes are usually designed for students planning to continue to academic or professional studies at the tertiary level. Students will often begin to specialise in specific fields, such as the sciences, humanities or social sciences, even if they are expected to continue to take some courses in basic subjects like the national language, mathematics and, perhaps, a foreign language. The successful completion of these programmes is nearly always the entry requirement for first degrees at university or equivalent level (Examples Group 1). There can also be general programmes at ISCED level 3 which do not provide access to tertiary education, but these are comparatively rare. An example has, however, been included in Examples Group 10.

In some countries, the entry requirements for ISCED level 6 programmes are different from those for ISCED level 5. Where this is the case, both qualifications should be classified in ISCED level 3.

Vocational programmes exist both to offer options to young people who might otherwise leave school without any qualifications from an upper secondary programme (Examples Group 2) as well as for those wishing to prepare for skilled worker and/or technician-level jobs (Examples Group 3).

Second chance or re-integration programmes which either review material already covered in upper secondary programmes (Examples Group 4) or provide opportunities for young people to change streams or enter an occupation requiring an upper secondary-level attainment or qualification for which their existing studies did not qualify them (Examples Group 5) are classified at ISCED level 3 (§179).

By contrast, programmes following successful completion of upper secondary education which are either designed to broaden the options for progression to the tertiary level or are second-cycle vocational programmes should be classified at ISCED level 4 (§185). Second-cycle vocational programmes which run in parallel to other programmes at the upper secondary level (mostly general programmes) should be normally classified at ISCED level 3 (§179).

Upper secondary education lasts between two and five years, with three years being the most common. Programmes at this level may be shorter than this in some countries where a sequence of programmes within the level may exist, each leading to a different nationally-recognised qualification. Sequential programmes at the upper secondary level may exist where the end of compulsory education occurs within upper secondary education or where there are common 
exit points from education during the level which need to be documented by a recognised qualification (for example, in order to seek employment or further training). Where such a sequence exists, it is most commonly a sequence of general programmes though a vocational sequence is also possible (Examples Group 7).

\section{Programmes that span upper secondary education and another ISCED level}

Special consideration is needed for programmes that span upper secondary education and the levels before or after. In these cases, only those grades, stages or cycles that correspond to the criteria for the respective levels (ISCED levels 2, 3,4 or 5) should be attributed to those levels. (\$171)

(§173) If the theoretical duration of a vocational ISCED level 3 programme is two or more years longer than the theoretical duration of a general ISCED level 3 programme in the same education system, the programme should be regarded as spanning upper secondary education (ISCED level 3) and post-secondary non-tertiary education (ISCED level 4) or short-cycle tertiary education (ISCED level 5). The grades, stages or cycles which extend beyond the general ISCED level 3 programme should be classified as ISCED level 4 or 5 depending on the complexity of their content. (Examples Group 6).

\section{EDUCATIONAL ATTAINMENT AT ISCED LEVEL 3}

For the purposes of measuring educational attainment, ISCED 2011 distinguishes between full and partial completion of upper secondary education.

Partial level completion has a very specific meaning and is not synonymous with either "incomplete studies" or "some study" at the level. A programme leading to "partial level completion" is one which results in a qualification recognised by the relevant national education authorities which is awarded to successful completers of the programme at a specified point within the sequence of programmes but is not equivalent to the qualification conferred by successful completion of the full sequence. The programme is one of a sequence of programmes within the ISCED level but is not the last programme in the sequence. The programme also has to represent a minimum of eleven years of cumulative study since the start of primary education and at least two years of (cumulative) study within upper secondary education (Examples Group 7). Note that partial level completion is also different from the sub-category no completion of the level. The latter refers to programmes that do not meet the duration requirements for partial or full level completion and therefore result in an educational attainment at the level below the level of the programme (see Examples Group 9).

(§182) For educational attainment, recognized qualifications from ISCED level 3 programmes which are not considered as sufficient for ISCED level 3 completion [or partial completion] are classified as ISCED level 2.

(§183) Similarly, recognized qualifications from ISCED level 4 programmes which are insufficient for consideration as ISCED level 4 completion are classified as ISCED level 3.

If the programme does not lead to any recognised qualifications (or if successful completion is not otherwise formally recognised by the relevant national authorities), the concept partial level completion does not apply. In such cases, educational attainment of ISCED level 3 can only be allocated at the end of the whole sequence of programmes when the corresponding qualification is obtained.

Programmes at ISCED level 3 that do not give direct access to a higher ISCED level and that represent fewer years of study either since the start of primary education (i.e. less than eleven) or within upper secondary education (i.e. less than two) or both are regarded as insufficient for either partial completion or full completion of upper secondary education, and result in educational attainment at the lower secondary level (Examples Group 8).

Vocational programmes leading to full completion of upper secondary education are further sub-divided within ISCED into those which lead to tertiary education (Examples Group 9) and those which do not (Examples Group 10). Both give rise to attainment at the upper secondary level. The latter group of programmes may or may not give access to post-secondary non-tertiary education. 
In some cases a programme can lead to several different qualifications. The programme itself should be classified according to the characteristics of the qualification granting the most access to further studies thereafter. The educational attainment of persons who have completed such a programme should be determined with respect to the highest qualification that is awarded to the individual (Examples Group 11).

Users of the classification who wish to disseminate results according to a simplified set of educational attainment categories than are acceptable in ISCED-A (i.e. at 1-digit ISCED level) may need to decide how to treat partial level completion. Depending on the main purpose of the analyses to be made, two different approaches are possible:

i) Some users may want to know what percentage of the population of interest has successfully completed each ISCED level of education (in the case of sequential programmes successful completion of the final programme in the sequence within the ISCED level). To do this they would need to classify partial level completion at the level below the level of study (i.e. at lower secondary level in the case of partial completion of upper secondary education).

ii) Other users may be interested to measure at least some recognised successful study at a given level - especially where this may represent a potential exit point from the education system or "first-time" graduation within a given ISCED level. They would classify partial level completion at the same ISCED level as the level of study (i.e. at the upper secondary level in the case of partial completion of upper secondary education).

Both approaches are valid. It is for the user/analyst to decide which is the more appropriate for their circumstances. It is recommended that treatment of the partial completion applied in the calculation of indicators on educational attainment is indicated in metadata accompanying such statistics.

\section{EXAMPLES OF PROGRAMMES AND QUALIFICATIONS CLASSIFIED AT ISCED LEVEL 3}

(§165) Programmes classified at ISCED level 3 may be referred to in many ways: secondary school (stage two/ upper grades), senior secondary school, or (senior) high school. For international comparability purposes the term "upper secondary education" is used to label ISCED level 3.

\section{Examples Group 1: \\ General programmes giving access to first degree programmes at tertiary level (ISCED 2011 levels 6 or 7 ) [ISCED-P: 344; ISCED-A: 344]}

Egypt - الثانوية العامة (General secondary). This general secondary education programme requires the possession of شعادة التعليم الأساسي العيد (Basic education certificate), which is awarded upon successful completion of basic education (ISCEED 2). The general secondary programme lasts three years, after which the graduates are awarded the general secondary certificate which gives access to higher levels of education including tertiary and non-tertiary education. (ISCED-P/ ISCED-A: 344)

Estonia - Üldkeskharidus (General secondary education). This is a three-year programme leading to the general upper secondary leaving certificate which gives direct access to programmes Bakalaureuseõpe (Bachelor's study programmes). Students enter the programme having successfully completed lower secondary education typically at the age of 16 years. (ISCED-P/ISCED-A: 344)

France - Enseignement de second cycle général du second degré conduisant au baccalauréat général ou technologique ou au brevet de technicien (Secondary general education (second cycle), preparing towards a Bac général, technologique or Brevet de technicien). This is a three-year programme following successful completion of lower secondary education. It is the typical route to tertiary education and nearly all holders of these qualifications continue to such programmes of study. (ISCED-P/ISCED-A: 344)

Germany - Allgemeinbildende Programme im Sekundarbereich II (Upper secondary schools, general). These are threeyear upper secondary general programmes (Gymnasiale Oberstufe), comprising Grades 10 to 12 or 11 to 13, which lead to the Hochschulreife (university entrance qualification). Such programmes in Gymnasium (including Berufliches Gymnasium), Integrierte Gesamtschule or Freie Waldorfschule (grammar, comprehensive or Waldorf schools) are attended by students who have earned the Mittlerer Schulabschluss (lower secondary certificate with access to upper secondary). Successful graduates of these programmes are entitled to enter ISCED level 6 or 7 programmes. (ISCED-P/ISCED-A: 344) 
Saudi Arabia - التعليم الثانوي العام (General secondary education). This is a three-year full-time general education programme that requires the completion of intermediate education (ISCED 2). On completion of the programme, graduates are awarded the national general secondary certificate, which leads to tertiary education. (ISCED-P/ ISCED-A: 344)

Swaziland - Senior Secondary Certificate. This is a two-year upper secondary programme offered to lower secondary graduates which gives direct access to all post-secondary programmes. The official entrance age is 16 years. (ISCED-P/ ISCED-A: 344)

Switzerland - Gymnasiale Maturität, maturité gymnasiale, maturità (Schools leading to the school-leaving certificate). These are 3.5-year general programmes designed for young people who have successfully completed lower secondary education and wish to continue their studies at university level. It prepares them for the university entrance exam. (ISCED-P/ISCED-A: 344)

\section{Examples Group 2: \\ Vocational programmes designed for young people wishing to enter the labour market directly or who might otherwise leave school without any qualifications from an upper secondary programme [ISCED-P: 351 or 353; ISCED-A: 254 or 353]}

Bulgaria - Profesionalni programi - parva stepen na profesionalna kvalifikatsiya sled 8 klas (TVET programmes after completion of the 8th grade leading to a first-level professional qualification). These are two-year vocational programmes after completion of lower secondary education leading to Profesionalni programi- parva stepen na profesionalna kvalifikatsiya (First-level professional qualification). The programmes do not lead to the upper secondary school-leaving certificate - Sredno obrazovanie - which gives direct access to tertiary education. Since the programme represents only ten years of study since the start of primary education, it is insufficient for completion or partial completion of ISCED level 3. (ISCED-P: 351; ISCED-A: 254)

Slovenia - Nižje poklicno izobraževanje (Short-term vocational upper secondary education). This is a two- to three-year vocational programme designed for young people who have successfully completed nine years of basic (compulsory) education or who have completed a modified education programme for children with special educational needs. The programme is also available to those who have attended basic school for nine years but failed to complete it successfully (i.e. they have satisfied the "basic school obligation"). According to the law, these programmes last from two to three years, ending with a final exam. Students' general knowledge acquired in the last years of basic school is reinforced, whilst new general and vocational knowledge and qualifications for simple jobs are gained. (ISCED-P/ISCED-A: 353)

\section{Examples Group 3: \\ Vocational programmes preparing for skilled worker or technician-level jobs [ISCED-P: 353 or 354; ISCED-A: 353 or 354]}

Australia - Certificate III. These are advanced vocational courses for recognised trades, technicians and other skilled professions. There are no formal minimum entry requirements but young people entering the programme are typically aged 15 or 16 years. These programmes typically have a duration of 1 to 2 years at ISCED level 3 or 14 to 15 years since the start of ISCED level 1. Successful completers do not have access to tertiary education but may enter Certificate IV programmes at ISCED 2011 level 4 or enter the labour market. (ISCED-P/ISCED-A: 353)

France - Enseignement de second cycle professionnel des écoles sociales conduisant aux diplômes de moniteurs éducateurs et équivalents (Vocational secondary education (second cycle) in health and care schools preparing for qualifications of Moniteur éducateur (and equivalent)). These are two-year vocational programmes in certain social services (e.g. moniteur éducateur, technicien de l'intervention sociale et familiale - instructor-educator, social and family intervention professional) designed for older students who have successfully completed lower secondary education. The resulting qualifications are equivalent to the baccalauréat and give access to programmes at the tertiary level. (ISCED-P/ ISCED-A: 354)

France - Enseignement de second cycle professionnel du second degré conduisant au Baccalauréat Professionnel ou équivalent (Vocational secondary education (second cycle) preparing for the Bac Professionne). This programme of three years takes place mainly in an educational/training institution but includes training periods in an enterprise and 
prepares participants to enter working life. It is also possible to earn the Bac professionnel by apprenticeship, with instructional time shared between an educational/training institution and an enterprise. The qualification gives direct access to the labour market. A minority of graduates continue to higher studies mainly to earn the Brevet de technicien supérieur (BTS) (Advanced Technician Diploma) at ISCED level 5. (ISCED-P/ISCED-A: 354)

Germany - Berufsschulen (Duales System) Erstausbildung (Vocational Schools (Dual System) Training). This is a 2-, 3- or 3.5-year special form of apprenticeship which comprises education and training both at a vocational school and in an enterprise. In the majority of cases the duration is three years. Students must have completed ISCED level 2. The programme leads to a Lehrabschluss (Qualification of the Dual System). Graduates qualify for Fachoberschulen (one year), Fachschulen or for entry into the labour market. (ISCED-P/ISCED-A: 354)

Lebanon - الثانوية الدهنية (vocational secondary). This programme requires the completion of ISCED 2 (either general or vocational) and it lasts three years on a full-time basis. Normally participants are aged between 15 and 17 years. This vocational secondary programme, which is considered as full completion of ISCED 2011 level 3, does not provide any direct access to a higher ISCED level. (ISCED-P/ISCED-A: 353)

Slovak Republic ${ }^{2}$ - Stredá odborná škola - štúdium s maturity (Specialised secondary school - leading to the maturita). This is a four-year programme providing both general education and vocational training oriented towards execution of more demanding professional activities. Successful completers receive both a general qualification - Vysvedčenie 0 maturitnej skúške (maturita) - and a vocational qualification - Výučný list (apprenticeship certificate) - and may proceed either to tertiary education or to the labour market. (ISCED-P/ISCED-A: 354)

\section{Examples Group 4: \\ Programmes designed to review the content of ISCED level 3 programmes - for example, with the aim of preparing students for tertiary education entrance examinations [ISCED-P: 344 or 354; ISCED-A: 344 or 354]}

Australia - Enabling courses. These are short (less than one year) bridging or supplementary programmes provided by universities to disadvantaged students who need additional preparation prior to commencing a formal award course or for university students to strengthen their backgrounds in a particular field of study. The programmes are designed to reinforce studies already undertaken at the upper secondary level to ensure that participants are fully prepared to begin their studies at the tertiary level. (ISCED-P/ISCED-A: 344)

\section{Examples Group 5:}

Second chance or reintegration programmes for students who have not yet completed upper secondary education [ISCED-P: 343, 344, 353 or 354; ISCED-A: 343, 344, 353 or 354]

Morocco - التكوين الدهني: مستوى تثني (Vocational training: technician level). This two-year vocational programme is offered to students who reached the last grade of upper general secondary education. It gives a second chance to those who wish to change to the vocational track. By the end of the programme, graduates are awarded a دبلوم تقني (technical diploma), which provides direct access only to the labour market. (ISCED-P/ISCED-A: 353)

Netherlands - VAVO-HAVO en VAVO-VWO (Senior general secondary education for adults). These are one- to three-year part-time programmes leading to the hoger algemeen voortgezet onderwijs (HAVO) and voorbereidend wetenschappelijk onderwijs (VWO) qualifications which give direct access to programmes at the tertiary level. They are second chance programmes and are the part-time counterparts of the full-time initial programmes of two years for HAVO and three years for WWO. Entry requirements are completion of lower secondary education. The adult programmes lead to the same qualifications as the initial programmes but with a somewhat older entry age, typically 18 instead of 16 years. (ISCED-P/ ISCED-A: 344)

Slovenia - Poklicni tecaj in poklicna matura (Vocational course leading to vocational Matura). This is a one-year vocational course providing a bridge between general and vocational education. It allows graduates from general, classical and other gymnasiums (or those who have finished the final year of these programmes without passing the general Matura examination) to obtain an initial vocational qualification. Vocational courses leading to the vocational Matura examination, as a rule, lead to the same qualifications as four-year technical upper secondary programmes which give access to tertiary education as well as to the labour market. (ISCED-P/ISCED-A: 354) 


\section{Examples Group 6: \\ Programmes that span ISCED level 3 and another ISCED level}

Austria-Berufsbildende höhere Schule (Higher technical and vocational college). Five-year vocational programme spanning ISCED level 3 (years 1 to 3 ) and ISCED level 5 (years 4 to 5). The entry requirement for this programme is lower secondary education. The successful completion of the third year is equivalent to a secondary vocational qualification (ISCED level 3) and the final qualification (after five years) is directly equivalent to other qualifications classified at ISCED level 5. It also gives credit for transfer into programmes at ISCED levels 6 or 7 in related fields. The programme qualifies students to exercise a higher-level occupation in the fields of engineering, trade, arts and crafts, tourism, commerce, domestic services, teaching in kindergarten and others. (Years 1 to 3: ISCED-P/ISCED-A: 354; Years 4 to 5: ISCED-P: 554; ISCED-A: 550)

Kazakhstan - Техническое и профессиональное образование по подготовке кадров по массовым профессиям технического и обслужсивающего труда (Technical and vocational training in technical professions). These are three- to four-year programmes following the completion of lower secondary education. They are designed to train skilled workers and provide them with both the certificate of upper secondary level completion (аттестат об общем среднем образовании) after the first two years and a technical and vocational diploma with a technical qualification (диплом о техническом и профессиональном образовании с присвоением технической квалификаиии) following the completion of the third or fourth years. These programmes span ISCED levels 3 and 4 with the first two years classified at ISCED level 3 and the third and fourth years at ISCED level 4. (Years 1 to 2: ISCED-P/ISCED-A: 353; Years 3 to 4: ISCED-P/ISCED-A: 454)

Kazakhstan - Техническое и профессиональное образование по подготовке специалистов среднего звена и предусматриваюшие овладение сложными (смежными) профессиями и практическими навыками выполнения работ во всех отраслях экономики, связанными с высокими технологиями и профессиональной деятельностью (Тесhnical and vocational training of middle managers including mastering complex professions and skills involving a high level of technology). These are four- to five-year programmes following the completion of lower secondary education. The programmes are designed to provide participants with professional knowledge and skills for professions that require some education at tertiary level. They offer both the certificate of upper secondary level completion (аттестат об общем среднем образовании) after the first two years and a technical and vocational diploma with a professional qualification (диплом о техническом и профессиональном образовании с присвоением профессиональной классификаиии) following the completion of the fourth or fifth years. These programmes span ISCED levels 3 and 5 with the first two years classified at ISCED level 3, and the third to fifth years at ISCED level 5. (Years 1 to 2: ISCED-P/ISCED-A: 354; Years 3 to 4/5: ISCED-P: 554; ISCED-A: 550)

\section{Examples Group 7: \\ Programmes leading to partial level completion (or qualifications resulting in partial level completion) [ISCED-P: 342 or 352; ISCED-A: 342 or 352]}

Former Yugoslav Republic of Macedonia $^{3}$ - Strucno osposobuvanje (Vocational training). This is a two-year vocational programme after the end of lower secondary education. Successful completers are awarded a diploma and may continue their studies in the three-year or four-year vocational programmes at the upper secondary level (Sredno obrazovanie - redovno or Sredno obrazovanie - redovno strucno). The latter programme gives direct access to tertiary education. The two-year vocational training programme is designed to give access to other programmes at the upper secondary education level and is therefore part of a sequence of programmes within the ISCED level. (ISCED-P/ ISCED-A: 352)

Lithuania - Profesinio mokymo programa, skirta asmenims, turintiems pagrindinị išsilavinimą ir nesiekiantiems vidurinio išsilavinimo (Vocational education programmes for persons with basic education who are not trying to obtain the maturity certificate - Brandos atestatas - at the end of secondary education). These are two-year programmes designed for successful completers of lower secondary education leading only to a vocational qualification certificate (Profesinés kvalifikacijos pažyméjimas). Successful completers of this programme can continue to the three-year vocational programme (Profesinio mokymo programa, skirta asmenims, turintiems pagrindini išsilavinimą ir siekiantiems vidurinio išsilavinimo) leading also to the maturity certificate (Brandos atestatas). Although the successful completers of the twoyear vocational programme can already join the labour market, the programme is designed to give access to another programme which completes upper secondary education. The two-year programme can thus be treated as part of a sequence of programmes within the ISCED level. (ISCED-P/ISCED-A: 352) 
Malaysia - Menengah Atas (Upper secondary). This is a two-year upper secondary general programme following the completion of lower secondary education. At the end of form 5, the last grade of this programme, students take the Malaysian certificate of education examination (Sijil Pelajaran Malaysia (SPM)) leading to Pra Universiti, which is a twoyear upper secondary programme leading to tertiary education. The SPM is taken after 11 years of education since the start of ISCED level 1. (ISCED-P/ISCED-A: 342)

United Kingdom - General Certificate of Secondary Education (GCSE). This is a two-year general programme after the end of lower secondary education. Until recently it marked the end of compulsory education in the country and hence was the first major exit point from the education system. Students study a number of GCSEs - typically 8 to 10 - in different subjects, each of which is separately assessed both via coursework and terminal examinations. Each subject is assigned a grade from $A^{*}$ (the highest) to $G$ (the lowest) or $U$ (unspecified) in the case of failure. The country considers that five or more subjects passed at grades $A^{*}-C$ represents successful partial level completion of the upper secondarylevel. This is the typical minimum entry requirement to further studies at the upper secondary level - either vocational or general - giving access to tertiary education and/or specific occupations in the labour market. The GCSE programme is in a sequence within the ISCED level and is not the last in the sequence. It represents eleven years of study since the start of primary education and two years of study in upper secondary education. Five or more "passes" at high grades covers a reasonable range of the upper secondary curriculum and therefore is considered as a recognised qualification. The qualification does not give access either to post-secondary non-tertiary or to tertiary education. (ISCED-P/ISCED-A: 342)

\section{Examples Group 8:}

Programmes at ISCED level 3 insufficient for level completion or partial level completion therefore leading to educational attainment at ISCED level 2 [ISCED-P: 341 or 351; ISCED-A: 244 or 254]

Bangladesh - Secondary school vocational certificate. This is a two-year vocational programme that requires the completion of Junior Secondary (ISCED level 2). By the end of the programme, which is offered in both public and nongovernmental technical schools and colleges, graduates receive the Secondary School Vocational Certificate (SSC-Voc). The cumulative duration since the start of ISCED level 1 is only ten years. The programme is therefore insufficient for level completion or partial level completion of ISCED level 3. (ISCED-P: 351; ISCED-A: 254)

Bulgaria - Profesionalno obuchenie za vazrastni - treta stepen PK (Vocational training for adults - third level professional qualification). This vocational programme foreseen for adults has a duration of 1.5-years. It is designed to lead to direct entry to the labour market. (ISCED-P: 351; ISCED-A: 254)

New Zealand - Year 11 - National Certificate of Educational Achievement 1 (NCEA 1). This is the first of three sequential one-year general programmes which make up the typical general pathway within upper secondary education. The NCEA 1 marks the first major exit point from the education system. The NCEA 1 is part of a sequence of programmes representing eleven years of study since the start of primary education but only one year of study in upper secondary education. The qualification does not give access either to post-secondary non-tertiary or to tertiary education. (ISCED-P: 341; ISCED-A: 244)

Zambia - Trade Test Level /l Certificate. This vocational programme is offered to learners who complete lower secondary education and have at least one year's working experience or learners who hold a primary education certificate and have at least three years' working experience. The duration of the programme varies from six months to one year which is insufficient for ISCED 3 level completion. (ISCED-P: 351; ISCED-A: 254)

Examples Group 9:

Vocational programmes/qualifications giving access to tertiary education [ISCED-P: 354; ISCED-A: 354]

Japan - Koutou senmon gakko (Colleges of Technology, years 1-3). Entrance into Koutou senmon gakko is possible after completion of compulsory education. The purpose of the programme is to nurture promising practical engineers and to study general education through a five-year programme (first 3 years: ISCED-P 354, fourth and fifth years: ISCED-P 554). Most of the students who have completed the first three years of Koutou senmon gakko will advance to the fourth year (ISCED-P 554), but students will also have the qualification to enter universities (ISCED 6 or 766 ). (First three years of Koutou senmon gakko: ISCED-P/ISCED-A: 354) 
Kuwait - برنامج دبلوم التمريض (Nursing diploma programme). This vocational programme requires the successful completion of at least Grade 9, which is the last grade of lower secondary education. Although the theoretical entrance age is 15 years, the typical entrance age is 17 years due to multiple repetitions. The programme, which lasts three years, is considered a full completion of the level. Upon graduation, participants can proceed to tertiary education. (ISCED-P: 354; ISCED-A: 354)

Netherlands - WEB-middenkaderopleiding, voltijd bol en bbl (Vocational education, middle management training (level 4); full-time school-based and dual-system education programmes). This is a three-year vocational programme following successful completion of, typically, a four-year pre-vocational lower secondary education programme (Voorbereidend middelbaar beroepsonderwijs (VMBO) (beroepsgerichte, gemengde en theoretische leerwegen)). A parttime programme leading to the same qualification (MBO niv.4: middenkaderfunctionaris) also exists but participants are generally older than in the full-time programme. (ISCED-P/ISCED-A: 354)

\section{Examples Group 10:}

Programmes/qualifications leading to (full) completion of upper secondary education but not giving access to tertiary education [ISCED-P: 343 or 353; ISCED-A: 343 or 353]

Afghanistan - Talimate Takhniki wa Maslaki (Technical and Vocational Education (Grades 10 to 14)). The theoretical duration of this vocational programme is five years following the successful completion of Grade 9 (ISCED 2). By the end of the programme, graduates are awarded the Shahadat Naama (certificate), which provides direct access to the labour market and to programmes at the tertiary level. The first three grades of the programme are classified at the upper secondary level. (Grades 10 to 12: ISCED-P/ISCED-A: 353; Grades 13 to 14: ISCED-P/ISCED-A: 454)

Germany - Beamtenausbildung (mittlerer Dienst) (Training for Civil Servants (Medium Level)). This programme has a duration of two years and provides training for future civil servants at middle management level. It requires the intermediate school certificate or a recognised equivalent for admission. The programme is offered both in institutions of public administration at all regional levels (Bund, Länder, Regierungsbezirke, Kreise, Gemeinden) and in special schools for public administration. Graduates take up employment in the civil service upon completion of the programme. The programme does not give access to tertiary education. (ISCED-P/ISCED-A: 353)

Israel - Batey sefer taasiyatiim le hanihim, misrad ha-kalkala, tlat shnati (Apprenticeship and industrial schools, Ministry of Economy, three-year education). This is a three-year vocational programme following successful completion of lower secondary education. Successful completers can continue their studies in short preparatory programmes of 7 to 10 months for engineers or similar professions (Mechina kdam handasaim) though most go directly to the labour market. A small number of successful completers continue their studies at the post-secondary non-tertiary level. (ISCED-P/ ISCED-A: 353)

Seychelles - Upper secondary education programme. This is a two-year upper secondary general programme following the completion of lower secondary education. Upon completion of the programme, students obtain the Secondary Five National Examination Certificate or IGCSE (Cambridge) or DELF Scolaire (Diplôme d'Études en Langue Française), which give direct access to post-secondary non-tertiary education but not to tertiary education. (ISCED-P/ISCED-A: 343)

\section{Examples Group 11: \\ Programmes leading to more than one qualification (and their resulting attainment levels) [Any ISCED-P or ISCED-A codes at ISCED level 3]}

Poland - Trzyletnie liceum ogólnokształcące (General upper secondary school). This is a three-year programme following successful completion of lower secondary education. It leads to a school-leaving certificate (Świadectwo ukończenia liceum ogólnokształcącego (wykształcenie średnie)) awarded to all students who successfully complete the programme. Students wishing to go to university may also take a matriculation certificate (Matura - świadectwo dojrzałości). Entry to university is not possible without the Matura certificate. The programme is classified as ISCED-P 344 as it is a general programme designed to give access to university (and a majority of students aim to obtain the Matura). However, the educational attainment of successful completers depends on the qualifications gained at the end of the programme. The school-leaving certificate is not sufficient for entry to tertiary education so it is classified as ISCED-A 343 whereas the Matura certificate is coded as ISCED-A 344. (ISCED-P: 344; ISCED-A: 343 or 344) 


\section{Notes}

1. Paragraph numbers are references to the main ISCED 2011 classification document. See more details in the Reader's Guide.

2. The UNESCO Institute of Statistics (UIS) and the European Union (EU) use "Slovakia" as the official name of "Slovak Republic".

3. The UNESCO Institute of Statistics (UIS) uses "The former Yugoslav Republic of Macedonia" as the official name of "Former Yugoslav Republic of Macedonia". 


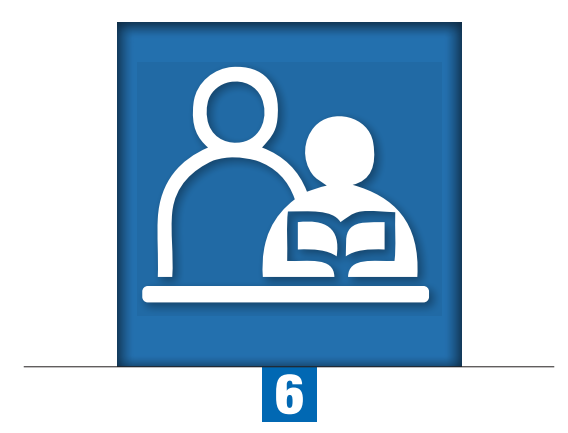

\section{Chapter 6}

\section{ISCED 2011 level 4:}

\section{Post-secondary non-tertiary education}

Programmes at the post-secondary non-tertiary education level are not significantly more complex than those at the upper secondary level. They generally serve to broaden rather than deepen the knowledge, skills and competencies already gained through successful (full) level completion of upper secondary education. They may either be designed to increase options for participants in the labour market or for further studies at the tertiary level or both.

Usually, programmes at ISCED level 4 are vocationally oriented. They may be referred to in many ways, for example: technician diploma, primary professional education or préparation aux carrières administratives. For international comparability purposes, the term 'post-secondary non-tertiary education' is used to label ISCED level 4. 


\section{DESCRIPTION}

\section{Definition}

$(\S 185)^{1}$ Post-secondary non-tertiary education provides learning experiences building on secondary education, preparing for labour market entry as well as tertiary education. It aims at the individual acquisition of knowledge, skills and competencies lower than the level of complexity characteristic of tertiary education. Programmes at ISCED level 4, or post-secondary non-tertiary education, are typically designed to provide individuals who completed ISCED level 3 with non-tertiary qualifications required for progression to tertiary education or for employment when their ISCED level 3 qualification does not grant such access. For example, graduates from general ISCED level 3 programmes may choose to complete a non-tertiary vocational qualification; or graduates from vocational ISCED 3 programmes may choose to increase their level of qualifications or specialise further. The content of ISCED level 4 programmes is not sufficiently complex to be regarded as tertiary education, although it is clearly post-secondary.

(\$187) Usually, programmes at this level are designed for direct labour market entry. In some education systems, there are general programmes at this level. Such programmes typically target students who have completed ISCED level 3 but who want to increase their opportunities to enter tertiary education.

\section{Classification criteria (\$189)}

\section{Main criteria}

a) Orientation

(\$190) ISCED level 4 programmes are not considered to be tertiary education and are typically vocational and terminal programmes that prepare for the labour market. General programmes at this level can also exist in some education systems. Programmes designed to review the content of ISCED level 3 programmes - for example, with the aim of preparing students for tertiary education entrance examinations - should be included in ISCED level 3.

b) Complexity of content higher than ISCED level 3 and below the level of tertiary education

(§191) ISCED level 4 programmes often serve to broaden - rather than deepen - the knowledge, skills and competencies of participants who have completed a programme at ISCED level 3. Programmes are often not significantly more advanced than programmes at ISCED level 3 but the content is typically more specialised or detailed than at the upper secondary level of education. Programmes are clearly less advanced than at the tertiary level and can be provided in a variety of institutional settings, not only those considered as post-secondary nontertiary institutions.

c) Entry requirements

(§186) The completion of an ISCED level 3 programme [with full completion of the level] is required to enter ISCED level 4 programmes. However, these entry requirements may be lower than for tertiary programmes at ISCED level 5,6 or 7 .

\section{Subsidiary criteria}

None. 


\section{Complementary dimensions}

(§193) Two dimensions may differentiate programmes at ISCED level 4:

(§194) Programme orientation:

- General; and

- Vocational

(\$195) Level completion and access to higher ISCED levels;

- No completion of ISCED level 4: modules or stages of programmes which are too short for level completion. These do not give access to first tertiary education programmes at ISCED level 5,6 or 7 . Successful completion of such modules or stages does not count as completion of ISCED level 4.

- Completion of ISCED level 4 without direct access to first tertiary programmes at ISCED level 5, 6 or 7: programmes designed primarily for direct labour market entry.

- Completion of ISCED level 4 with direct access to first tertiary programmes at ISCED level 5, 6 or 7: programmes designed primarily to expand access to tertiary education.

(\$198) For educational attainment, recognized intermediate qualifications from successful completion of a stage of an ISCED level 5 programme which are not considered as sufficient for completion of ISCED level 5 are classified at ISCED level 4.

\section{CORRESPONDENCE BETWEEN ISCED 2011 AND ISCED 1997}

(§279) ISCED 2011 level 4, post-secondary non-tertiary education, corresponds largely to level 4 in ISCED 1997. However, programmes leading to a qualification equivalent to upper secondary general education are classified as level 3 in ISCED 2011, while they were often classified as level 4 in ISCED 1997. In addition, due to the clarification of criteria and subsidiary criteria, ISCED 2011 may be implemented differently than ISCED 1997. Such differences may affect time series data for some countries.

The complementary dimensions for ISCED level 4 are different in the latest version of ISCED.

a) Programme orientation

ISCED 1997 defined three types of orientation: general, pre-vocational and vocational. In ISCED 2011 there are only two orientations at ISCED level 4: general and vocational. Programmes previously classified as pre-vocational (in ISCED 1997) do not provide labour market-relevant qualifications and are now mainly classified as general education.

b) Level completion and programme destination

ISCED 1997 classified programmes according to the programmes and levels to which they were designed to lead (the programme destination). At ISCED level 4, two destinations were defined in ISCED 1997:

$$
\begin{aligned}
& A=\text { programmes that prepare for entry to tertiary education (ISCED } 1997 \text { level 5); } \\
& B \text { = programmes not giving access to tertiary education (primarily designed for direct labour market entry). }
\end{aligned}
$$

ISCED 2011 classifies programmes according to the type of completion of the level and access to other levels. ISCED 1997 destination A is directly equivalent to the ISCED 2011 sub-category (full) completion of ISCED 2011 level 4 with direct access to tertiary education. ISCED 1997 destination B is sub-divided into two sub-categories in ISCED 2011:

- (full) completion of ISCED 2011 level 4 with no direct access to tertiary education; and

- insufficient for level completion of ISCED 2011 level 4. 


\section{GUIDELINES FOR CLASSIFYING PROGRAMMES AND THEIR RELATED RECOGNISED QUALIFICATIONS AT ISCED LEVEL 4}

Programmes at the post-secondary non-tertiary level are not significantly more complex than those at the upper secondary level. They generally serve to broaden rather than deepen the knowledge, skills and competencies already gained through successful (full) level completion of upper secondary education. They may either be designed to increase options for participants in the labour market or for further studies at the tertiary level or both.

Programmes designed to lead to additional upper secondary qualifications or to provide access to additional occupations than studied at the upper secondary level should be classified at ISCED level 4. This includes second-cycle vocational programmes resulting in a total cumulative duration of study since the start of ISCED level 3 which is significantly longer than the general upper secondary programme giving direct access to first degrees at ISCED levels 6 or 7 . Vocational programmes offered in parallel with other upper secondary programmes should normally be classified at ISCED level 3.

Usually, programmes at ISCED level 4 are vocationally oriented and offer to successful completers of upper secondary education training in the knowledge, skills and competencies required for a specific occupation. In many cases these vocational post-secondary non-tertiary programmes are designed solely to lead to the labour market, without granting access to tertiary education. These programmes are classified as ISCED-P: 453; ISCED-A: 453 (see Examples Group 1).

Some education systems also have general post-secondary non-tertiary education programmes. These programmes usually target students who have completed upper secondary education but wish to increase their opportunities to enter tertiary education (\$187). The students may have previously completed a vocational upper secondary programme and therefore wish to obtain the general secondary education qualification. Alternatively, they may have completed a general secondary education but wish to broaden their knowledge in some specific subjects or fields in order to increase their chances in the application process for tertiary education. These programmes are classified as ISCED-P: 444; ISCED-A: 444 (see Examples Group 2).

Second chance or re-integration programmes designed for those who did not successfully complete upper secondary education, or to improve grades in qualifications already gained from upper secondary education or to change streams usually from general to vocational - to enter programmes or occupations at the upper secondary level for which existing upper secondary-level qualifications do not provide access should be classified at ISCED level 3. (See the ISCED level 3 chapter for examples.)

Some ISCED 4 vocational programmes may also be designed to give access to tertiary education when a student did not previously have this access, or may enhance and broaden the opportunities for studies in tertiary education although the student's previous upper secondary qualification already gave some access to tertiary education. Still other ISCED 4 programmes may give access both to the labour market and to tertiary education. Assuming the other ISCED 4 criteria are met, these programmes could all be considered as completion of ISCED 4 with access to tertiary education (see Examples Group 3).

It may at times be difficult to distinguish whether a post-secondary non-tertiary programme gives access to tertiary education for the first time; if it enhances access opportunities when the student already had access to tertiary education; or if the programme is not designed to give further access to tertiary education even if the previous qualification required to enter the programme already gave access to tertiary education (see Examples Group 4). A possible guideline for these cases is presented below.

\begin{tabular}{l|l|l}
\hline $\begin{array}{l}\text { Access from ISCED } 3 \text { programme } \\
\text { required for entry }\end{array}$ & Access from ISCED 4 programme & Third digit coding (ISCED-P and ISCED-A) \\
\hline $\begin{array}{l}\text { No direct access to tertiary } \\
\text { education }\end{array}$ & $\begin{array}{l}\text { First time direct access to tertiary } \\
\text { education }\end{array}$ & $\begin{array}{l}444 / 454-\text { completion with direct access } \\
\text { to tertiary education }\end{array}$ \\
\hline Direct access to tertiary education & $\begin{array}{l}\text { Broader direct access to tertiary } \\
\text { education }\end{array}$ & $\begin{array}{l}444 / 454-\text { completion with direct access } \\
\text { to tertiary education }\end{array}$ \\
\hline Direct access to tertiary education & $\begin{array}{l}\text { No further or broader access to tertiary } \\
\text { education }\end{array}$ & $\begin{array}{l}\text { ISCED-P: } 443 / 453-\text { completion with no } \\
\text { direct access to tertiary ISCED-A: } 444 / 454- \\
\text { as the student already had access to tertiary } \\
\text { education }\end{array}$ \\
\hline
\end{tabular}


The entry requirement for ISCED 4 programmes is successful completion of ISCED 3. This means successful completion of an upper secondary education programme that is classified as (full) level completion of upper secondary education (i.e. ISCED-P/ISCED-A: 343, 353, 344 or 354). Programmes following an ISCED 3 programme but that do not lead to completion of the level should be classified at ISCED level 3.

ISCED level 4 programmes are often designed for participants beyond the age for upper secondary education. The entry requirements may include both education qualifications and a period of relevant work experience (see Examples Group 5).

ISCED level 4 programmes typically have a full-time equivalent duration between six months and two years. Programmes of more than two years in duration may be classified at ISCED level 4. However, some assessment should be made of the level of complexity of programmes which are significantly longer than two years. The classification of very long programmes at ISCED level 4 needs to be given careful consideration. In such cases, the key criterion distinguishing post-secondary non-tertiary (ISCED level 4) from short-cycle tertiary education (ISCED level 5) is the depth of complexity of the programme (see Examples Group 6).

Where programmes of different durations lead to the same qualification, or to qualifications that are recognised as equivalent to one another, they should normally be classified the same ISCED level. However, since ISCED level 4 is not significantly more advanced than some programmes at ISCED level 3 - in particular second-cycle programmes or those leading to other qualifications than those already obtained at upper secondary level - may result in qualifications that are awarded to other participants in some upper secondary programmes. The equivalence of the qualifications is not a sufficient reason to classify a programme at ISCED level 3. On the other hand, some ISCED level 4 qualifications are recognised nationally as being 'higher' than those offered at ISCED level 3. Where this is the case, all programmes leading to these 'higher' qualifications should be seen either as programmes spanning ISCED levels 3 and 4 or as ISCED level 4 programmes.

Post-secondary non-tertiary programmes can be labelled in many ways (see §188). However, it is important to classify the programme not by name or institution but according to the level of complexity of content, from an international perspective. Similarly, it should be noted that ISCED level 4 programmes can be provided in a variety of institutional settings, not only those considered as post-secondary non-tertiary institutions $(\$ 191,52)$. Therefore, the type of education provider or institution should not be used as a main criterion to distinguish ISCED level 4 from tertiary or even secondary education (see Examples Group 7).

\section{Distinction between ISCED level $\mathbf{4}$ and ISCED level $\mathbf{5}$}

The key criterion distinguishing post-secondary non-tertiary and short-cycle tertiary education is the complexity of the programme content. Programmes at both levels require full completion of upper secondary education for entry. ISCED level 4 programmes broaden the knowledge of students in a certain field. However they are not significantly more advanced than programmes at ISCED level 3. ISCED level 5 is a significant step higher than ISCED level 3. Programmes at ISCED level 5 deepen the knowledge, skills and competencies of participants in a given domain.

Qualifications obtained at ISCED level 5 are considered to be at a higher level than those from ISCED level 4. Short-cycle tertiary education programmes may give credit for transfer into first tertiary degree ISCED level 6 or 7 programmes. Upon completion of ISCED level 5, individuals may have direct access to these first tertiary degree programmes and be exempted from certain courses or modules at these levels. ISCED level 4 programmes lead to qualifications that are only slightly higher in level than ISCED 3 qualifications, and in some cases they even lead to the same qualifications as ISCED 3. They do not give credit towards study at the tertiary level.

\section{EDUCATIONAL ATTAINMENT AT ISCED LEVEL 4}

Educational attainment at ISCED level 4 requires the successful completion - leading to a recognised qualification - of a programme representing a minimum cumulative duration at ISCED level 4 of at least 6 months.

ISCED level 4 can also include modules or stages of programmes which are less than half a year in duration and therefore too short for completion of the level. The successful completion of such modules or stages of programmes would be considered at ISCED level 3 in terms of educational attainment.

Similarly, the qualifications resulting from successful completion of programmes classified at ISCED level 5 but which do not meet the criteria for completion of the level would be classified with an educational attainment of ISCED level 4, even if this level does not exist in the country. (See Examples Group 7 in the ISCED level 5 chapter) 


\section{EXAMPLES OF PROGRAMMES AND QUALIFICATIONS CLASSIFIED AT ISCED LEVEL 4}

(§188) Programmes classified at ISCED level 4 may be referred to in many ways, for example: technician diploma, primary professional education, préparation aux carrières administratives. For international comparability purposes, the term 'post-secondary non-tertiary education' is used to label ISCED level 4.

Examples Group 1:
Vocational ISCED level 4 programmes sufficient for level completion, designed to give entry to the labour
market (without direct access to tertiary education) [ISCED-P: 453; ISCED-A: 453]

Egypt - السنتين الأخيرتين من البرامج التقنية لخمس سنوات (The last two years of the five-year technical programme). This long vocational programme requires the completion of the preparatory education level (ISCED 2). At the end of the five-year programme, graduates are awarded a first technical diploma, which leads only to the labour market. A similar diploma is also awarded following the completion of another two-year post-secondary vocational programme (already classified at ISCED 4). For international data reporting, this long programme is considered as spanning ISCED levels 3 and 4. The first three grades are classified as full completion of upper secondary without access to tertiary education (ISCED-P/ISCED-A: 353) while the last two years are considered as post-secondary non-tertiary education without access to tertiary education. (ISCED-P/ISCED-A: 453)

Ireland - Teagasc Advanced Certificate in Agriculture. This vocational training programme may range between 1.5-3 years and three years in duration. The minimum entry requirement is upper secondary education. Successful completion of the programme gives a Teagasc (Irish Agriculture and Food Development Authority) Advanced Certificate in Agriculture, leading directly to the labour market. (ISCED-P/ISCED-A: 453)

Spain - Certificados de Profesionalidad de nivel 3 (Professional Certificate Level 3 - third level professional qualification). These are programmes preparing for the labour market. The general entry requirement for these programmes is the completion of upper secondary education. Access is also possible for those who can demonstrate the ability to handle these programmes, or those who have a Certificado de Profesionalidad de nivel 2 qualification in the same field of study. The programme duration ranges from six months to one year (between 350 and 1,110 hours of study and supervised teaching/training). (ISCED-P/ISCED-A: 453)

\section{Examples Group 2:}

General ISCED level 4 programmes sufficient for level completion, designed to enhance opportunities to enter tertiary education [ISCED-P: 444; ISCED-A: 444]

Canada - Post-secondary short general pre-university diploma programmes. The programmes have a duration of up to two years following the completion of upper secondary education. They are considered as qualifying programmes in preparation for undergraduate studies at university. Following completion of these diploma programmes, students may apply for Bachelor's programmes (i.e. ISCED level 6). (ISCED-P/ISCED-A: 444)

Germany - Sekundarbereich II, Berufsoberschule (Upper secondary vocational schools). In the Berufsoberschule, the knowledge, skills and competencies acquired by students during their initial vocational education and training are taken as the basis for an extended general and in-depth subject-related theoretical education, which enables students to pursue a course in higher education. The three- to four-year courses of education lead to a double qualification: both a vocational qualification (e.g. the assistant occupations or vocational qualifications in a number of recognised occupations requiring formal training) and a higher education entrance qualification. The Berufsoberschule provides two years of fulltime education and leads to the Fachgebundene Hochschulreife. Students can obtain the Allgemeine Hochschulreife by proving their proficiency in a second foreign language. (ISCED-P/ISCED-A: 444)

Israel - Mechina kdam akademit (Pre-academic preparatory programme). These are one-year general programmes designed for students who have completed upper secondary education programmes that do not give access to tertiary education, in order to enhance opportunities to enter tertiary education. Successful completion of the programme results in the Mechina certificate, which replaces the matriculation certificate for the purpose of acceptance to studies at the tertiary level. (ISCED-P/ISCED-A: 444) 
Israel - Mechina kdam handasaim (Preparatory programmes for practical engineers). These 7- to 10-month programmes are designed for students who have completed upper secondary education and who wish to pursue tertiary-level training in engineering. Successful completion of the programme results in the qualification Teudat Sium Mechinat Handesaim (completion of post-secondary non-tertiary vocational education), which gives access to short-cycle tertiary education programmes in engineering (Mahat) provided by the Ministry of Economy. (ISCED-P/ISCED-A: 444)

Oman - السنة التأسيسية (Foundation year). This general post-secondary programme is offered to students who have completed upper secondary education (with access to tertiary education) but who wish to widen their study options at the tertiary level. Typical entrance age to this one-year programme is 19 years. Upon completion, graduates receive a foundation certificate (ثهادة إنجاز السنة التأسيسية), which also gives access to tertiary education. (ISCED -P/ICSED-A: 444)

Qatar - البرنامج التأسيسي (Foundation programme). This is a one-year post-secondary programme that is offered to students who have completed upper secondary education (with access to tertiary education) but who wish to broaden their study options at the tertiary level. The programme, which is offered in universities, has a duration of one year. Upon completion, graduates receives a completion certificate, which also gives access to tertiary education. (ISCED -P/ISCED-A: 444)

Switzerland - Passerellenlehrgang/passerelle/passerella (Preparatory course for university for holders of the vocational baccalaureate). These are one-year general programmes preparing graduates of vocational upper secondary education for admission to study programmes at the tertiary level. Upon successful completion of the programme, students obtain a university aptitude certification (Passerellenzeugnis/Certificate de passerelle/Certificado de passerella) which give access to Bachelor's level programmes. (ISCED-P/ISCED-A: 444)

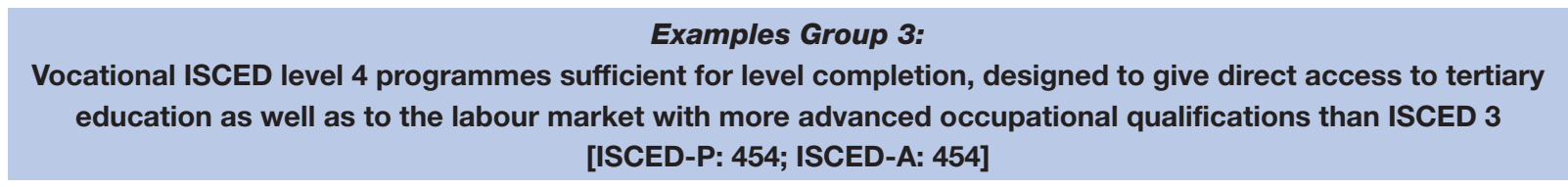

Canada - Career, technical or professional training programmes. Students typically enter these one- to two-year programmes at age 18 following completion of upper secondary education. The vocationally-oriented programmes lead to attestations or certificates for specific occupations. Completion of the programmes also gives access to short-cycle tertiary education programmes. (ISCED-P/ISCED-A: 454)

Estonia - Kutseõpe keskariduse basil (Vocational education based on secondary education). These are vocational programmes designed for students who have completed upper secondary education. The typical entrance age is 19 years and the duration may range between 1-2.5 years. Upon completion, students receive a Certificate of Vocational Secondary Education Based on Secondary Education. The programme also gives access to Bachelor's study programmes (Bakalaureuseõpe). (ISCED-P/ISCED-A: 454)

France - Préparation à l'entrée d'une formation sélective de niveau BTS (Various tertiary programmes including preparatory courses for competitive entrance examinations). These are one-year programmes for students who have completed upper secondary education and who wish to enter selective vocational training programmes at short-cycle tertiary education. The programmes offer training in a diversity of professional fields. The programmes prepare students to enter into high-level paramedical and social service schools (écoles paramédicales et sociales), which are at the level of the Brevet de technicien supérieur (BTS) (i.e. ISCED level 5). (ISCED-P/ISCED-A: 454)

Germany-Berufsschulen/Duales System (Dual system second cycle programme). This is a special form of apprenticeship (second cycle) which comprises education and training both at a vocational school and in an enterprise. Students must have successfully completed upper secondary education, either a general programme with university entrance qualification or a vocational programme (either in the dual system leading to a Lehrabschluss or a full-time vocational training programme at a specialised vocational school), in order to enter this 3- or 3.5-year programme. Graduates qualify for further studies in Fachschulen or can enter directly into the labour market. (ISCED-P/ISCED-A: 454)

Morocco - مستوى التقني المتخصص (Specialised technician). This is a two-year post-secondary programme which requires the successful completion of upper secondary education. It aims at preparing technicians in various specialised occupations. By the end of this vocational programme, participants are awarded the Diplôme de Technicien Spécialisé (DTS) (Diploma of specialised technician). In addition to the labour market, this diploma also gives access to tertiary education. (ISCED-P/ISCED-A: 454) 
Netherlands - WEB-specialistenopleiding, bol en bbl (Vocational education, specialist training, level 4). These postsecondary vocational programmes are full-time, school-based and dual-system education programmes. Students typically enter these one-year programmes at age 19 following completion of upper secondary education (without access to tertiary). Upon successful completion of the programme, students receive the qualification of secondary vocational education, specialist level (MBO niv.4: specialist), which also gives access to tertiary education. (ISCED-P/ISCED-A: 454)

Seychelles - Diploma programmes. These are three-year vocational programmes offered after the completion of the first year of study of the two-year Advanced Certificate A-level programme (ISCED 344). Graduates from the diploma programme are awarded a diploma certificate which provides direct access to tertiary education. (ISCED-P/ISCED-A: 454)

\section{Examples Group 4: \\ Vocational ISCED level 4 programmes sufficient for level completion, designed to give access \\ to the labour market, but entry requirements already included access to tertiary education [ISCED-P: 453 or 454; ISCED-A: 454]}

Brazil - Educação profissional de ensino médio (subsequente) (Professional education at the upper secondary level (further education)). These programmes are designed for students who have already completed an ISCED level 3 programme and wish to obtain a vocational education, designed for labour market entry. The programmes last at least 800 hours (between 8 and 18 months). Students in these programmes are usually older than those in ISCED 3 programmes and are looking for a specific vocational education in order to get a better position in the labour market. Many students are already employed but aim to become more specialised in their field. Students who enter this programme already have access to tertiary education through their previous ISCED 3 qualification (upper secondary education ensino médio). However this vocational programme is designed specifically for the labour market and does not provide additional preparation or access to the tertiary level beyond that acquired at ISCED 3. (ISCED-P: 453; ISCED-A: 454)

Greece - Diploma epagematikis katartisis epipedou metadefterovathmias epagelmatikis katarisis (Diploma of vocational training. These five-semester vocational programmes (four semesters of lessons and one semester of apprenticeship) are offered by the Institutes of Vocational Training (Institouto Epagelmatikis Katartisis - IEK) and require the completion of upper secondary education for entry. The diploma obtained upon graduation from these programmes does not provide access to tertiary education or university institutions. It is designed for entry to the job market as a skilled technician of a higher level. Among the entry requirements is the successful completion of upper secondary school (lyceia), either general or vocational, which gives access to ISCED level 6 (subject to general university entrance exams). (ISCED-P: 453; ISCED-A; 453 or 454)

Portugal - Ensino pós-secundário não superior, Curso de Especialização Tecnológica (Post-secondary non-tertiary technological specialisation course). These vocationally-oriented programmes have a duration of 1-1.5 years and lead to the Especialização Tecnológica diploma. The technological specialisation courses are post-secondary non-tertiary training courses which prepare young people and adults to perform qualified jobs, in order to facilitate entry into the labour market. The courses have components of training in school and in the workplace. The minimum requirement to enter these programmes is the successful completion of upper secondary education. Successful completion of these programmes gives access to first tertiary degree programmes at ISCED levels 6 and 7. (ISCED-P/ISCED-A: 454)

\section{Examples Group 5:}

Vocational ISCED level 4 programmes sufficient for level completion, with relevant work experience also considered in entry requirements [ISCED-P: 453 or 454; ISCED-A: 453 or 454]

Finland - Erikoisammattitutkinto (Vocational programmes preparing for specialist vocational qualifications). These are programmes preparing for a competence-based qualification or skills examination which is taken usually after some years of work experience (for example in crafts or technical skills). While students usually participate in these programmes in order to prepare for the qualification, the qualification can also be attained based on working skills rather than the completion of previous studies. Participants in these programmes have usually completed upper secondary education or have equivalent skills. Upon successful completion of these programmes, students also have access to tertiary education. (ISCED-P/ISCED-A: 454)

Norway - Halårig til ettårig fagskoleutdanning (0.5- to 1-year vocational college programmes). These programmes are designed for direct labour market entry to meet a series of specialised vocational needs. Often, they constitute a further 
specialisation to craft's or journeyman's certificates. Sometimes, however, they are offered in fields not provided at the ISCED 3 level. The admission requirement is successful completion of upper secondary education or training (ISCED level 3). (ISCED-P: 453; ISCED-A: 453)

\section{Examples Group 6:}

Vocational ISCED level 4 programmes of more than two years in duration but where the content is below the tertiary level [ISCED-P: 453 or 454; ISCED-A: 453 or 454]

Guinea-Bissau - Treinamento (formação) de professores de ensino secundário geral (Teacher training for general secondary). This programme has a duration of three years following the completion of upper secondary education. It aims at preparing qualified upper secondary teachers. By the end of the programme, participants are awarded a general secondary teaching diploma (Diploma de ensino secundário geral), which in addition to the labour market also gives access to tertiary education. The programme is classified as post-secondary non-tertiary education (ISCED 4) as nationally it is considered lower than tertiary education. (ISCED-P/ISCED-A: 454)

Poland - Policealne studium wokalno-aktorskie (Post-secondary vocal and stage performance school). This is a vocational programme at ISCED level 4 that prepares students for specific artistic occupations and leads to the award of a post-secondary school-leaving certificate. According to the Regulation of the Ministry of Culture and National Heritage, from the school year 2014/2015 onwards, education offered in policealne stadium wokalno-aktorskie is organised in a three-year cycle of study. (ISCED-P/ISCED-A: 453)

\section{Examples Group 7: \\ ISCED level 4 programmes offered in non-typical institutions for post-secondary non-tertiary education [Any ISCED-P or ISCED-A codes at ISCED level 4]}

Czech Republic - Další vzdělávání na vysoké škole: pro absolventy SŠ (Universities: the second qualification for graduates from upper secondary education). These are post-secondary general courses designed for students who have completed upper secondary education (with access to tertiary education) and are offered in universities. Students enter at age 19 or older, and the duration is one year. Upon completion, students receive a certificate (osvědsčeni). The programme also gives access to tertiary education. (ISCED-P/ISCED-A: 444)

Czech Republic - Pomaturitní studium (Post-secondary courses, vocational type). These are post-secondary vocational courses designed for students who have completed upper secondary education (with access to tertiary education). The programme is offered at secondary schools. The typical entrance age is 19, and the duration is one year. Upon completion, students receive a certificate (osvědsčeni). The programme also gives access to tertiary education. (ISCED-P/ISCED-A: 454)

Spain - Títulos propios de Universidad de menos de 2 años (Specific degrees of universities, less than two years). These diverse, short post-secondary programmes are offered in universities and do not lead to national university degrees. The duration ranges between 0.5-1 year. Students need to have completed upper secondary education in order to enter these vocational programmes. (ISCED-P/ISCED-A: 453)

\section{Note}

1. Paragraph numbers are references to the main ISCED 2011 classification document. See more details in the Reader's Guide. 



\section{PART III \\ ISCED LEVELS 5 TO 8: TERTIARY EDUCATION}

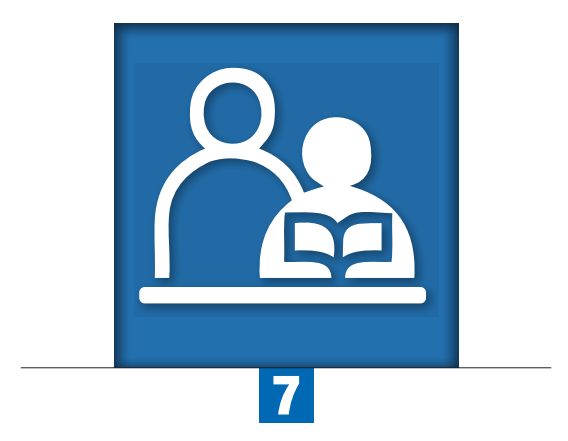

Chapter 7

\section{Overview of ISCED 2011 tertiary education levels}

Tertiary education builds on secondary education, providing learning activities in specialised fields of study. It aims at learning at a high level of complexity and specialisation. Tertiary education includes what is commonly understood as academic education but also includes advanced vocational or professional education.

There is usually a clear hierarchy between qualifications granted by tertiary education programmes. It comprises ISCED levels 5 (short-cycle tertiary education), 6 (Bachelor's or equivalent level), 7 (Master's or equivalent level) and 8 (doctoral or equivalent level). The content of programmes at the tertiary level is more complex and advanced than in lower ISCED levels. 


\section{DESCRIPTION}

\section{Definition}

$(\S 200)^{1}$ Tertiary education builds on secondary education providing learning activities in specialised fields of study. It aims at learning at a high level of complexity and specialisation. Tertiary education includes what is commonly understood as academic education but also includes advanced vocational or professional education. It comprises ISCED levels 5, 6, 7 and 8, which are labelled as short-cycle tertiary education, Bachelor's or equivalent level, Master's or equivalent level, and doctoral or equivalent level, respectively. The content of programmes at the tertiary level is more complex and advanced than in lower ISCED levels.

(§201) First programmes at ISCED level 5, 6 or 7 require the successful completion of ISCED level 3 programmes that give direct access to first tertiary education programmes. Access may also be possible from ISCED level 4. In addition to qualification requirements, admission into education programmes at these levels may depend on subject choice and/or grades achieved at ISCED level 3 or 4 . Further, it may be necessary to take and succeed in entrance examinations.

(§205) The successful completion of ISCED level 7 is usually required for entry into ISCED level 8 (see figure 1).

(§203) There is usually a clear hierarchy between qualifications granted by tertiary education programmes. However, unlike programmes at ISCED levels 1, 2, 3 and 4, national programmes at ISCED levels 5, 6 and 7 can exist in parallel rather than as one ISCED level building sequentially on another.

Figure 7.1 illustrates the groups of tertiary education programmes (which will be described in more detail in the following chapters) and the pathways between them. These categories are:

- Short-cycle tertiary education programmes at ISCED level 5 (see group 5);

- First tertiary degree programmes with a cumulative theoretical duration (at tertiary level) of three to four years, at ISCED level 6 (Bachelor's or equivalent level) (see group 665);

- Long first tertiary degree programmes with a cumulative theoretical duration (at tertiary level) of more than four years, at ISCED level 6 (Bachelor's or equivalent level) (see group 666);

- Second or further tertiary degree programmes, following successful completion of a Bachelor's or equivalent programme, at ISCED level 6 (Bachelor's or equivalent level) (see group 667);

- Long first tertiary degree programmes with a cumulative theoretical duration (at tertiary level) of at least five years (that does not require prior tertiary education), at ISCED level 7 (Master's or equivalent level) (see group 766);

- Second or further tertiary degree programmes, following successful completion of a Bachelor's or equivalent programme, at ISCED level 7 (Master's or equivalent level) (see group 767);

- Second or further degree programmes, following successful completion of another Master's or equivalent programme, at ISCED level 7 (Master's or equivalent level) (see group 768); and

- Doctoral or equivalent programmes at ISCED level 8 (see group 8). 
- Figure 7.1 .

Tertiary education pathways in ISCED 2011

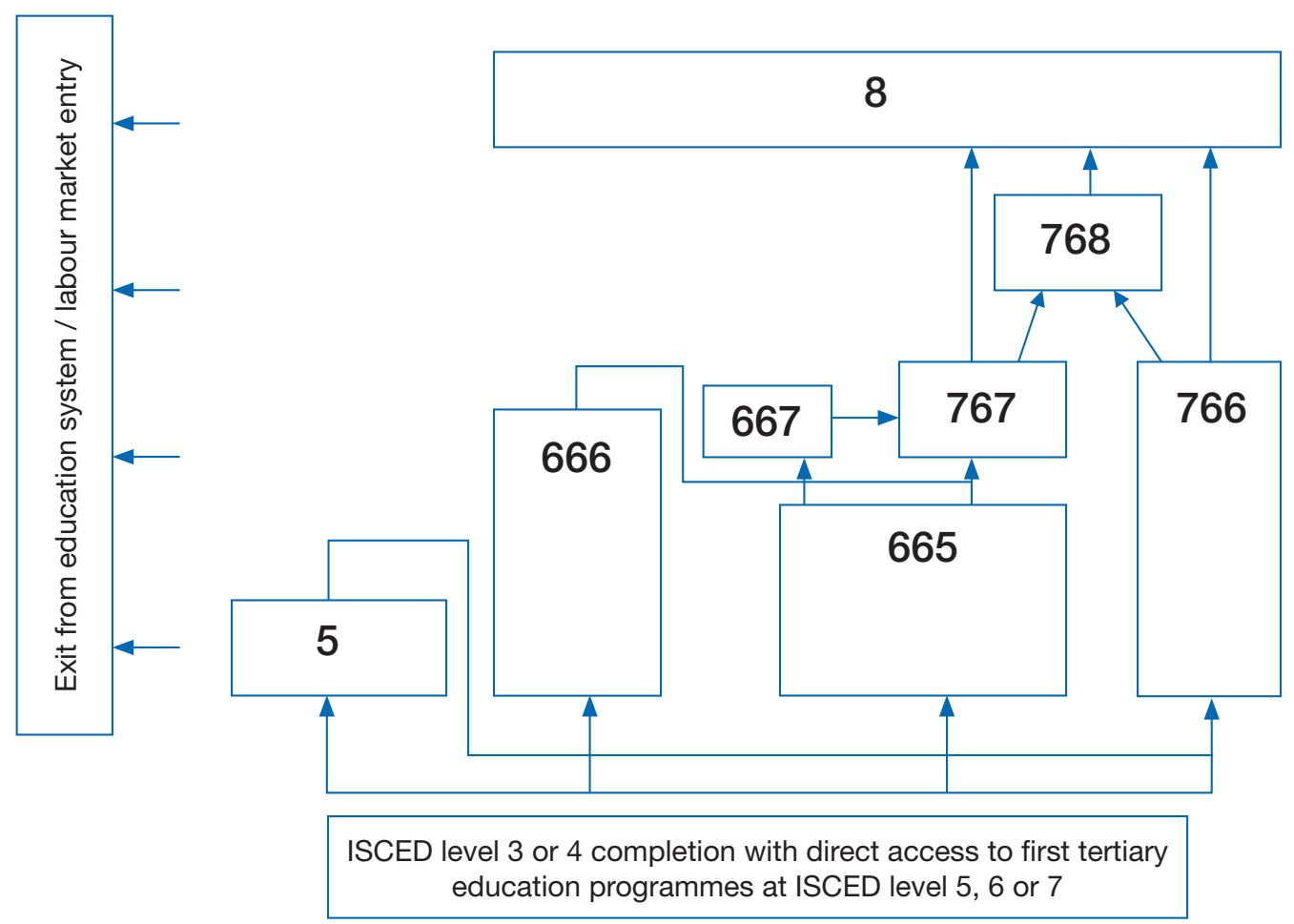

\section{CORRESPONDENCE BETWEEN ISCED 2011 AND ISCED 1997}

(§281) ISCED 2011 has four levels of tertiary education compared to two levels in ISCED 1997. Levels 5, 6 and 7 in ISCED 2011 together correspond to level 5 in ISCED 1997. Level 8 in ISCED 2011 corresponds to level 6 in ISCED 1997.

The new levels better identify the current structure of tertiary programmes, notably distinguishing Bachelor's programmes from Master's programmes.

(§282) ISCED 2011 simplifies the complementary dimensions at the tertiary ISCED levels compared to 1997.

- At level 5 in ISCED 2011, vocational programmes are differentiated from general programmes at the second digit. In ISCED 1997, this differentiation did not exist. It will also be possible to distinguish between academic and professional orientations within ISCED 2011 levels 6 to 8 once internationally-agreed definitions have been developed.

- At levels 6 and 7 of ISCED 2011, the third digit of the classification distinguishes programmes according to duration and position in the national degree and qualifications structure. The data reported by these sub-categories can be used for the calculation of statistics and indicators such as entry and graduation rates in tertiary education. In ISCED 1997, "type of programme" was used to sub-classify ISCED 5A into first degree programmes and second and further degree programmes (now corresponding to ISCED 2011 levels 6 and 7 combined).

\section{Note}

1. Paragraph numbers are references to the main ISCED 2011 classification document. See more details in the Reader's Guide. 



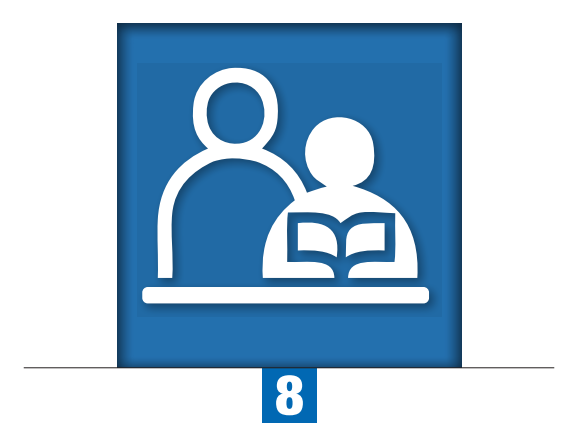

\section{Chapter 8}

\section{ISCED 2011 level 5:}

\section{Short-cycle tertiary education}

The content of ISCED level 5 programmes is noticeably more complex than in upper secondary programme(s) giving access to this level. ISCED level 5 programmes serve to deepen knowledge by imparting new techniques, concepts and ideas not generally covered in upper secondary education (whereas ISCED level 4 programmes serve to broaden knowledge and are typically not significantly more advanced than programmes at ISCED level 3).

Programmes classified at ISCED level 5 may be referred to in many ways, for example: higher technical education, community college education, technician or advanced/higher vocational training, associate degree, bac+2. For international comparability purposes, the term 'short-cycle tertiary education' is used to label ISCED level 5. 


\section{DESCRIPTION}

\section{Definition}

$(\S 207)^{1}$ Programmes at ISCED level 5 - short-cycle tertiary education-are usually practically-based, occupationallyspecific and prepare students to enter the labour market. However, they may also provide a pathway to other tertiary education programmes (ISCED levels 6 or 7). Some academic tertiary education programmes below the level of a Bachelor's programme or equivalent may also be classified as ISCED level 5.

(§208) Programmes at ISCED level 5 have more complex content than programmes at ISCED levels 3 and 4, but they are shorter and usually less theoretically-oriented than ISCED level 6 programmes.

\section{Classification criteria (\$211)}

\section{Main criteria}

a) Content

(§212) ISCED level 5 captures the lowest level of tertiary education. The content of programmes at this level is more complex than in secondary (ISCED level 3) or post-secondary non-tertiary education (ISCED level 4), but less complex than in ISCED level 6 (Bachelor's or equivalent level) programmes.

b) Entry requirements

(§208) Entry into ISCED level 5 programmes requires the successful completion of ISCED level 3 or 4 programmes that give access to tertiary education.

c) Minimum duration of level

(§213) ISCED level 5 has a minimum duration of 2 years.

\section{Subsidiary criteria}

a) Institutional transition point

(§214) The transition point from non-tertiary to tertiary educational institutions can help to identify the boundary between ISCED level 3, ISCED level 4 and tertiary education. ISCED level 5 programmes are often provided by different educational institutions than ISCED level 6, 7 and 8 programmes.

b) Typical duration of level

(§213) ISCED level 5 is typically but not always shorter than three years.

\section{Complementary dimensions}

(§216) Two dimensions may differentiate programmes at ISCED level 5.

(§217) Programme orientation:

- General; and

- Vocational ${ }^{2}$.

(§218) Level completion:

- No completion of ISCED level 5: programme of less than 2 years' duration (insufficient for level completion); and

- Completion of ISCED level 5: programme with duration of 2 or more years (sufficient for level completion). 


\section{CORRESPONDENCE BETWEEN ISCED 2011 AND ISCED 1997}

See correspondence section in the tertiary education chapter.

\section{GUIDELINES FOR CLASSIFYING PROGRAMMES AND THEIR RELATED RECOGNISED QUALIFICATIONS AT ISCED LEVEL 5}

The content of ISCED level 5 programmes is noticeably more complex than the upper secondary programme(s) giving access to this level. ISCED level 5 programmes serve to deepen knowledge by imparting new techniques, concepts and ideas not generally covered in upper secondary education (whereas ISCED level 4 programmes serve to broaden knowledge and are typically not significantly more advanced than programmes at ISCED level 3 (§191)). (Examples Group 1)

Programmes which require the successful completion of a programme at ISCED level 6 or 7 should not be classified at ISCED level 5 regardless of their duration.

Programmes of less than two years' duration immediately following upper secondary education should normally be classified at ISCED level 4 unless they are clearly directly equivalent to the first stage(s) of other programmes classified at ISCED level 5 (that meet the criteria for classification at ISCED level 5 including the minimum cumulative duration criterion of two years). (Examples Group 2)

In some cases, a sequence of short programmes may build to the equivalent of two to three years of study which meets the criteria for classification at ISCED level 5. Qualifications may exist at the end of each programme in the sequence. The first programme(s) in the sequence would therefore be classified at ISCED level 5 in ISCED-P ("insufficient for level completion", provided that the overall sequence is eligible for classification at level 5) and ISCED level 4 for educational attainment in ISCED-A (even if there is no corresponding ISCED level 4 programme at national level).

ISCED level 5 programmes may give credit for transfer into ISCED level 6 or 7 programmes (§209) meaning that participants are exempted from certain courses or modules of the ISCED level 6 or 7 programme to which they transfer because of their successful completion of the ISCED level 5 programme. (Examples Group 3)

The classification of very long programmes or of second programmes at the tertiary level need to be given careful consideration even if they were classified at ISCED 1997 level 5B. Second programmes representing at least five years' cumulative study at ISCED level 5 should normally be classified at ISCED level 6 (unless the resulting recognised qualification is clearly below the level of a Bachelor's degree). The resulting educational attainment would normally be at ISCED level 6 even if the duration of study in ISCED level 6 represents less than three years. This is because the total study at tertiary level is at least five years and hence the complexity of content mastered by the end of the programme should normally be equivalent to that covered in shorter first degree programmes at ISCED level 6.

Similarly, consideration should be given to treating very long first programmes (representing at least five years of study) which otherwise meet the criteria for classification at ISCED level 5 as programmes spanning ISCED levels 5 and 6. The first stage(s) of such programmes should be classified at ISCED level 5 and later stages as ISCED level 6 . As far as possible, the boundary between the two levels should be based on an assessment of the complexity of content of the different stages of the programme. As with second programmes, if the resulting qualification from the very long programme is clearly below the level of a Bachelor's degree, the whole programme should be classified at ISCED level 5 despite its long duration.

\section{EDUCATIONAL ATTAINMENT AT ISCED LEVEL 5}

Educational attainment at ISCED level 5 requires the successful completion - leading to a recognised qualification - of a programme representing a minimum cumulative duration at ISCED level 5 of at least two years. In the countries of the European Higher Education Area, this would be equivalent to at least 120 European Credit Transfer System credits.

The successful completion of programmes representing less than two years' study within ISCED level 5 normally gives rise to educational attainment at ISCED level 4 (even in countries which do not have any ISCED level 4 programmes).

\section{(Examples Group 4)}

Where programmes of different durations lead to qualifications that are recognised as equivalent to each other, they should normally be classified at the same ISCED level. ${ }^{3}$ Similarly, two or more different but equivalent qualifications should 
normally give rise to educational attainment at the same ISCED level though not necessarily to the same code (e.g. if one is general and the other is vocational the ISCED-A codes would be 540 and 550 respectively). In addition, when an education programme is shorter than two years in duration (e.g. where it is a part of a sequence of programmes) but the qualification obtained is equivalent to other qualifications classified at ISCED level 5, the programme and qualification should be classified at ISCED level 5. (Examples Group 5)

(\$221) For educational attainment, recognized intermediate qualifications from the successful completion of programme at ISCED level 5 which are insufficient for level completion are classified at ISCED level 4.

(\$222) Recognized intermediate qualifications from the successful completion of programmes (prior to the first degree) are not considered as sufficient for ISCED level 6 completion and are classified at ISCED level 5 for educational attainment.

The successful completion of first tertiary programmes representing less than three years' duration at ISCED level 6 gives rise to educational attainment at ISCED level 5 (even if there are no ISCED level 5 programmes in the given country). See Examples Group 4 in the ISCED level 6 chapter.

\section{EXAMPLES OF PROGRAMMES AND QUALIFICATIONS CLASSIFIED AT ISCED LEVEL 5}

(§210) Programmes classified at ISCED level 5 may be referred to in many ways: higher technical education, community college education, technician or advanced/higher vocational training, associate degree, bac +2 . For international comparability purposes, the term 'short-cycle tertiary education' is used to label ISCED level 5.

\section{Examples Group 1: \\ Programmes meeting all the criteria for classification at ISCED level 5 [ISCED-P: 544 or 554; ISCED-A: 540 or 550]}

Australia - Para-professional/Technician courses. These courses are designed to provide initial education and training to develop the breadth of specialised skills required for employment in para-professional vocations. Common awards are Associate Diploma or Advanced Certificate, and entry requirements usually specify that entrants hold a Certificate (ISCED 3) in the relevant field. Courses are generally of the order of two years' full-time equivalent duration. (ISCED-P: 554; ISCED-A: 550)

Brunei Darussalam - Higher National Diploma (HND). The is a 2.5-year vocational programme which requires the completion of an upper secondary education programme with access to tertiary education, such as the A-level, a National Diploma (ND) or the Sijil Tinggi Pelajaran Ugama (STPU) from religious schools. (ISCED-P: 554, ISCED-A 550)

Cambodia - Associate degree. This is a two-year programme which requires the completion of Grade 12 or a technical/ vocational certificate 3 (both ISCED level 3). The programme leads to associate degrees in tourism and hospitality, nursing and computer technology. (ISCED-P 554 / ISCED-A 550)

France - Enseignement conduisant aux Brevets de techniciens supérieurs et équivalent (Tertiary education leading to the Brevet de techniciens supérieurs (BTS) and equivalent). This is a two-year programme leading to the Brevet de technicien supérieur (BTS). The admission requirement is the baccalauréat or the brevet de technicien complemented by sufficient marks and recommendations from teachers. Holders of a BTS may, under certain conditions, continue their studies at university or in higher institutions. This qualification is at the same level as the diplôme universitaire de technologie (DUT - university diploma of technology), although it is more specialised and offers fewer opportunities for further studies. (ISCED-P: 554; ISCED-A: 550)

Japan - Koutou senmon gakko (Colleges of Technology, years 4-5). This is the last two years of the Koutou senmon gakko five-year programme of professional education. Students study mainly specialised engineering education. Upon successful completion of the programme and after passing an entrance examination, students can transfer into the 
third year of university programmes or advance to Koutou senmon gakko Senkoka (Advanced Engineering Course). (ISCED-P: 554; ISCED-A: 550).

Mauritania - Brevet de technicien supérieur (Senior technician certificate). This three-year programme requires the completion of the national Baccalauréat (upper secondary education). By the end of the programme, graduates receive the senior technician certificate. (ISCED-P: 554 and ISCED-A: 550)

Mexico - Técnico Superior (Technical professional education). These programmes are offered in Technological Institutes and lead to the Vocational Associate Certificate. Graduates from these two-year programmes are considered qualified technicians. (ISCED-P: 554; ISCED-A: 550)

Norway - Toårige fagskoleutdanning (Tertiary vocational education). These two-year vocational college programmes are designed to meet the requirements of master craftsmen, skilled technicians or para-professional vocations. They provide direct entry to the labour market. Graduates in technical studies, constituting the majority of graduates at this level, can get exemption for up to one year of a Bachelor's degree programme in engineering. The admission requirement is successful completion of upper secondary education or training (ISCED 3). (ISCED-P: 554; ISCED-A: 550)

Saudi Arabia - برامج الدبلوم المتوسط العام (Intermediate general diploma programmes). These programmes are offered in community colleges to upper secondary graduates in many fields of education. By the end of these two-year programmes, graduates are awarded the general intermediate diploma (لدبلوم العتوسط العام) in the respective field of education. (ISCED-P: 544; ISCED-A: 540)

Spain - Ciclos Formativos de Formación Profesional de Grado Superior (Vocational Training - Advanced Level). These programmes of two years' duration are included in the Spanish Higher Education Framework. The qualification obtained upon completion of this programme, Técnico Superior (Vocational training - advanced level Certificate and Title), is equivalent to that of a skilled technician in the given occupation. Admission is based on successful completion of the bachiller (ISCED level 3). (ISCED-P: 554; ISCED-A: 550)

Ukraine - Неповна вища освіта (Partial completion of higher education). These are two- to three-year programmes offered in higher education institutions. The minimum entry requirement is the completion certificate of upper secondary education. Upon completion of the programme, graduates receive the диплом молодиого спеціаліста (junior specialist diploma). (ISCED-P 554; ISCED-A 550)

\section{Examples Group 2: \\ Programmes of short duration but equivalent to the first stage(s) of another ISCED level 5 programme [ISCED-P: 541 or 551; ISCED-A: 444 or 454]}

United Kingdom - Higher National Certificate (HNC). To be admitted to this programme, participants must be at least 18 years old and have an appropriate national qualification awarded by the Business and Technical Education Council (BTEC) or equivalent or a GCE A-level (ISCED 3 qualifications). The aim of the programme is to develop skills and provide training that will lead to many vocational activities. It is provided by colleges, certain universities and some training centres. HNCs are shorter than the Higher National Diplomas (HND) lasting about one year full-time. Holders of HNCs can enter the second year of HND programmes and holders of some HNCs can enter the second year of a Bachelor's degree programme. This programme is classified at ISCED level 5. The educational attainment associated with the resulting qualification is completion of ISCED level 4 (as the programme duration is too short - one year - for completion of ISCED level 5.) (ISCED-P: 551; ISCED-A: 454)

\section{Examples Group 3:}

Programmes classified at ISCED level 5 giving credit towards further studies at ISCED levels 6 or 7 [ISCED-P: 544 or 554; ISCED-A: 540 or 550]

France - Enseignement en institut universitaire de technologie (IUT) (Education in a University Institute of Technology). A two-year programme in technology leading to the Diplôme universitaire de technologie (DUT). Holders of a DUT may continue studies at the university level to earn the licence (an ISCED level 6 qualification), although the programme is primarily designed to prepare students for direct labour market entry. The entry requirement is the baccalauréat, complemented by sufficient marks and recommendations from teachers. (ISCED-P: 554; ISCED-A: 550) 
Japan - Senmon gakko (Professional Training College). This programme mainly provides professional training. The minimum entry requirement is the successful completion of upper secondary education (ISCED level 3). Following completion of the programme, and upon meeting other specific requirements, a student can acquire a Diploma (duration of at least two years) or an Advanced Diploma (duration of at least four years). In general, the student would simultaneously be given the qualifications to enter university (ISCED level 6 or 766) or graduate school (ISCED level 7). (ISCED-P: 554; ISCED-A: 550)

Lebanon - برامج الامتباز الفني (Technical Excellence programmes). These are two-year programmes that are offered in technical and vocational institutes to the holders of either the vocational or general baccalaureate (upper secondary education). By the end of the programmes, graduates receive the technical excellence certificate Technique Supérieur (T.S.), which is designed to prepare skilled technicians for the labour market. This qualification is also considered as the entry requirement to the Technical License programme (الإجازة الفنبة العالبة), which is classified at the level of the Bachelor's (ISCED level 6). (ISCED-P: 554; ISCED-A: 550)

Sudan - بر امج الدبلوم الثقنية (Technical diploma programmes). These are three-year programmes offered by different national universities in various fields of education. Upon completion, participants are awarded the technical diploma certificate (شعادة دبلوم تثنى). Although this certificate is mainly designed for the labour market, along with relevant work experience, it can provide credits towards further studies at the Bachelor's level (ISCED level 6). (ISCED-P: 554; ISCED-A: 550)

Timor-Leste - Politecnic Diploma 2 (Professional programmes, Polytechnic Diploma 2). These are two-year vocational programmes which require the completion of upper secondary education (with access to tertiary education). Upon completion of these programmes, graduates receive the Diploma 2, which also provides credits for further education programmes, some of which are at the Bachelor's level. (ISCED-P: 554, ISCED-A: 550)

United Kingdom - Higher National Diploma (HND). To be admitted to this programme, participants must be at least 18 years old and have an appropriate national qualification awarded by the Business and Technical Education Council (BTEC) or equivalent or a GCE A-level (ISCED 3 qualifications). The aim is to develop skills and provide training that will lead to many vocational activities. It is provided by colleges, certain universities and some training centres and generally leads to the level of senior technician or junior management. The duration is either two years full time or three years part time. Holders of some HNDs can enter the second or third year of a Bachelor's degree programme. (ISCED-P: 554; ISCED-A: 550)

\section{Examples Group 4: \\ Programmes at ISCED level 5 insufficient for level completion therefore leading to educational attainment at ISCED level 4 [ISCED-P: 541 or 551; ISCED-A: 444 or 454]}

Denmark - Merkonom, teknonom, datanom, revision (Short-cycle higher education, open adult education). The entry requirement for this vocational programme is an upper secondary education (ISCED level 3) giving access to tertiary education. The programme is of one year's duration and the content is similar to the first year of two-year short-cycle tertiary education programmes classified as ISCED 5 in the country. As it is shorter than these programmes, it gives rise to educational attainment at ISCED level 4. (ISCED-P: 551; ISCED-A: 454)

United Kingdom - Higher National Certificate (HNC). This programme is classified at ISCED level 5 (insufficient for level completion) for the reasons described in Examples Group 2 above. The educational attainment associated with the resulting qualification is completion of ISCED level 4. (ISCED-P: 551; ISCED-A: 454)

\section{Examples Group 5:}

Programmes of less than two years' duration leading to attainment at ISCED level 5 [ISCED-P: 544 or 554; ISCED-A: 540 or 550]

Slovak Republic ${ }^{4}$ - Tančné konzervatórium - 8 ročné štúdium (Dance conservatory - eight years). This is an eight-year programme starting at age 10 to train professional dancers and provide them both with the school-leaving certificate (maturita, an ISCED 3 level qualification) - vysvedčenie o maturitnej skúške - and a graduate diploma - absolventský diplom - which is an ISCED level 5 qualification allowing holders to teach dance in the basic school of arts. The programme spans ISCED levels 2, 3 and 5 with Grades 1 to 4 classified at ISCED level 2, Grades 5 to 7 at ISCED level 3 and Grade 8 
at ISCED level 5. The qualification absolventský diplom is also awarded at the end of two other programmes meeting all the criteria for ISCED level 5: pomaturitné špecializačné štúdium (post-secondary specialised study) and vyššie odborné štúdium (higher professional studies) respectively two- and three-year programmes following successful completion of upper secondary education. Successful completion of the 8th grade of tanečné konzervatórium leads to educational attainment at ISCED level 5. Although only one year of the programme is classified at ISCED level 5, it leads to the same qualification as awarded at the end of other ISCED level 5 programmes. (ISCED-P: 554; ISCED-A: 550)

\section{Notes}

1. Paragraph numbers are references to the main ISCED 2011 classification document. See more details in the Reader's Guide.

2. If international definitions for: "academic" and "professional" programmes are developed, they will be used for the orientation categories at ISCED level 5 instead of "general" and "vocational".

3. Note that qualifications with the same name are not necessarily equivalent to each other especially where they can be taken in very different fields of study or where the qualification name is very generic (e.g. certificate, diploma, etc.).

4. The UNESCO Institute of Statistics (UIS) and the European Union (EU) use "Slovakia" as the official name of "Slovak Republic". 



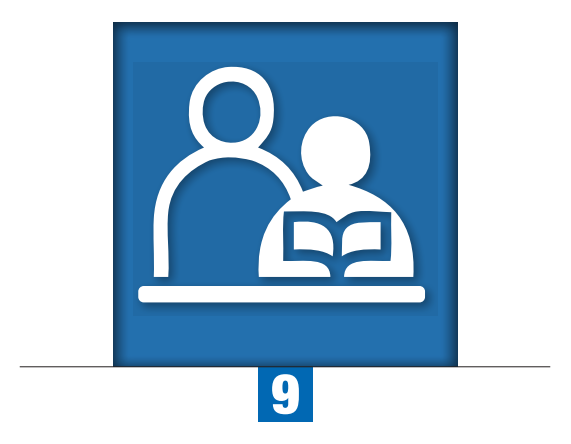

\section{Chapter 9}

\section{ISCED 2011 level 6:}

\section{Bachelor's or equivalent level}

Programmes at ISCED level 6, or Bachelor's or equivalent level, are longer and usually more theoretically-oriented than ISCED level 5 programmes. They are often designed to provide participants with intermediate academic and/or professional knowledge, skills and competencies, leading to a first degree or equivalent qualification.

They typically have a duration of three to four years of full-time study at the tertiary level. They may include practical components and/or involve periods of work experience as well as theoretically-based studies. They are traditionally offered by universities and equivalent tertiary educational institutions.

Programmes classified at ISCED level 6 may be referred to in many ways, for example: Bachelor's programme, licence or first university cycle. For international comparability purposes, the term 'Bachelor's or equivalent level' is used to label ISCED level 6. 


\section{DESCRIPTION}

\section{Definition}

$(\S 224)^{1}$ First programmes at ISCED level 6, or Bachelor's or equivalent level, are longer and usually more theoretically-oriented than ISCED level 5 programmes. They are often designed to provide participants with intermediate academic and/or professional knowledge, skills and competencies, leading to a first degree or equivalent qualification. Programmes at this level are typically theoretically-based but may include practical components and are informed by state of the art research and/or best professional practice. Programmes at ISCED level 6 do not necessarily require the preparation of a substantive thesis or dissertation.

(§226) Upon completion of ISCED level 6 programmes, individuals may continue their education at ISCED level 7 (Master's or equivalent level), although not all ISCED level 6 programmes provide access to ISCED level 7. ISCED level 6 programmes do not usually give direct access to programmes at ISCED level 8 (doctoral or equivalent level).

\section{Classification criteria (\$228)}

\section{Main criteria}

a) Theoretically- and/or professionally-based content

(§224) Programmes at this level are typically theoretically-based but may include practical components and are informed by state of the art research and/or best professional practice.

b) Entry requirements

(§226) Entry into these programmes normally requires the successful completion of an ISCED level 3 or 4 programme with access to tertiary education.

c) Minimum cumulative duration of (first-degree) programme

(§229) First-degree programmes at this level typically have a minimum cumulative duration of three years of fulltime study at the tertiary level. For systems in which degrees are awarded by credit accumulation, a comparable amount of time and intensity would be required.

d) Position in the national degree and qualification structure

(§230) Programmes at this level typically lead to first degrees. Programmes leading to a second or further degree may be included in ISCED level 6 if they are equivalent in complexity of content to programmes already classified at this level in the same education system and fulfil the other main criteria.

\section{Subsidiary criteria}

a) Staff qualifications

(§225) Instruction at this level often takes the form of lectures by staff who are typically required to have attained ISCED levels 7 or 8 or have achieved experience as a senior professional in the field of work. (\$231) Where appropriate, the requirement of ISCED level 8 qualifications for some of the teaching staff may be a good proxy criterion for education programmes at this level in education systems where such a requirement exists. This can serve to distinguish ISCED level 5 programmes from ISCED level 6 programmes. 
b) No direct access to ISCED level 8 programmes

(§225) Programmes at this level do not necessarily involve the completion of a research project or thesis, but if they do, it is less advanced, less independent or is undertaken with more guidance than those at ISCED level 7 or 8. (\$226) ISCED level 6 programmes do not usually give direct access to programmes at ISCED level 8 (doctoral or equivalent level).

\section{Complementary dimensions}

(§233) Two dimensions may differentiate programmes at ISCED level 6.

(§234) Programme orientation:

- Academic; and

- Professional ${ }^{2}$.

(§235) Programme duration and position in the national degree and qualification structure:

- Stage (or programme) within a first tertiary degree at Bachelor's or equivalent leve/ with a cumulative theoretical duration (at tertiary level) of less than three years, therefore insufficient for completion of ISCED level 6;

- First tertiary degree programme with a cumulative theoretical duration (at tertiary level) of three to four years, at ISCED level 6 (Bachelor's or equivalent level);

- Long first degree programme with a cumulative theoretical duration (at tertiary level) of more than four years, at ISCED level 6 (Bachelor's or equivalent level); and

- Second or further degree programme, following successful completion of a Bachelor's or equivalent programme, at ISCED level 6 (Bachelor's or equivalent level).

\section{CORRESPONDENCE BETWEEN ISCED 2011 AND ISCED 1997}

See correspondence section in the tertiary education chapter.

\section{GUIDELINES FOR CLASSIFYING PROGRAMMES AND THEIR RELATED RECOGNISED QUALIFICATIONS AT ISCED LEVEL 6}

Programmes at ISCED level 6, or Bachelor's or equivalent level, are longer and usually more theoretically-oriented than ISCED level 5 programmes. They are often designed to provide participants with intermediate academic and/or professional knowledge, skills and competencies, leading to a first degree or equivalent qualification (§224).

They may include practical components and/or involve periods of work experience as well as theoretically-based studies (§230).

They are traditionally offered by universities and equivalent tertiary educational institutions (§224).

It is important to note that programmes with a similar name to "Bachelor" should only be included in ISCED level 6 if they are equivalent in complexity of content and fulfil the other main criteria (\$227).

Entry into first programmes at Bachelor's or equivalent level normally requires the successful completion of an ISCED level 3 or 4 programme with access to tertiary education. Entry may depend on subject choice and/or grades achieved at ISCED levels 3 and/or 4. It may also be necessary to take and succeed in entrance examinations. Entry or transfer into ISCED level 6 is also sometimes possible after the successful completion of ISCED level 5 (§226) (see Examples Group 4 at ISCED level 5).

Programmes at this level typically lead to first degrees and equivalent qualifications in tertiary education (although individuals may have completed an ISCED level 5 qualification prior to enrolling in an ISCED level 6 programme) (§230). They typically have a duration of three to four years of full-time study at the tertiary level. For systems in which degrees are awarded by credit accumulation, a comparable amount of time and intensity would be required (§229). (Examples

\section{Group 1)}


Long first degrees of more than four years' duration are included at this level if equivalent to Bachelor's programmes in terms of complexity of content (§230). Examples Group 2. However, long first degrees in highly-specialised professional studies (e.g. medicine, dentistry, veterinary studies and, in some cases, law or engineering) are usually classified at ISCED level 7 (\$247). They are typically substantially longer than other first degrees classified at ISCED level 6 and cover - both in depth and in breadth - more complex content of a type more similar to Master's or equivalent level.

Programmes which require a Bachelor's degree to enter should be classified as second or further degrees (even if they do not lead to a degree). Such programmes at this level are typically of one to two years' duration, often professionallyoriented and offering more specialisation than the first degree but do not include substantially more complex content (§230). Examples Group 3. Programmes following a Bachelor's which have a substantial research component should normally be classified at ISCED level 7.

Upon completion of ISCED level 6 programmes, individuals may continue their education at ISCED level 7 (Master's or equivalent level), although not all ISCED level 6 programmes provide access to ISCED level 7 (\$226). Programmes which require the successful completion of a programme at ISCED level 7 for entry should not be classified at ISCED level 6 regardless of their duration.

\section{EDUCATIONAL ATTAINMENT AT ISCED LEVEL 6}

Educational attainment at ISCED level 6 requires the successful completion - leading to a recognised qualification - of a programme representing a minimum duration at ISCED level 6 of at least three years. In the countries of the European Higher Education Area, this would be equivalent to at least 180 European Credit Transfer System credits.

(\$238) For educational attainment, recognised intermediate qualifications from the successful completion of stages of programmes (prior to the first degree) which are insufficient for ISCED level 6 completion are classified at ISCED level 5.

The successful completion of programmes representing less than three years' study within ISCED level 6 normally gives rise to educational attainment at ISCED level 5 (even in countries which do not have any ISCED level 5 programmes).

Examples Group 4.

(\$239) Recognised intermediate qualifications from the successful completion of programmes (prior to the first degree) which are insufficient for ISCED level 7 completion are classified at ISCED level 6 for educational attainment.

Honorary degrees awarded by universities on the basis of other considerations and not any research work are not recognised for the purposes of educational attainment.

\section{EXAMPLES OF PROGRAMMES AND QUALIFICATIONS CLASSIFIED AT ISCED LEVEL 6}

(\$227) Programmes classified at ISCED level 6 may be referred to in many ways, for example: Bachelor's programme, licence, or first university cycle. However it is important to note that programmes with a similar name to 'Bachelor' should only be included in ISCED level 6 if they satisfy the criteria described in [ISCED 2011] Paragraph 228. For international comparability purposes, the term 'Bachelor's or equivalent level' is used to label ISCED level 6.

\section{Examples Group 1: \\ First degree programmes at Bachelor's or equivalent level (three to four years) [ISCED-P: 645, 655 or 665; ISCED-A: 640,650 or 660]}

Djibouti - Enseignement supérieur de cycle long (Long cycle tertiary education). This is a four-year tertiary programme that requires the completion of upper secondary education with access to tertiary education as the minimum condition for admission. After completion, graduates receive a Bachelor's equivalent degree (Licence or Maitrise) in the relevant field of study. (ISCED -P: 665; ISCED-A: 660) 
Finland - Ammattikorkeakoulututkinnot (Polytechnic Bachelor's degree programme). These programmes (three to four years in duration) prepare for occupations with high skill requirements. They combine theoretical studies (basic and professional studies) with work and practical training. The programmes involve completion of a large research project or thesis. Students must have completed upper secondary education prior to entry. (ISCED-P: 665; ISCED-A: 660)

Germany - Fachhochschulen (Universities of Applied Sciences). This is a four-year programme at the university level that prepares for occupations which require the application of scientific findings and methods. Students must at least have completed Fachoberschule (ISCED 3 or 4) or equivalent. It leads to a first tertiary degree, Diplom (FH). (ISCED-P: 645; ISCED-A: 640)

Japan - Koutou senmon gakko Senkoka, Tokurei Tekiyou Senkoka (College of Technology, NIAD-UE validated advanced course). This programme follows the successful completion of the five-year Koutou senmon gakko (Colleges of Technology) programme (first three years: ISCED-P 354, last two years: ISCED-P 554). Although by law these programmes must have a minimum duration of at least one year, all Koutou senmon gakko Senkoka programmes extend over two years, and provide an advanced-specialised engineering education. Students who successfully complete Tokurei Tekiyou Senkoka (College of Technology, NIAD-UE validated advanced course), which is recognised as equivalent to an undergraduate programme by the National Institution for Academic Degrees and University Evaluation (NIAD-UE), may be awarded a Bachelor's degree and may progress to graduate school. (ISCED-P: 665; ISCED-A: 660)

Kyrgyzstan - Высшее профессиональное образование, ведущее к поступлению в программы продвинутых научных исследований и получению диплома бакалавра (Bachelor's degree education programme). This is a four-year tertiary programme which requires the certificate of upper secondary education to enter. After successful completion, graduates are awarded a Bachelor's degree in the relevant field of education. (ISCED-P: 665; ISCED-A: 660)

Netherlands - Hoger beroepsonderwijs (HBO) (Professional Bachelor's degree programmes). HBO programmes provide theoretical and practical training for occupations for which a higher vocational qualification is required. In these four-year higher professional education programmes, teaching is of a more practical nature than in universities. The most common fields studied are agriculture, teacher education, social work and community education, health care and the arts. (ISCED-P: 655; ISCED-A: 650)

Spain - Diplomatura Universitaria (University education - first degree (first cycle)). This is a first three-year university degree programme leading to the Diplomado Universitario, Arquitecto Técnico or Ingeniero Técnico in a particular field. Holders of these qualifications may enter the labour market directly or be admitted to second-cycle university education. (ISCED-P: 665; ISCED-A: 660)

Switzerland - Fachhochschule, haute école spécialisée (Bachelor's degree programme). These three- to four-year programmes require a "Berufsmaturität/maturité professionnelle" (ISCED 3 vocational education of three or four years' duration with a substantially enlarged general education component) for entry. They prepare students for highly-skilled professions in fields of study such as architecture, engineering, business administration, design, health, social work, arts and education. (ISCED-P: 645; ISCED-A: 640)

Thailand - Vocational Education and Training programmes at Bachelor's level (continuing education). These two-year programmes are offered within the context of continuing education. Admission to these programmes requires the completion of a two-year vocational diploma that is classified as short-cycle tertiary education (ISCED level 5). The programme therefore represents a total cumulative duration of four years' study at tertiary level. Upon successful completion, graduates are awarded a Bachelor's equivalent degree. (ISCED-P 665; ISCED-A 660)

Tunisia - الإجازة التطبيقية (Applied degree). This is a three-year first university degree programme which requires the completion of upper secondary education with access to tertiary education as the minimum condition for admission. Upon completion, graduates receive the applied degree (Licence appliquée) in a particular field of education leading to the labour market and to a higher level of education. (ISCED-P: 665, ISCED-A: 660)

United Kingdom - Honours degree - Bachelor's degree programme. This is a first tertiary degree, awarded usually after three years of study. Students usually have to satisfy examiners in a series of annual examinations or by a system of continuous assessment, as well as sit for a final degree examination at the end of the programme. The honours degree usually comprises the study of one main and one subsidiary subject only. (ISCED-P: 665; ISCED-A: 660) 
United States - Bachelor's degree programme. This is typically a four-year programme undertaken at colleges or universities. These undergraduate programmes typically require a high school diploma or equivalent for entry. Bachelor's degree recipients can enter the labour force or continue their education in graduate (Master's or PhD) or first professional (law, medicine, dentistry) degree programmes. (ISCED-P: 665; ISCED-A: 660)

\section{Examples Group 2: \\ Long first degree programmes at Bachelor's or equivalent level (more than four years) [ISCED-P: 646, 656 or 666; ISCED-A: 640, 650 or 660]}

Algeria - مهندس دولة (State engineer). This is five-year tertiary programme that is offered to graduates from upper secondary education. Upon completion, graduates from this programme receive a state engineer degree (Ingénieur d'état) in different fields of education. (ISCED-P: 666, ISCED-A: 660)

Colombia - Título Universitario (University degree). These programmes are long first university degrees (at least four years in duration, usually five), which provide the student with a professional title or a title in a specific subject. Admission to the programme requires the completion of upper secondary education (ISCED level 3), as well as success in the State examination for entry into tertiary education. (ISCED-P: 666, ISCED-A: 660)

Denmark - Mellemlange videregående uddannelser - professionsbachelor (Tertiary education, medium cycle, professional Bachelor's). These five-year programmes are entered following successful completion of upper secondary education (ISCED level 3). They prepare students for professional work in certain fields such as engineering. The degree obtained is considered similar to the level of other Bachelor's degrees, which are three to four years long. Upon completion, students may enter the given profession and may also have the possibility to enter a Master's programme. (ISCED-P: 656, ISCED-A: 650)

Mexico - Licenciatura universitaria (University Bachelor's, five years). The entry requirement for these university programmes is the Bachillerato (upper secondary certificate). While the duration of other Licenciatura programmes in the country are one year less, the five-year degrees obtained are considered to be similar and are all at the level of ISCED 6. Upon completion of these programmes, students may enter a Maestría (Master's level programme, ISCED 7). (ISCED-P: 646, ISCED-A: 640)

Syrian Arab Republic - بر/مج العندسة التقنتيّة (Technical engineering programmes). These are five-year tertiary education programmes in the fields of engineering that require the completion of upper secondary as a minimum condition for admission. After successful completion, graduates are awarded a Bachelor's degree in engineering. (ISCED-A: 666; ISCED-A: 660)

\section{Examples Group 3: \\ Second or further degree (following successful completion of a Bachelor's or equivalent programme) [ISCED-P: 647, 657 or 667; ISCED-A: 640,650 or 660]}

Côte d'Ivoire - Enseignement universitaire général : $2^{e}$ cycle (Maîtrise) (General university education, second cycle leading to the Maitrise). This is a second degree programme following successful completion of a License, a Bachelor's equivalent programme. The programme lasts for only one year and has no substantive research component. (ISCED-P: 667, ISCED-A: 660).

India - Bachelor of Education (B.Ed). This is a one-year tertiary programme in education which is offered to holders of a Bachelor's degree from different disciplines who are interested in pursuing a career in teaching. A Bachelor of Education degree is awarded at the end of the programme. (ISCED-P: 667, ISCED-A: 660)

Ireland - Higher Diploma. This diploma is normally awarded following completion of a programme of one year's duration in a recognised higher education institution. The entry requirement for a Higher Diploma programme is typically an Honours Bachelor's degree, but Ordinary Bachelor's degrees can also provide access. Successful completers of the Higher Diploma may progress to a Post-graduate Diploma, Master's degree or, in some cases, programmes leading to a doctoral degree. (ISCED-P: 667; ISCED-A: 660)

Morocco - برامج تكوبن أساتذة التعليم الابتدائي (Primary education teacher training programme). This is a one-year programme that requires the completion of a Bachelor's equivalent programme (Diplôme de Licence d'études fondamentales (LEF)) 
for entry. Following the completion of the teacher training programme, students are awarded the Certificat d'études normales d'instituteurs (CENI), which enables holders to practise as qualified teachers in primary education. (ISCED-P: 667 and ISCED-A: 660)

Norway - Videreutdanning (Specialisation courses). These programmes include a variety of vocationally-oriented specialisations, particularly for paramedical professions and teachers, the longest being in midwifery (two years after qualification as a nurse). They build on a Bachelor's degree but do not lead to a Master's degree. (ISCED-P: 647; ISCED-A: 640)

Saudi Arabia - برامج الدبلوم العالي (Higher diploma programmes). These are one- to two-year tertiary programmes which require the completion of a Bachelor's degree (درجة البكالوريوس) as the minimum entry requirement. Mostly offered in the field of education, these programmes lead to a higher diploma (دبلوم عالي) that is considered nationally below the level of a Master's degree. (ISCED-P: 667 and ISCED-A: 660)

Switzerland - Fachhochschule Nachdiplom, haute école spécialisée diplôme postgrade (Master of Advanced Studies). After the first degree, universities offer Master's degree programmes or specialisation programmes not leading to a research degree (Master of Advanced Studies). They typically last one year or 60 ECTS credits. Examples include business administration for engineers or specialisation in environmental aspects for chemical engineers. The cumulative duration at ISCED level 6 ranges from 4-6.5 years, depending on the specific programme. The resulting qualification is considered to be at a level similar to the first Bachelor's degree. (ISCED-P: 647; ISCED-A: 640)

\section{Examples Group 4:}

Programmes at ISCED level 6 insufficient for level completion therefore leading to educational attainment at ISCED level 5 [ISCED-P: 641, 651 or 661; ISCED-A: 540, 550 or 560]

Burkina Faso - Diplôme universitaire d'études générales (DEUG) (University diploma in general studies). This is a two-year tertiary programme that requires the completion of upper secondary education (ISCED level 3). Following the DEUG, students may proceed to a one-year License (Bachelor's) programme or a three-year engineering diploma. (ISCED-P: 661; ISCED-A: 540).

Burundi - 1er cycle de l'enseignement supérieur (First cycle of tertiary education). This is a two-year programme forming the first cycle of a Bachelor's degree programme (or Licence). The second cycle can either be two or three years long depending on the field of education. Following the successful completion of the first cycle, which requires the completion of upper secondary education with access to tertiary for entry, students can proceed to the second cycle. (ISCED-P: 661; ISCED-A: 540).

Canada - University Transfer Programmes. These are programmes of one or two years' duration offered by nonuniversity institutes under special arrangements with universities whereby the college offers the first year(s) of a university degree programme. Students who complete these programmes at the colleges can then transfer their credits toward university Bachelor's degree programmes. Although enrolment in these programmes count at ISCED level 6, students who complete these programmes are not reported as ISCED level 6 graduates. Their educational attainment is at ISCED level 5. (ISCED-P: 641; ISCED-A 540).

Norway - Høgskolekandidat (University college degree). The university college degree is a tertiary programme of two years. Students must have completed upper secondary education (ISCED level 3) prior to entry. This degree often becomes an integrated part of the full Bachelor's programme upon graduation. (ISCED-P: 641; ISCED-A: 540)

\section{Notes}

1. Paragraph numbers are references to the main ISCED 2011 classification document. See more details in the Reader's Guide.

2. Although there are as yet no internationally-agreed definitions of academic and professional orientations, some countries are applying their national definitions and making use of these codes in their ISCED mappings. 



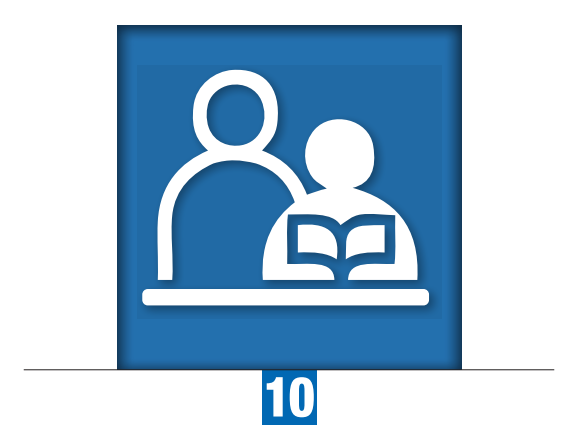

\section{Chapter 10}

\section{ISCED 2011 level 7:}

\section{Master's or equivalent level}

Programmes at ISCED level 7, or Master's or equivalent level, have a significantly more complex content than programmes at ISCED level 6 and are usually more specialised. The content of ISCED level 7 programmes is often designed to provide participants with advanced academic and/ or professional knowledge, skills and competencies, leading to a second degree or equivalent qualification. Programmes at this level may have a substantial research component but do not yet lead to the award of a doctoral qualification. The cumulative duration of studies at the tertiary level thus lasts from usually five to eight years or even longer.

Programmes classified at ISCED level 7 may be referred to in many ways, for example: Master programmes or Magister studies. For international comparability purposes, the term 'Master's or equivalent level' is used to label ISCED level 7. 


\section{DESCRIPTION}

\section{Definition}

$(\S 241)^{1}$ Programmes at ISCED level 7, or Master's or equivalent level, are often designed to provide participants with advanced academic and/or professional knowledge, skills and competencies, leading to a second degree or equivalent qualification. Programmes at this level may have a substantial research component but do not yet lead to the award of a doctoral qualification. Typically, programmes at this level are theoretically-based but may include practical components and are informed by state of the art research and/or best professional practice.

(§243) ISCED level 7 programmes have a significantly more complex content than programmes at ISCED level 6 and are usually more specialised. Upon completion, individuals may continue their education at ISCED level 8 (doctoral-level education) although not all ISCED level 7 programmes give direct access to ISCED level 8.

\section{Classification criteria (\$228)}

\section{Main criteria}

a) Theoretically- and/or professionally-based content

(\$241) Programmes at this level are typically theoretically-based but may include practical components and are informed by state of the art research and/or best professional practice.

b) Position in the national degree and qualification structure

(§246) Programmes at this level typically prepare for a second or further degree, following a first degree from ISCED level 6 or 7 programmes.

(\$247) Programmes of at least five years' duration preparing for a long first degree/qualification are included at this level if they are equivalent to Master's-level programmes in terms of their complexity of content. Highlyspecialised professional studies of similar or greater cumulative duration in tertiary education (e.g. medicine, dentistry, veterinary studies and, in some case, law or engineering) which cover - both in breadth and depth - an equivalent amount of content, are also included in this level.

a) Entry requirements

(§243) Entry into ISCED level 7 programmes preparing for a second or further degree normally requires the successful completion of an ISCED level 6 or 7 programme. In the case of long programmes that prepare for a first degree equivalent to a Master's degree, entry requires the successful completion of an ISCED level 3 or 4 programme with access to tertiary education.

\section{Subsidiary criteria}

b) Minimum cumulative duration of long first degree programme

(§247) Programmes of at least five years' duration preparing for a long first degree/qualification are included at this level.

c) Direct access to ISCED level 8 programmes

(§249) Tertiary education programmes providing direct access to ISCED level 8 are normally classified at ISCED level 7. However, not all ISCED level 7 programmes provide access to ISCED level 8. 


\section{Complementary dimensions}

(§251) Two dimensions may differentiate programmes at ISCED level 7.

(§252) Programme orientation:

- Academic; and

- Professional ${ }^{2}$.

(§253) Programme duration and position in the national degree and qualification structure

- Stage (or programme) within a first degree at Master's or equivalent level with a cumulative theoretical duration (at tertiary level) of less than five years, therefore insufficient for completion of ISCED level 7;

- Long first degree programme, with a cumulative theoretical duration (at tertiary level) of at least five years (that does not require prior tertiary education), at ISCED level 7 (Master's or equivalent level);

- Second or further degree programme, following successful completion of a Bachelor's or equivalent programme, at ISCED level 7 (Master's or equivalent level); and Second or further degree programme at Master's or equivalent level, following successful completion of another Master's or equivalent programme, at ISCED level 7 (Master's or equivalent level).

\section{CORRESPONDENCE BETWEEN ISCED 2011 AND ISCED 1997}

See correspondence section in the tertiary education chapter.

\section{GUIDELINES FOR CLASSIFYING PROGRAMMES AND THEIR RELATED RECOGNISED QUALIFICATIONS AT ISCED LEVEL 7}

ISCED level 7 programmes have a significantly more complex content than programmes at ISCED level 6 and are usually more specialised (\$243). The content of ISCED level 7 programmes is often designed to provide participants with advanced academic and/or professional knowledge, skills and competencies, leading to a second degree or equivalent qualification. Programmes at this level may have a substantial research component but do not yet lead to the award of a doctoral qualification (§241).

They are traditionally offered by universities and equivalent tertiary educational institutions (§224). Programmes with a similar name to 'Master's' should only be included in ISCED level 7 if they are equivalent in complexity of content to programmes already classified at this level and fulfil the other main criteria (§244).

Entry into ISCED level 7 programmes preparing for a second or further degree normally requires the successful completion of an ISCED level 6 or 7 programme. In the case of long programmes that prepare for a first degree equivalent to a Master's degree, entry requires the successful completion of an ISCED level 3 or 4 programme with access to tertiary education. Entry may depend on subject choice and/or grades achieved at ISCED levels 3 and/or 4 . It may also be necessary to take and succeed in entrance examinations (\$243).

Programmes at this level typically prepare for a second (Examples Group 1) or further degree, following a first degree from ISCED level 6 or 7 programmes (§248). Equivalent qualifications, such as post-graduate professional qualifications (Examples Group 1), are also classified at ISCED level 7 unless already classified at ISCED level 6 (\$246). Both types of programmes typically have a duration of one to four years of full-time study. In education systems in which degrees are awarded by credit accumulation, a comparable amount of time and intensity would be required. The cumulative duration of studies at the tertiary level thus lasts from usually five to eight years or even longer (§248).

Programmes of at least five years' duration preparing for a long first degree/qualification are included at this level if they are equivalent to Master's level programmes in terms of their complexity of content. Such programmes usually involve the preparation of a substantive thesis or dissertation (§247). (Examples Group 2)

Highly-specialised professional studies of similar or greater cumulative duration in tertiary education (e.g. medicine, dentistry, veterinary science and in some cases law or engineering) which cover - in both breadth and depth - an equivalent amount of content, though typically without the preparation of a thesis or dissertation, are also included at this level (§247). (Examples Group 3) 
Upon completion, individuals may continue their education at ISCED level 8 (doctoral-level education) although not all ISCED level 7 programmes give direct access to ISCED level 8 (§243).

\section{EDUCATIONAL ATTAINMENT AT ISCED LEVEL 7}

Educational attainment at ISCED level 7 requires the successful completion - leading to a recognised qualification - of a programme representing a minimum cumulative duration at tertiary level of at least five years. In the countries of the European Higher Education Area, this would be equivalent to at least 300 European Credit Transfer System credits.

(§256) For educational attainment, recognized intermediate qualifications from the successful completion of stages (or programmes) within a first degree at a Master's or equivalent level but insufficient for ISCED level 7 completion are classified at ISCED level 6.

The successful completion of programmes representing less than five years' study within tertiary level normally gives rise to educational attainment at ISCED level 6.( Examples Group 4)

(§257) Recognized intermediate qualifications from the successful completion of stages (or programmes) at the doctoral or equivalent level but insufficient for ISCED level 8 completion are classified at ISCED level 7 for educational attainment.

Honorary degrees awarded by universities on the basis of other considerations and not any research work are not recognised for the purposes of educational attainment.

\section{EXAMPLES OF PROGRAMMES AND QUALIFICATIONS CLASSIFIED AT ISCED LEVEL 7}

(§244) Programmes classified at ISCED level 7 may be referred to in many ways, for example: master programmes or magister. However it is important to note that programmes with a similar name to "master" should only be included in ISCED level 7 if they satisfy the criteria described in [ISCED 2011] Paragraph 245. For international comparability purposes the term "Master's or equivalent level" is used to label ISCED level 7.

\section{Examples Group 1: \\ Second or further degree programme at Master's or equivalent level (following successful completion of a Bachelor's or equivalent programme) [ISCED-P: 747, 757 or 767; ISCED-A: 740, 750 or 760]}

Australia - Master's degree. This is a higher degree, obtained typically after a period of two years' study following a Bachelor's degree (honours). Following a Bachelor's degree (pass), entry to a Master's degree may be possible by completing a Master's qualifying course of one year. Master's degrees may be obtained by research (usually entered after a period of employment) culminating in the submission of a thesis or by course work often undertaken in conjunction with professional employment. (ISCED-P: 767; ISCED-A: 760)

Colombia - Maestría (Master's degree). This programme leads to the title of Magister (Master's) and requires a professional title or a university degree in the fields of technology, science, humanities, arts or philosophy for entry. The programme duration is usually two years (ISCED-P: 767, ISCED-A: 760)

Japan - Daigakuin Shushi katei. (University graduate programme leading to the shushi (Master's degree)). Completion of the shushi degree requires two years' full-time study following the gakushi (Bachelor's degree), including 30 credits and a substantial amount of research culminating in a thesis. (ISCED-P: 767; ISCED-A: 760)

Mexico - Maestría (Master's degree programmes). This programme involves advanced research and the acquisition of comprehensive knowledge about specific subjects and fields of study. The duration of the programme is commonly two years. The entry requirement is a four- or five-year Licenciatura (Bachelor's degree) programme. (ISCED-P: 767; ISCED-A: 760) 
Sao Tome and Principe - Mestrado (Master's programme). This is a two-year classical post-graduate programme leading to a second degree following the successful completion of a Bachelor's equivalent programme (License). Completion of this programme, which is the highest within the national education system, leads to a Master's degree (Mestrado). (ISCED-P: 767, ISCED-A: 760)

Slovenia - Magistrsko izobraževanje (2. bolonjska stopnja) (Master's degree). The duration of these studies is of one to two years, after successful completion of ISCED level 6 (1 ${ }^{\text {st }}$ Bologna cycle). Graduates obtain a Master's diploma (with the professional title) which give access to doctorate studies. (ISCED-P: 767; ISCED-A: 760)

United States - First-professional degree programmes. Completion of these programmes signifies both completion of the academic requirements to begin practicing in a given profession and a level of professional skill beyond that normally required from a Bachelor's degree. These programmes typically last three years and require at least two years at ISCED level 6 prior to entrance (although most require a four-year Bachelor's degree). These first professional degrees are the normal route to qualify as a professional in the fields of dentistry, medicine, optometry, pharmacy, veterinary medicine, law and theological professions. (ISCED-P: 757; ISCED-A: 750)

\section{Examples Group 2: \\ Long first degree programme at Master's or equivalent level (at least five years) [ISCED-P: 746,756 or 766 ; ISCED-A: 740,750 or 760 ]}

Gambia - Medical degree. This is a seven-year programme after the completion of upper secondary education. At the end of the programme, learners are awarded a Master's degree in Medicine. (ISCED-P: 766, ISCED-A: 750)

Germany - Universitäten - Diplom, Magister. (University - Magister Diploma) These former university programmes have not been adapted to the Bologna structure. They led after 8 to 10 semesters to a first degree equivalent to a Master's degree (ISCED-P: 746; ISCED-A: 740). These programmes involved the preparation of a substantive thesis or dissertation in addition to coursework in the earlier semesters of the programme. Graduates of the programme could enter doctoral programmes. (ISCED-P: 746; ISCED-A: 740)

Germany - Universitäten - Staatsexamen (University programmes in the fields of teacher training, dentistry, medicine, veterinary medicine, pharmacy, law and theological professions). After 8 to 10 semesters of university studies, these programmes lead to a state examination equivalent to a Master's degree (ISCED level 7). (ISCED-P: 746; ISCED-A: 740)

Japan - Daigaku Yakugaku Ishigaku Juigaku (University undergraduate programme). The gakushi is the first qualification awarded after six years in pharmacy (practical course only) medicine, dentistry and veterinary studies. In addition to study in one of these specialised fields, general education (which includes humanities, social and natural sciences) is obligatory for every student. (ISCED-P: 766; ISCED-A: 760)

Kyrgyzstan - Высшее профессиональное образование, ведущее к поступлению в программы продвинутых научных исследований и получению диплома спеиииалиста (Long first tertiary degree programme, leading to a specialist diploma). This first university degree has a duration of five years. The minimum entry requirement is the certificate of upper secondary education. The programme includes courses with significantly more complex content than other common programmes at ISCED 6. At the end of the programme, graduates receive a specialist diploma. (ISCED-P: 766, ISCED-A: 760)

Lao People's Democratic Republic - Licence de médecine (Bachelor's degree in medicine). This is a long first tertiary degree programme (six years in duration) that requires the completion of upper secondary education with access to tertiary education (Certificat de Baccalauréat) for entry. This is a highly-specialised programme of very long duration. Although the title of the degree received is a Bachelor's in medicine, it involves substantially more complex studies than a regular Bachelor's and therefore is considered to be at the level of a Master's. (ISCED-P 766; ISCED-A 760)

Mozambique - Mestrado Integrado (Integrated Master's). This is five-year first degree programme which requires the completion of upper secondary education as the minimum entry requirement. By the end of the programme, graduates are awarded a Master's degree. (ISCED-P: 766, ISCED-A: 760)

Portugal - Ensino Superior - Licenciatura (Tertiary education - long first degree, four to six years). These are pre-Bologna programmes. These four- to six-year programmes, usually offered by universities, were entered following successful completion of secondary education. In most fields of education, the programmes lasted four to five years. In certain fields 
of study there were also six-year programmes. Students with a graduation mark of 16 or higher could access directly the doctoral level. The final qualifications obtained from these pre-Bologna programmes are nationally recognised as equivalent to ISCED 7 in ISCED 2011. (ISCED-P: 766; ISCED-A: 760)

\section{Examples Group 3: \\ Second or further degree programme at Master's or equivalent level (following a Master's or equivalent programme) [ISCED-P: 748, 758, 768; ISCED-A: 740,750,760]}

Australia - Doctor of Philosophy by coursework. These three-year programmes may be entered following successful completion of a first Master's degree. They offer more specialisation in professional and academic fields of study. The programme is course-based and does not lead to a doctoral-level thesis of original research representing a significant contribution to knowledge within the field of study. Therefore the degree obtained is still considered similar to the Master's level (ISCED level 7). (ISCED-P: 748; ISCED-A: 740)

Canada - Graduate qualifying programme (third cycle). Entry into these one- to two-year programmes requires the successful completion of a first Master's degree. These programmes prepare students to pursue studies at the doctoral level if their previous education did not meet all the necessary requirements (for example, students who initially studied in one field and wish to pursue further studies at the doctoral level in a different or more specialised area; or whose first Master's degree was more professional than academic). The qualification obtained is considered at the Master's level (ISCED level 7). Upon completion, students may then apply to enter a doctoral programme. (ISCED-P: 768; ISCED-A: 760)

Germany - Universitäten - zweiter Master (University studies - second Master's). Entry into these one- to two-year programmes requires the successful completion of a first Master's degree and offer more specialisation in professional and academic fields of study. The degree obtained is still considered similar to the Master's level (ISCED 7). Upon completion, students may enter doctoral studies (Promotionsstudium). (ISCED-P: 748; ISCED-A: 740)

Italy - Master di $2^{\circ}$ livello (Second level Master's). These one-year programmes may be entered following successful completion of a Master di $1^{\circ}$ livello (first level Master's of one year's duration) and offer more specialisation in a given area of study. The degree obtained is still considered to be at the Master's level (ISCED level 7). Upon completion, students may enter a Dottorato di ricerca (Research Doctorate programme). (ISCED-P: 768; ISCED-A: 760)

Kazakhstan - Резидентура, послевузовское углублённое медииинское образование (Medical residency, in-depth postgraduate medical education). These post-graduate programmes range in duration from two to four years depending on the medical speciality. Access to these programmes requires the successful completion of a first Master's degree (a combination of a general medical degree and an internship). The programmes, which include both research and classroom components in addition to a hospital-based residency, lead to a certificate of medical education completion (Свидетельство об окончании резидентуры). (ISCED-P: 768, ISCED-A: 760)

Mauritania - Formation des enseignants au secondaire (Secondary education teacher training). This one-year programme requires a Master's degree as the minimum entry requirement. By the end of the programme, graduates receive the Certificat d'aptitude au professorat de l'enseignement secondaire (CAPES), which enables holders to practise as qualified teachers in secondary education. (ISCED-P: 768, ISCED-A: 760)

Nepal - Master of Philosophy (MPhil). This is a two-year programme that requires the completion of a Master's degree for entry. By the end of the programme, graduates receive a Master's of Philosophy (MPhil) degree. (ISCED-P 768; ISCED-A 760)

Spain - Especialidades Sanitarias (Post-degree health studies). These programmes may be entered following successful completion of a first Master's degree and offer specialisation in areas related to health studies. The programmes have a duration of two to five years depending on the topic. The degree obtained (Título de Especialista Sanitariois) is still considered to be at the Master's level (ISCED level 7). These programmes generally allow access to doctoral programmes. (ISCED-P: 758; ISCED-A: 750)

Tunisia - الدراجعة في الدحاسبة (National Diploma in Auditing). This is a one-year programme following a two-year second degree programme at the Master's level in Auditing (Révision comptable). By the end of the programme, participants receive the National Diploma in Auditing (Diplôme national de la révision comptable). (ISCED-P: 768, ISCED-A: 760) 


\section{Examples Group 4:}

Stage (or programme) within a first degree at Master's or equivalent level insufficient for completion of ISCED level 7 (cumulative theoretical duration at tertiary level of less than five years), therefore leading to educational attainment at ISCED level 5 or 6 [ISCED-P: 741, 751 or 761; ISCED-A: 540, 550, 640, 650 or 660]

Tunisia - الدرحلة التحضيرية (Preparatory cycle). This programme is considered as the first stage of the national engineering diploma programme, which is classified as a long first degree at Master's level. Only elite upper secondary graduates, theoretically from age 19, may be granted access to this two-year programme. At the end of the programme, participants are awarded the national diploma of the preparatory cycle, which is only valid for pursuing the national engineering diploma programme. (ISCED-P: 761; ISCED-A: 544)

\section{Notes}

1. Paragraph numbers are references to the main ISCED 2011 classification document. See more details in the Reader's Guide.

2. Although there are as yet no internationally-agreed definitions of academic and professional orientations, some countries are applying their national definitions and making use of these codes in their ISCED mappings. 



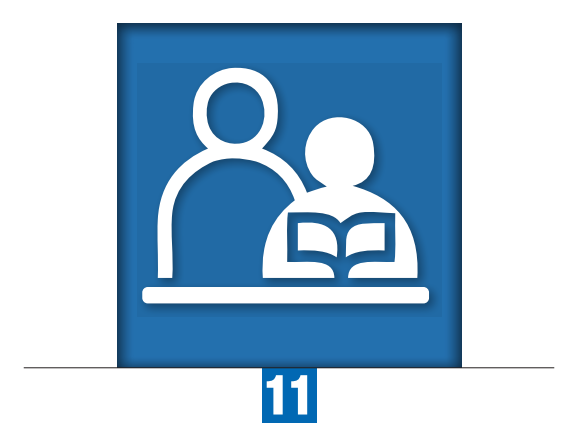

Chapter 11

\section{ISCED 2011 level 8:}

\section{Doctoral or equivalent level}

Programmes at ISCED level 8, or doctoral or equivalent level, are designed primarily to lead to an advanced research qualification. Programmes at this ISCED level are devoted to advanced study and original research and are typically offered only by research-oriented tertiary educational institutions such as universities. Doctoral programmes exist in both academic and professional fields.

The theoretical duration of these programmes is three years full-time in most countries, although the actual time that students take to complete the programmes is typically longer.

Programmes classified at ISCED level 8 may be referred to in many ways, for example: PhD, DPhil, D.Lit, D.Sc, LL.D, Doctorate or similar terms. For international comparability purposes the term, 'doctoral or equivalent level' is used to label ISCED level 8. 


\section{DESCRIPTION}

\section{Definition}

$(\S 259)^{1}$ Programmes at ISCED level 8, or doctoral or equivalent level, are designed primarily to lead to an advanced research qualification. Programmes at this ISCED level are devoted to advanced study and original research and are typically offered only by research-oriented tertiary educational institutions such as universities. Doctoral programmes exist in both academic and professional fields.

(§261) Entry into ISCED level 8 programmes or junior research positions normally requires the successful completion of specific ISCED level 7 programmes. ISCED level 8 requires at least three years of full-time equivalent study, making a total cumulative duration of at least seven years of full-time education at the tertiary level.

(\$260) ISCED level 8 usually concludes with the submission and defence of a thesis, dissertation or equivalent written work of publishable quality, representing a significant contribution to knowledge in the respective field of study. Therefore, these programmes are typically based on research and not only on course work.

\section{Classification criteria}

\section{Main criteria}

a) Written work requirements

(§260) ISCED 8 programmes require the submission of a thesis, dissertation or equivalent written work of publishable quality that is the product of original research and represents a significant contribution to knowledge in the respective field of study.

b) Entry requirements

(§261) Entry into ISCED level 8 programmes or junior research positions normally requires the successful completion of specific ISCED level 7 programmes.

c) Minimum duration of level

(§265) ISCED level 8 requires at least three years of full-time equivalent study.

\section{Subsidiary criteria}

a) Doctoral degree/qualification required for specific occupations

(§266) Achievement of an ISCED level 8 qualification is often a condition for entering into faculty posts in educational institutions that offer ISCED level 6, 7 and 8 programmes, as well as research posts in government and industry.

\section{Complementary dimensions}

(§268) One dimension may be used to differentiate education programmes at ISCED level 8:

(§269) Programme orientation

- Academic; and

- Professional2. 


\section{CORRESPONDENCE BETWEEN ISCED 2011 AND ISCED 1997}

See correspondence section in the tertiary education chapter.

\section{GUIDELINES FOR CLASSIFYING PROGRAMMES AND THEIR RELATED RECOGNISED QUALIFICATIONS AT ISCED LEVEL 8}

This level is reserved for tertiary programmes that lead directly to the award of an advanced research qualification. The theoretical duration of these programmes is three years full-time in most countries (for a cumulative total of at least seven years full-time equivalent (FTE) at the tertiary level), although the actual time that students take to complete the programmes is typically longer. The programmes are devoted to advanced study and original research.

Programmes with a similar name to 'doctor' should only be included in ISCED level 8 if they are equivalent in complexity of content to programmes already classified at this level and fulfil the other main criteria (\$262).

These programmes are typically based on research and not only on course work. In some education systems, ISCED level 8 programmes contain very limited course work, or none at all, and individuals working towards a doctoral degree engage in research mostly independently or in small groups with varying degrees of supervision. In some education systems, doctoral research is undertaken by individuals employed by the university as junior researchers or research assistants who are undertaking at the same time their doctoral studies (§260).

Although most countries only have a 'first' advanced research qualification (Examples Group 1), some countries do award an 'intermediate' advanced research qualification prior to the doctorate (Examples Group 2). A small number of countries have 'second' advanced research qualifications (Examples Group 3). Accounting for these intermediate and second awards in the classification scheme is important for defining the boundary between the first advanced research qualifications and other qualifications at ISCED level 8.

Programmes requiring a Master's degree for entry and leading to intermediate research qualifications should be classified either as the first stage or component of ISCED level 8 programmes (where completing this component would not count as ISCED level 8 completion) or as ISCED level 7 second or further degree programmes following a Master's or equivalent. This allocation decision should be based on the degree to which the programme is designed to lead directly to the award of an advanced research qualification. It may also be helpful to consider whether students can transfer credits from this programme to a doctoral programme, or if the intermediate qualification is a requirement to enter a doctoral programme. Programmes that are primarily designed to prepare students for direct labour market entry with either basic or intermediate research skills should be classified at ISCED level 7, even if these programmes also allow students to continue studies toward an advanced research degree.

\section{EDUCATIONAL ATTAINMENT AT ISCED LEVEL 8}

(§272) For educational attainment, recognized intermediate qualifications from the successful completion of stages (or programmes) within a first degree at doctoral or equivalent level but insufficient for ISCED level 8 completion are classified at ISCED level 7.

Honorary doctorates awarded by universities on the basis of other considerations and not any research work are not recognised for the purposes of educational attainment. 


\section{EXAMPLES OF PROGRAMMES AND QUALIFICATIONS CLASSIFIED AT ISCED LEVEL 8}

(§262) Programmes classified at ISCED level 8 may be referred to in many ways, for example: PhD, DPhil, D.Lit, D.Sc, LL.D, Doctorate or similar terms. However it is important to note that programmes with a similar name to "doctor" should only be included in ISCED level 8 if they satisfy the criteria described in [ISCED 2011] Paragraph 263. For international comparability purposes, the term 'doctoral or equivalent level' is used to label ISCED level 8.

\section{Examples Group 1: \\ Programmes at doctoral or equivalent level sufficient for completion of ISCED level 8 [ISCED-P: $\mathbf{8 4 4 ,} 854$ or $\mathbf{8 6 4}$; ISCED-A: $\mathbf{8 4 0 ,} 850$ or 860 ]}

Australia - Doctor's degree or doctorate. These programmes are entered after a Bachelor's degree (high honours) or a Master's degree and usually comprise three years of full-time study devoted to preparing a substantial thesis based on an original research project resulting in a significant contribution to knowledge, understanding and/or the application of knowledge within the field of study. (ISCED-P: 864; ISCED-A: 860)

Bahrain - بر/مج الدكتوراه (Doctorate programmes). These programmes require the completion of at least a Master's degree for entry. The duration of these programmes is usually three to five years. By the end of the programme, graduates receive a Doctorate degree. (ISCED-P: 864, ISCED-A: 860)

Colombia - Doctorado (Doctorate). This is a doctorate-level programme that normally has a duration of five years. The minimum entry requirement to the programme may not necessarily include a Master's degree but at least a professional title or a university degree in the fields of technology, science, humanities, arts or philosophy. (ISCED-P: 864, ISCED-A: 860)

France - Doctorat (Doctorate). The Doctorat is a three-year programme of study following a Master's degree and represents a total of eight cumulative years of tertiary education) in fields such as the humanities, sciences, economics and law. The degree is awarded after the submission of a thesis based on original research acceptable to the responsable de l'école doctorale (Head of the doctoral school/college) or the Conseil Scientifique (Scientific Board) of the university. Candidates carry out personal research work constituting an original contribution to their chosen field of study. (ISCED-P: 864; ISCED-A: 860)

Germany - Promotionstudium. (Doctoral studies). These programmes have a duration of three to five years. In most cases, students must have successfully completed university programmes (i.e. in academic disciplines) of five to seven years prior to entering Promotion programmes. A doctoral degree is awarded to successful students on the basis of a thesis and an oral examination. A Promotionsstudium can be carried out in the form of a freie Promotion (individual supervised doctorate) which is the leading model in Germany or in the form of a strukturierte Promotion involving studies at Graduiertenkollegs (graduate colleges) or Graduiertenschulen (graduate schools). (ISCED-P: 844; ISCED-A: 840)

Italy - Dottorati di ricerca. (Doctorate of Research). This diploma is the highest academic degree awarded. It is granted after a minimum of three years spent in a university department carrying out a specific research programme under the direction of university professors. Admission to the Dottorati di ricerca is restricted and is by competitive examination among holders of the Laurea magistrale (Master's degree). (ISCED-P: 864; ISCED-A: 860)

Japan - Daigakuin Hakushi Katei (Doctorate course). The hakushi (doctoral degree) is the highest degree, awarded to students who have completed a doctorate course at a post-graduate school or who have been recognised as holding equivalent qualifications. The requirement for completion of the doctorate course is more than five years of study at a post-graduate school (in addition to four years of undergraduate studies), with 30 or more credits, the submission of a dissertation and success in a final examination. Those who have completed highly-qualified research work may be awarded the hakushi after three years' study at post-graduate school. (ISCED-P: 864; ISCED-A: 860)

United States - Doctor of Philosophy (PhD). The $\mathrm{PhD}$ is the highest academic degree and requires mastery within a field of knowledge and demonstrated ability to perform scholarly research (three to five years usually beyond the Master's degree - which is eight to ten years of cumulative tertiary study). (ISCED-P: 844 or 854; ISCED-A: 840 or 850) 


\section{Examples Group 2:}

Programmes at doctoral or equivalent level insufficient for completion of ISCED level 8 therefore leading to educational attainment at ISCED level 7 [ISCED-P: 841, 851 or 861; ISCED-A: 740, 750 or 760]

Portugal - Ensino Superior: Curso de Especialização - Curso de doutoramento (Tertiary education: Specialisation course - Doctorate course). The Curso de Especialização - Curso de doutoramento forms the first part of the Doutoramento $-3 .^{\circ} \mathrm{Ciclo}$ (third cycle of tertiary education). It consists of curricular units in research training. The diploma awarded (Especialização certification) does not confer a PhD degree. The programme is at the level of the doctorate but does not yet lead to completion of the doctoral degree. (ISCED-P: 861; ISCED-A: 760)

\section{Examples Group 3:}

Second advanced research qualification at ISCED level 8 (following a doctoral degree programme) [ISCED-P: 844, 854 or 864; ISCED-A: 840,850 or 860]

Kyrgyzstan - Послевузовское профессиональное образование, степень доктора наук (Postgraduate education, Doktor nauk programme). This is a second advanced research qualification following the послевузовское профессиональное образование, степень кандидата наук (Postgraduate education, kandidat nauk programme) leading to kandidat nauk degree, which is already classified at ISCED 8. The doktor nauk programme in general does not have any classroom component and does not necessarily require formal supervision. Usually it demands at least two years of research. By the end of the programme, graduates receive the doctor nauk degree (диплом с присвоением ученой степени доктора наук). (ISCED-P: 864; ISCED-A: 860)

\section{Notes}

1. Paragraph numbers are references to the main ISCED 2011 classification document. See more details in the Reader's Guide.

2. Although there are as yet no internationally-agreed definitions of academic and professional orientations, some countries are applying their national definitions and making use of these codes in their ISCED mappings. 



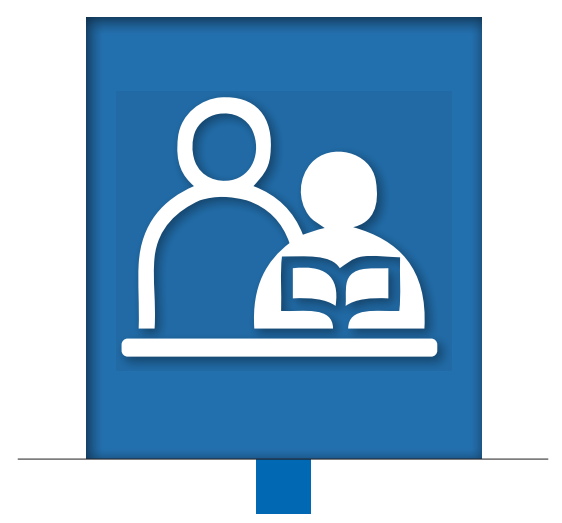

\section{Annex A}

\section{Summary table of ISCED 2011 codes and criteria}

The units of the ISCED classification are education programmes and their related recognised qualifications.

http://www.uis.unesco.org/Education/Pages/international-standardclassification-of-education.aspx

The ISCED classification uses $\mathbf{3}$ digits: the first is the educational level, the second and third are complementary dimensions.

The ISCED level of an education programme reflects the degree of complexity and specialisation of the content of the programme measured with respect to gradations of learning experiences and the knowledge, skills and competencies the programme is intended to impart. Educational attainment is measured with respect to the highest education programme successfully completed, which is normally certified by a recognised qualification. If the highest education programme is not successfully completed, the level of attainment of the person is their attainment level before entering the programme. 


\section{LEVELS AND COMPLEMENTARY DIMENSIONS OF THE INTERNATIONAL STANDARD CLASSIFICATION OF EDUCATION (ISCED) 2011}

\section{Codification of education programmes and educational attainment}

\begin{tabular}{|c|c|c|c|}
\hline \multicolumn{2}{|c|}{ Level } & \multicolumn{2}{|c|}{ Criteria for classifying national programmes by levels } \\
\hline & & Main criteria & Subsidiary criteria \\
\hline \multicolumn{2}{|c|}{ No education } & - & - \\
\hline \multirow{4}{*}{0} & \multirow{4}{*}{$\begin{array}{l}\text { Early childhood } \\
\text { education }\end{array}$} & $\begin{array}{l}\text { Learning stimulated by environment }(\S 105)^{\star} \text { or } \\
\text { in interaction with educators }(\S 106) \text {. }\end{array}$ & $\begin{array}{l}\text { Qualifications of staff: Pedagogical } \\
\text { qualifications for educators ( }(111) \text {. }\end{array}$ \\
\hline & & $\begin{array}{l}\text { Institution: school-based or centre-based } \\
(\S 107)\end{array}$ & Existence of a regulatory framework $(\$ 112)$. \\
\hline & & $\begin{array}{l}\text { Admission/age: } 3 \text { years and above for pre- } \\
\text { primary education }(\$ 102 / 108) \text {. }\end{array}$ & Typically not compulsory (§113). \\
\hline & & $\begin{array}{l}\text { Intensity: } 2 \text { hours of education per day and } \\
100 \text { days a year }(\$ 110) \text {. }\end{array}$ & \\
\hline \multirow{3}{*}{1} & \multirow{3}{*}{$\begin{array}{l}\text { Primary } \\
\text { education }\end{array}$} & $\begin{array}{l}\text { Education with systematic teaching and } \\
\text { learning in reading, writing and mathematics } \\
\text { (§125). }\end{array}$ & $\begin{array}{l}\text { Often coincides with the beginning of } \\
\text { compulsory education ( }(127) \text {. }\end{array}$ \\
\hline & & $\begin{array}{l}\text { Admission/age and duration: official age of entry } \\
\text { between ages } 5 \text { and } 7 \text { years; typical duration of } \\
6 \text { years (range is } 4 \text { to } 7 \text { years) ( } \$ 122) \text {. }\end{array}$ & \\
\hline & & $\begin{array}{l}\text { Teacher: typically one main teacher is in } \\
\text { charge of a group ( } \$ 126) \text {. }\end{array}$ & \\
\hline \multirow{3}{*}{2} & \multirow{3}{*}{$\begin{array}{l}\text { Lower secondary } \\
\text { education }\end{array}$} & $\begin{array}{l}\text { Transition to subject-oriented instruction } \\
(\S 144) \text {. }\end{array}$ & $\begin{array}{l}\text { Typical entry age is between } 10 \text { and } 13 \text { years, } \\
\text { the most common being } 12(\$ 141) \text {. }\end{array}$ \\
\hline & & $\begin{array}{l}\text { Entry requirements: completion of primary } \\
\text { education (or the capacity to study at ISCED } \\
\text { level 2) }(\$ 145) \text {. }\end{array}$ & $\begin{array}{l}\text { Subject teachers, with qualifications in } \\
\text { specific subjects as well as pedagogy ( } \$ 147) \text {. }\end{array}$ \\
\hline & & $\begin{array}{l}\text { Cumulative duration: ends after } 8 \text { to } 11 \text { years } \\
\text { of education (often } 9 \text { ) from the start of primary } \\
\text { education ( } \$ 146) \text {. }\end{array}$ & $\begin{array}{l}\text { The end of the level often coincides with the } \\
\text { end of compulsory education ( } \S 148) \text {. }\end{array}$ \\
\hline
\end{tabular}

\footnotetext{
Notes

* Paragraph numbers are references to the main ISCED 2011 classification document. See more details in the Reader's Guide.

** European Union Labour Force Survey variable HATLEVEL / HATVOC (European Commission Regulation 317/2013).
} 


\begin{tabular}{|c|c|c|c|c|c|c|}
\hline \multicolumn{4}{|c|}{ Complementary dimensions } & \multicolumn{3}{|l|}{ Coding } \\
\hline \multicolumn{2}{|c|}{$2^{\text {nd }}$ digit } & \multicolumn{2}{|c|}{$3^{\text {rd digit }}$} & $\begin{array}{l}\text { Education } \\
\text { programmes } \\
\text { ISCED-P } \\
\text { (Annex II of } \\
\text { ISCED 2011) }\end{array}$ & $\begin{array}{l}\text { Educational } \\
\text { attainment } \\
\text { ISCED-A } \\
\text { (Annex III of } \\
\text { ISCED 2011) }\end{array}$ & $\begin{array}{l}\text { EU Labour } \\
\text { Force } \\
\text { Survey } \\
\text { variable } \\
\text { HATLEVEL/ } \\
\text { HATVOC** }\end{array}$ \\
\hline \multicolumn{2}{|r|}{-} & & - & - & 010 & 000 \\
\hline \multicolumn{7}{|c|}{ Type of education: } \\
\hline 1 & $\begin{array}{l}\text { Early childhood } \\
\text { educational } \\
\text { development } \\
\text { ( } 0 \text { to } 2 \text { years) }\end{array}$ & - & - & 010 & \multirow{2}{*}{020} & - \\
\hline 2 & $\begin{array}{l}\text { Pre-primary } \\
\text { education (from } 3 \\
\text { years to the start of } \\
\text { primary education) }\end{array}$ & - & - & 020 & & 000 \\
\hline- & - & - & - & 100 & 100 & 100 \\
\hline \multicolumn{2}{|c|}{ Programme orientation: } & \multicolumn{2}{|c|}{$\begin{array}{l}\text { Level completion and access to higher } \\
\text { ISCED level: }\end{array}$} & & & \\
\hline \multirow[t]{2}{*}{4} & \multirow[t]{2}{*}{ General } & 1 & $\begin{array}{l}\text { Insufficient for level completion or } \\
\text { partial level completion (duration } \\
<2 \text { years or cumulative duration } \\
<8 \text { years since the start of ISCED } \\
\text { level 1). }\end{array}$ & 241,251 & 100 & 100 \\
\hline & & 2 & $\begin{array}{l}\text { Partial level completion (intermediate } \\
\text { programme with duration } \geq 2 \text { years } \\
\text { and cumulative duration } \geq 8 \text { years). }\end{array}$ & 242,252 & 242,252 & 200 \\
\hline \multirow{2}{*}{5} & \multirow{2}{*}{ Vocational } & 3 & $\begin{array}{l}\text { Level completion without direct access } \\
\text { to ISCED } 3 \text { (duration } \geq 2 \text { years, } \\
\text { cumulative duration } \geq 8 \text { years). }\end{array}$ & 243,253 & 243,253 & 200 \\
\hline & & 4 & $\begin{array}{l}\text { Level completion with direct access } \\
\text { to ISCED } 3 \text { (duration } \geq 2 \text { years, } \\
\text { cumulative duration } \geq 8 \text { years). }\end{array}$ & 244,254 & 244,254 & 200 \\
\hline
\end{tabular}

\section{Notes}

* Paragraph numbers are references to the main ISCED 2011 classification document. See more details in the Reader's Guide.

** European Union Labour Force Survey variable HATLEVEL / HATVOC (European Commission Regulation 317/2013). 


\begin{tabular}{|c|c|c|c|}
\hline \multirow{2}{*}{\multicolumn{2}{|c|}{$\begin{array}{l}\text { Level } \\
1^{\text {st }} \text { digit }\end{array}$}} & \multicolumn{2}{|c|}{ Criteria for classifying national programmes by levels } \\
\hline & & Main criteria & Subsidiary criteria \\
\hline \multirow{3}{*}{3} & \multirow{3}{*}{$\begin{array}{l}\text { Upper secondary } \\
\text { education }\end{array}$} & $\begin{array}{l}\text { Second/final stage of secondary education, } \\
\text { in form of general or vocational programmes } \\
(\S 167) \text {. }\end{array}$ & $\begin{array}{l}\text { More differentiated programmes: increased } \\
\text { range of options and streams }(\$ 169) \text {. }\end{array}$ \\
\hline & & $\begin{array}{l}\text { Entry requirements: completion of lower } \\
\text { secondary education (or the capacity to study } \\
\text { at ISCED level 3) (\$168). }\end{array}$ & \multirow[t]{2}{*}{$\begin{array}{l}\text { Teachers often more qualified with respect } \\
\text { to the subject matter they teach than lower } \\
\text { secondary teachers }(\$ 170) \text {. }\end{array}$} \\
\hline & & $\begin{array}{l}\text { Cumulative duration: programmes end } 12 \\
\text { or } 13 \text { years since the beginning of ISCED } 1 \\
\text { (§164). }\end{array}$ & \\
\hline \multirow{3}{*}{4} & \multirow{3}{*}{$\begin{array}{l}\text { Post-secondary } \\
\text { non-tertiary } \\
\text { education }\end{array}$} & $\begin{array}{l}\text { Post-secondary education, generally vocational } \\
\text { and terminal programmes preparing for the } \\
\text { labour market; typically, not considered as } \\
\text { tertiary education at the national level }(\$ 190) \text {. }\end{array}$ & \\
\hline & & $\begin{array}{l}\text { Programmes which serve to broaden } \\
\text { rather than deepen the knowledge, skills } \\
\text { and competencies of participants. Often } \\
\text { not significantly more advanced than } \\
\text { programmes at ISCED level } 3 \text { ( } \$ 191) \text {. }\end{array}$ & \\
\hline & & $\begin{array}{l}\text { Entry requirements: completion of upper } \\
\text { secondary education ( } \$ 186) \text {. }\end{array}$ & \\
\hline \multirow{3}{*}{5} & \multirow{3}{*}{$\begin{array}{l}\text { Short-cycle } \\
\text { tertiary education }\end{array}$} & $\begin{array}{l}\text { Programmes often designed to provide } \\
\text { participants with professional knowledge, skills } \\
\text { and competencies; may provide pathway to } \\
\text { academic programmes ( } \$ 207) \text {. More complex } \\
\text { than levels } 3 \text { and } 4 \text { but less than } 6(\S 212) \text {. }\end{array}$ & \multirow[t]{2}{*}{$\begin{array}{l}\text { Institutional transition points: often provided } \\
\text { by different institutions from ISCED levels } 6,7 \\
\text { and } 8 \text { (\$214). }\end{array}$} \\
\hline & & $\begin{array}{l}\text { Entry requirements: successful completion } \\
\text { of upper secondary or post-secondary non- } \\
\text { tertiary education giving access to ISCED } \\
\text { levels } 5,6 \text { or } 7(\$ 208)\end{array}$ & \\
\hline & & Minimum duration: 2 years (§213). & Typical duration: 2 to 3 years (§213). \\
\hline
\end{tabular}

\footnotetext{
Notes

* Paragraph numbers are references to the main ISCED 2011 classification document. See more details in the Reader's Guide.

** European Union Labour Force Survey variable HATLEVEL / HATVOC (European Commission Regulation 317/2013).
} 


\begin{tabular}{|c|c|c|c|c|c|c|}
\hline \multicolumn{4}{|c|}{ Complementary dimensions } & \multicolumn{3}{|l|}{ Coding } \\
\hline \multicolumn{2}{|c|}{$2^{\text {nd }}$ digit } & \multicolumn{2}{|c|}{$3^{\text {rd }}$ digit } & $\begin{array}{l}\text { Education } \\
\text { programmes } \\
\text { ISCED-P } \\
\text { (Annex II of } \\
\text { ISCED 2011) }\end{array}$ & $\begin{array}{l}\text { Educational } \\
\text { attainment } \\
\text { ISCED-A } \\
\text { (Annex III of } \\
\text { ISCED 2011) }\end{array}$ & $\begin{array}{l}\text { EU Labour } \\
\text { Force } \\
\text { Survey } \\
\text { variable } \\
\text { HATLEVEL/ } \\
\text { HATVOC** }\end{array}$ \\
\hline \multicolumn{2}{|c|}{ Programme orientation: } & \multicolumn{2}{|c|}{$\begin{array}{l}\text { Level completion and access to higher } \\
\text { ISCED level: }\end{array}$} & & & \\
\hline \multirow[t]{2}{*}{4} & \multirow[t]{2}{*}{ General } & 1 & $\begin{array}{l}\text { Insufficient for level completion or } \\
\text { partial level completion (duration } \\
<2 \text { years or cumulative duration } \\
<11 \text { years since the start of ISCED } \\
\text { level } 1 \text { ). }\end{array}$ & 341,351 & 244,254 & 200 \\
\hline & & 2 & $\begin{array}{l}\text { Partial level completion (intermediate } \\
\text { programme with duration } \geq 2 \text { years } \\
\text { and cumulative duration } \geq 11 \text { years). }\end{array}$ & 342,352 & 342,352 & $302 / 1,302 / 2$ \\
\hline \multirow{2}{*}{5} & \multirow{2}{*}{ Vocational } & 3 & $\begin{array}{l}\text { Level completion without direct } \\
\text { access to ISCED } 3 \text { (duration } \geq 2 \text { years, } \\
\text { cumulative duration } \geq 11 \text { years). }\end{array}$ & 343,353 & 343,353 & $303 / 1,303 / 2$ \\
\hline & & 4 & $\begin{array}{l}\text { Level completion with direct access } \\
\text { to ISCED } 5,6 \text { or } 7 \text { (duration } \geq 2 \text { years, } \\
\text { cumulative duration } \geq 11 \text { years). }\end{array}$ & 344,354 & 344,354 & $304 / 1,304 / 2$ \\
\hline \multicolumn{2}{|c|}{ Programme orientation: } & \multicolumn{2}{|c|}{$\begin{array}{l}\text { Level completion and access to higher } \\
\text { ISCED level: }\end{array}$} & & & \\
\hline 4 & General & 1 & $\begin{array}{l}\text { Insufficient for level completion } \\
\text { (duration }<6 \text { months) }\end{array}$ & 441,451 & 344354 & $300 / 1,300 / 2$ \\
\hline \multirow{2}{*}{5} & \multirow{2}{*}{ Vocational } & 3 & $\begin{array}{l}\text { Level completion without direct } \\
\text { access to ISCED } 5,6 \text { or } 7\end{array}$ & 443,453 & 443,453 & $400 / 1,400 / 2$ \\
\hline & & 4 & $\begin{array}{l}\text { Level completion with direct access } \\
\text { to ISCED } 5,6 \text { or } 7\end{array}$ & 444,454 & 444,454 & \\
\hline \multicolumn{2}{|c|}{ Programme orientation: } & \multicolumn{2}{|c|}{$\begin{array}{l}\text { Level completion and access to higher } \\
\text { ISCED level: }\end{array}$} & & & \\
\hline 4 & $\begin{array}{l}\text { General } \\
\text { (or academic) }\end{array}$ & 1 & $\begin{array}{l}\text { Insufficient for level completion } \\
\text { (duration }<2 \text { years) }\end{array}$ & 541,551 & 444,454 & 400 \\
\hline 5 & $\begin{array}{l}\text { Vocational } \\
\text { (or professional) }\end{array}$ & 4 & Level completion & 544,554 & 540,550 & 500 \\
\hline
\end{tabular}

\section{Notes}

* Paragraph numbers are references to the main ISCED 2011 classification document. See more details in the Reader's Guide.

** European Union Labour Force Survey variable HATLEVEL / HATVOC (European Commission Regulation 317/2013). 


\begin{tabular}{|c|c|c|c|}
\hline \multirow{2}{*}{\multicolumn{2}{|c|}{$\begin{array}{l}\text { Level } \\
1^{\text {st }} \text { digit }\end{array}$}} & \multicolumn{2}{|c|}{ Criteria for classifying national programmes by levels } \\
\hline & & Main criteria & Subsidiary criteria \\
\hline \multirow{4}{*}{6} & \multirow{4}{*}{$\begin{array}{l}\text { Bachelor's } \\
\text { or equivalent }\end{array}$} & $\begin{array}{l}\text { Programmes often designed to provide } \\
\text { participants with intermediate academic or } \\
\text { professional knowledge, skills and competencies, } \\
\text { leading to a first degree, such as a Bachelor’s, or } \\
\text { to an equivalent qualification (\$224). }\end{array}$ & $\begin{array}{l}\text { The requirement of a doctorate (ISCED } \\
\text { level 8) qualification for some of the teaching } \\
\text { staff may help distinguish ISCED levels } 5 \text { and } \\
6(\S 231) \text {. }\end{array}$ \\
\hline & & $\begin{array}{l}\text { Entry requirements: successful completion } \\
\text { of upper secondary or post-secondary non- } \\
\text { tertiary education giving access to ISCED } \\
\text { levels } 5,6 \text { or } 7 \text {; may require the passing of an } \\
\text { entrance examination (\$226). }\end{array}$ & \multirow[t]{3}{*}{$\begin{array}{l}\text { Further studies: does not give direct access } \\
\text { (usually) to doctoral programmes (ISCED } \\
\text { level 8) (§226). }\end{array}$} \\
\hline & & $\begin{array}{l}\text { Minimum cumulative duration of first degrees: } \\
3 \text { to } 4 \text { years full-time }(\$ 229) \text {. }\end{array}$ & \\
\hline & & $\begin{array}{l}\text { Position in the national degree structure: typically } \\
\text { a first degree in tertiary education; sometimes a } \\
\text { second degree of } 1 \text { to } 2 \text { years ( } \$ 230) \text {. }\end{array}$ & \\
\hline \multirow{3}{*}{7} & \multirow{3}{*}{$\begin{array}{l}\text { Master's } \\
\text { or equivalent }\end{array}$} & $\begin{array}{l}\text { Programmes often designed to provide } \\
\text { participants with advanced academic or } \\
\text { professional knowledge, skills and competencies, } \\
\text { leading to a second degree, such as a Master, or } \\
\text { to an equivalent qualification (\$241). }\end{array}$ & $\begin{array}{l}\text { Minimum duration of long } 1^{\text {st }} \text { degree: } 5 \text { years; } \\
\text { complexity of content comparable to a Master's } \\
(\S 247) \text {. }\end{array}$ \\
\hline & & $\begin{array}{l}\text { Position in the national degree structure: typically } \\
\text { a second or further degree in tertiary education } \\
\text { following a first degree at ISCED level } 6 \text { or } 7 \\
\text { ( } \$ 246 \text { ) or a long first degree of at least } 5 \text { years } \\
\text { if equivalent to a Master's in terms of the } \\
\text { complexity of content (e.g. medicine) (\$247). }\end{array}$ & \multirow[t]{2}{*}{$\begin{array}{l}\text { Further studies: often gives direct access to } \\
\text { doctoral programmes (ISCED level 8) (\$249). }\end{array}$} \\
\hline & & $\begin{array}{l}\text { Entry requirements: in the case of a } 2^{\text {nd }} \text { degree, } \\
\text { the successful completion of a Bachelor's or } \\
\text { equivalent (ISCED level } 6 \text { ) or a Master's or } \\
\text { equivalent (ISCED level } 7 \text { ) is required; in the } \\
\text { case of a } 1^{\text {st }} \text { degree, the successful completion } \\
\text { of upper secondary or of ISCED } 4 \text { granting } \\
\text { access to tertiary education is required and, } \\
\text { eventually, an entry examination (\$243). }\end{array}$ & \\
\hline \multirow{3}{*}{8} & \multirow{3}{*}{$\begin{array}{l}\text { Doctoral } \\
\text { or equivalent }\end{array}$} & $\begin{array}{l}\text { Its successful completion requires the } \\
\text { submission of a thesis or an equivalent written } \\
\text { work, of publishable quality, which is the output } \\
\text { of original research representing a considerable } \\
\text { contribution to knowledge in the field (\$264). }\end{array}$ & \multirow[t]{2}{*}{$\begin{array}{l}\text { Degree gives access to faculty positions } \\
\text { and research posts ( } \$ 266) \text {. }\end{array}$} \\
\hline & & $\begin{array}{l}\text { Entry requirements: the successful } \\
\text { completion of an ISCED } 7 \text { programme (\$261). }\end{array}$ & \\
\hline & & $\begin{array}{l}\text { Minimum duration: at least } 3 \text { years of full-time } \\
\text { studies and a total cumulative duration of at } \\
\text { least } 7 \text { years of tertiary education }(\$ 265)\end{array}$ & \\
\hline
\end{tabular}

\section{Notes}

* Paragraph numbers are references to the main ISCED 2011 classification document. See more details in the Reader's Guide.

** European Union Labour Force Survey variable HATLEVEL / HATVOC (European Commission Regulation 317/2013). 


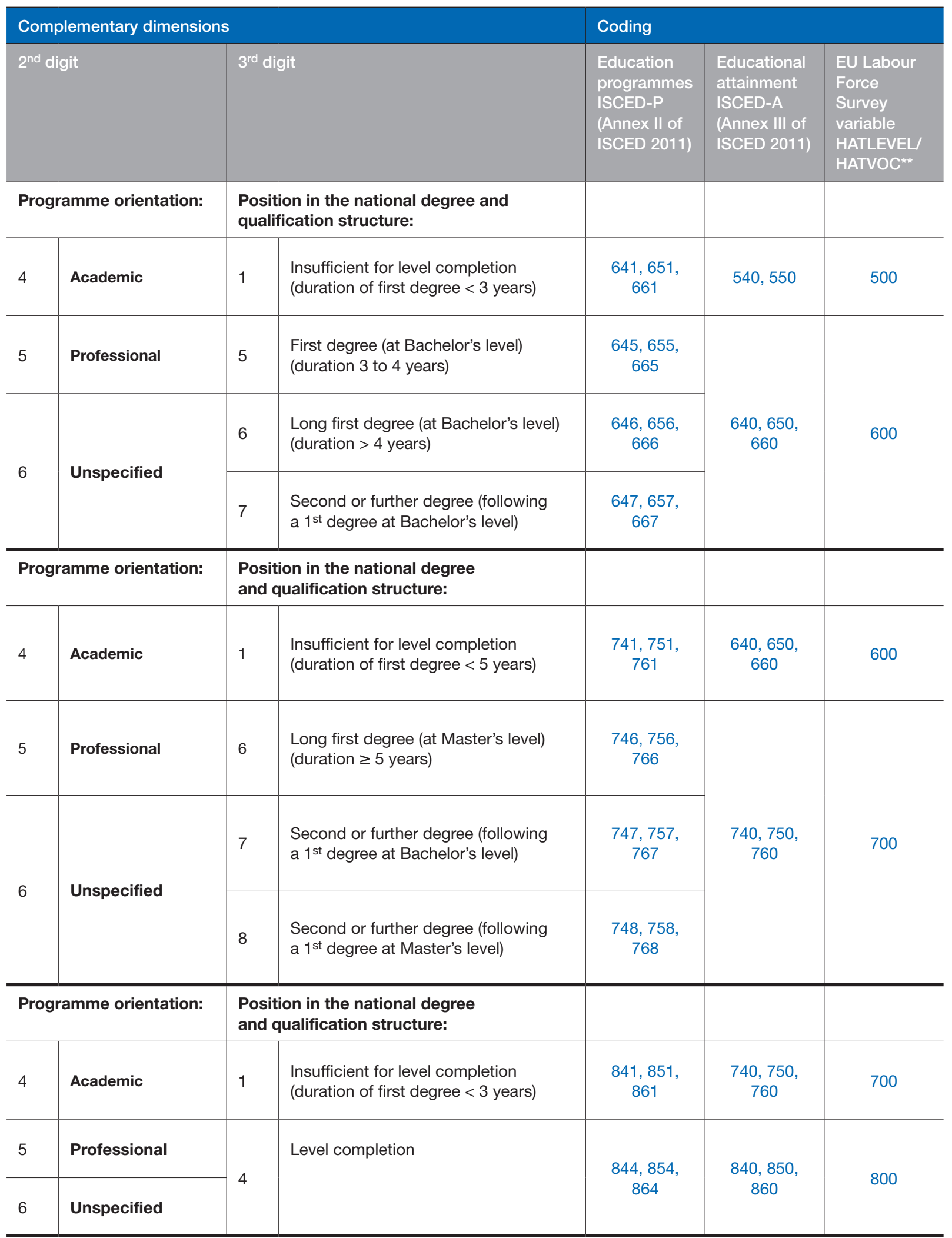

\section{Notes}

* Paragraph numbers are references to the main ISCED 2011 classification document. See more details in the Reader's Guide.

** European Union Labour Force Survey variable HATLEVEL / HATVOC (European Commission Regulation 317/2013). 



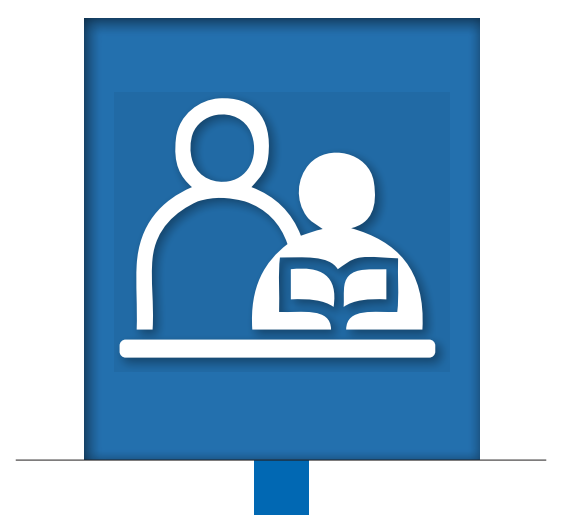

Annex B

\section{Potential educational pathways in ISCED 2011}


ISCED 2011 POTENTIAL PATHWAYS ELABORATED WITH ALL ISCED-P CODES

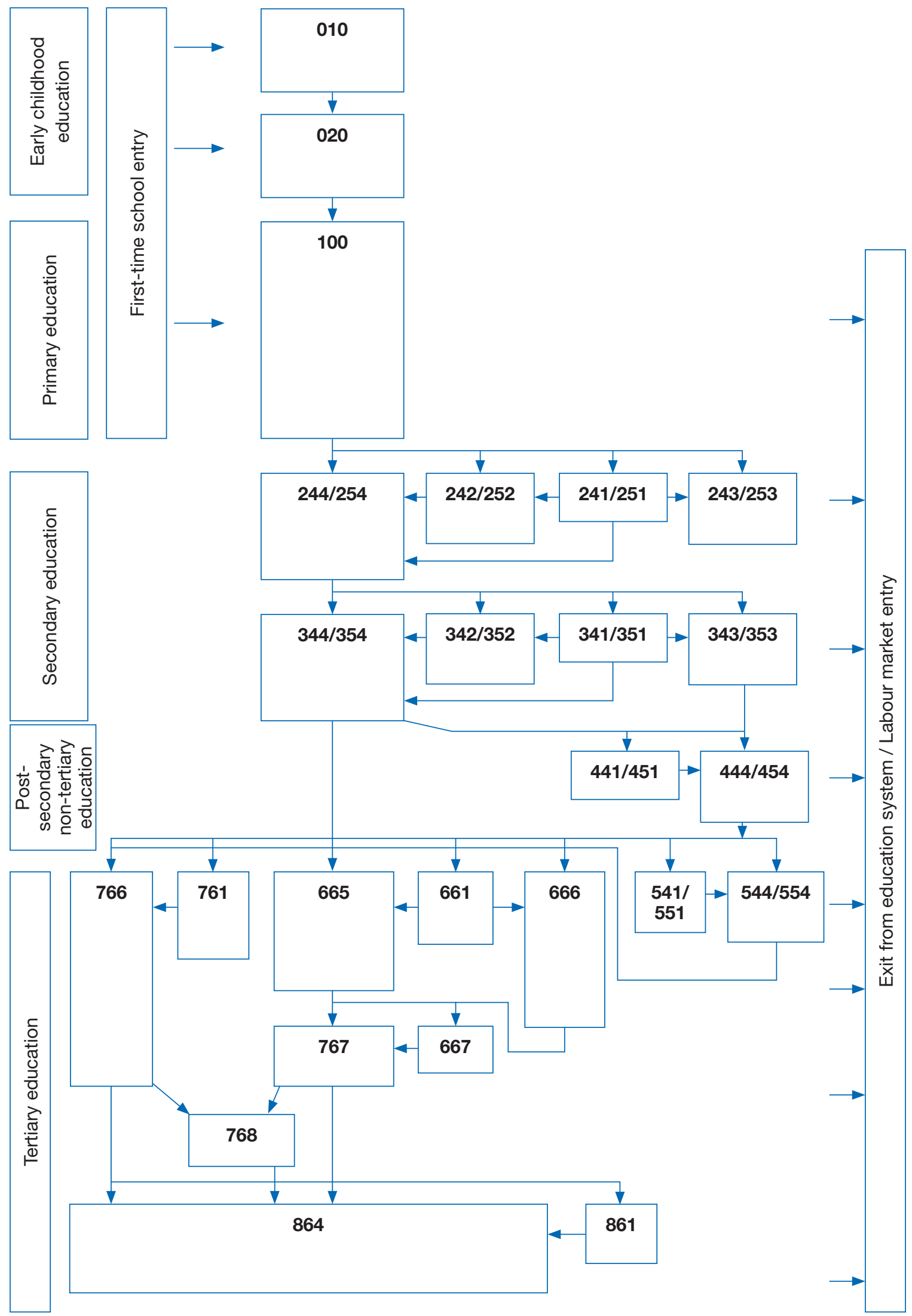




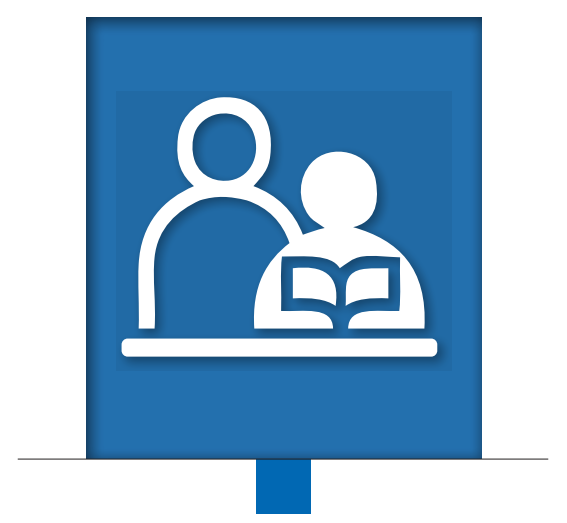

ANNEX C

\section{Quick reference of ISCED-P and ISCED-A codes in ISCED 2011}




\begin{tabular}{|c|c|c|c|}
\hline \multirow{2}{*}{$\begin{array}{l}\text { ISCED-P } \\
\text { (not applicable) }\end{array}$} & \multicolumn{2}{|l|}{ Notes on coding } & \multirow{2}{*}{$\begin{array}{l}\text { ISCED-A } \\
010\end{array}$} \\
\hline & (not applicable) & Never attended an education programme & \\
\hline 010 & Early childhood educational development & Some early childhood education & 020 \\
\hline \multirow[t]{2}{*}{020} & Pre-primary education & Some early childhood education & 020 \\
\hline & & $\begin{array}{l}\text { Some primary education (without level } \\
\text { completion) }\end{array}$ & 030 \\
\hline 100 & \multicolumn{2}{|l|}{ Primary education } & 100 \\
\hline $241 / 251$ & \multicolumn{2}{|c|}{$\begin{array}{l}\text { Lower secondary, insufficient for level completion or partial level completion, without } \\
\text { direct access to upper secondary education }\end{array}$} & 100 \\
\hline $242 / 252$ & \multicolumn{2}{|c|}{$\begin{array}{l}\text { Lower secondary, partial level completion, without direct access to upper secondary } \\
\text { education }\end{array}$} & $242 / 252$ \\
\hline $243 / 253$ & \multicolumn{2}{|c|}{$\begin{array}{l}\text { Lower secondary, level completion, without direct access to upper secondary } \\
\text { education }\end{array}$} & $243 / 253$ \\
\hline $244 / 254$ & \multicolumn{2}{|c|}{ Lower secondary, level completion, with direct access to upper secondary education } & $244 / 254$ \\
\hline $341 / 351$ & \multicolumn{2}{|c|}{$\begin{array}{l}\text { Upper secondary, insufficient for level completion or partial level completion, without } \\
\text { direct access to tertiary education }\end{array}$} & $244 / 254$ \\
\hline $342 / 352$ & \multicolumn{2}{|c|}{ Upper secondary, partial level completion, without direct access to tertiary education } & $342 / 352$ \\
\hline $343 / 353$ & \multicolumn{2}{|c|}{ Upper secondary, level completion, without direct access to tertiary education } & $343 / 353^{*}$ \\
\hline $344 / 354$ & \multicolumn{2}{|c|}{ Upper secondary, level completion, with direct access to tertiary education } & $344 / 354$ \\
\hline $441 / 451$ & \multicolumn{2}{|c|}{$\begin{array}{l}\text { Post-secondary non-tertiary, insufficient for level completion, without direct access to } \\
\text { tertiary education }\end{array}$} & $344 / 354$ \\
\hline $443 / 453$ & \multicolumn{2}{|c|}{$\begin{array}{l}\text { Post-secondary non-tertiary, level completion, without direct access to tertiary } \\
\text { education }\end{array}$} & $443 / 453^{*}$ \\
\hline $444 / 454$ & \multicolumn{2}{|c|}{ Post-secondary non-tertiary, level completion, with direct access to tertiary education } & $444 / 454$ \\
\hline $541 / 551$ & \multicolumn{2}{|c|}{ Short-cycle tertiary, insufficient for level completion } & $444 / 454$ \\
\hline $544 / 554$ & \multicolumn{2}{|l|}{ Short-cycle tertiary, level completion } & $540 / 550$ \\
\hline $641 / 651 / 661$ & \multicolumn{2}{|c|}{ Bachelor's or equivalent level, insufficient for level completion } & $540 / 550 / 560$ \\
\hline $645 / 655 / 665$ & \multicolumn{2}{|c|}{ Bachelor's or equivalent level, first degree ( 3 to 4 years) } & $640 / 650 / 660$ \\
\hline $646 / 656 / 666$ & \multicolumn{2}{|c|}{ Bachelor's or equivalent level, long first degree (more than 4 years) } & $640 / 650 / 660$ \\
\hline $647 / 657 / 667$ & \multicolumn{2}{|c|}{$\begin{array}{l}\text { Bachelor's or equivalent level, second or further degree following a Bachelor's or } \\
\text { equivalent }\end{array}$} & $640 / 650 / 660$ \\
\hline $741 / 751 / 761$ & \multicolumn{2}{|c|}{ Master's or equivalent level, insufficient for level completion } & $640 / 650 / 660$ \\
\hline $746 / 756 / 766$ & \multicolumn{2}{|c|}{ Master's or equivalent level, long first degree (at least 5 years) } & $740 / 750 / 760$ \\
\hline $747 / 757 / 767$ & \multicolumn{2}{|c|}{$\begin{array}{l}\text { Master's or equivalent level, second or further degree following a Bachelor's or } \\
\text { equivalent }\end{array}$} & $740 / 750 / 760$ \\
\hline $748 / 758 / 768$ & \multicolumn{2}{|c|}{$\begin{array}{l}\text { Master's or equivalent level, second or further degree following a Master's or } \\
\text { equivalent }\end{array}$} & $740 / 750 / 760$ \\
\hline $841 / 851 / 861$ & \multicolumn{2}{|c|}{ Doctoral or equivalent level, insufficient for level completion } & $740 / 750 / 760$ \\
\hline $844 / 854 / 864$ & \multicolumn{2}{|l|}{ Doctoral or equivalent level, level completion } & $840 / 850 / 860$ \\
\hline
\end{tabular}

\section{Note}

* ISCED-A of 343/353 and 443/453 programmes (ISCED-P) might also be 344/354 and 444/454 respectively if the minimum requirement to enter the programme already included access to tertiary education (even though the programme itself is designed to lead to the labour market instead of tertiary education). 


\section{UNESCO}

The constitution of the United Nations Educational, Scientific and Cultural Organization (UNESCO) was adopted by 20 countries at the London Conference in November 1945 and entered into effect on 4 November 1946. The Organization currently has 195 Member States and 9 Associate Members.

The main objective of UNESCO is to contribute to peace and security in the world by promoting collaboration among nations through education, science, culture and communication in order to foster universal respect for justice, the rule of law, and the human rights and fundamental freedoms that are affirmed for the peoples of the world, without distinction of race, sex, language or religion, by the Charter of the United Nations.

To fulfil its mandate, UNESCO performs five principal functions: 1) prospective studies on education, science, culture and communication for tomorrow's world; 2) the advancement, transfer and sharing of knowledge through research, training and teaching activities; 3) standard-setting actions for the preparation and adoption of internal instruments and statutory recommendations; 4) expertise through technical co-operation to Member States for their development policies and projects; and 5) the exchange of specialized information.

UNESCO is headquartered in Paris, France.

\section{UNESCO INSTITUTE FOR STATISTICS}

The UNESCO Institute for Statistics (UIS) is the statistical office of UNESCO and is the UN depository for global statistics in the fields of education, science and technology, culture and communication.

The UIS was established in 1999. It was created to improve UNESCO's statistical programme and to develop and deliver the timely, accurate and policy-relevant statistics needed in today's increasingly complex and rapidly changing social, political and economic environments.

The UIS is based in Montreal, Canada.

\section{ORGANISATION FOR ECONOMIC CO-OPERATION AND DEVELOPMENT}

The OECD is a unique forum where governments work together to address the economic, social and environmental challenges of globalisation. The OECD is also at the forefront of efforts to understand and to help governments respond to new developments and concerns, such as corporate governance, the information economy and the challenges of an ageing population. The Organisation provides a setting where governments can compare policy experiences, seek answers to common problems, identify good practice and work to co-ordinate domestic and international policies.

The OECD member countries are: Australia, Austria, Belgium, Canada, Chile, the Czech Republic, Denmark, Estonia, Finland, France, Germany, Greece, Hungary, Iceland, Ireland, Israel, Italy, Japan, Korea, Luxembourg, Mexico, the Netherlands, New Zealand, Norway, Poland, Portugal, the Slovak Republic, Slovenia, Spain, Sweden, Switzerland, Turkey, the United Kingdom and the United States. The European Union takes part in the work of the OECD.

OECD Publishing disseminates widely the results of the Organisation's statistics gathering and research on economic, social and environmental issues, as well as the conventions, guidelines and standards agreed by its members.

\section{EUROSTAT}

Eurostat is the statistical office of the European Union (EU). It is the recognised source for official European statistics and permits comparisons between the 28 EU Member States, the member countries of the European Free Trade Association (EFTA), the EU candidate countries and other neighboring countries of the EU, as well as between the regions of these countries. Eurostat cooperates closely with national statistical authorities in the EU and EFTA countries through the European Statistical System (ESS). The ESS, built up gradually with the objective of providing comparable statistics at EU level, functions as a network in which Eurostat's role is to lead the way in the harmonization of statistics. It coordinates its work with EU candidate countries, agencies and the ECB, and with international organisations such as the OECD, the UN, the International Monetary Fund and the World Bank. Eurostat's data and publications are freely available at http://ec.europa.eu/eurostat. 


\section{ISCED 2011 Operational Manual:}

\section{GUIDELINES FOR CLASSIFYING NATIONAL EDUCATION PROGRAMMES AND RELATED QUALIFICATIONS}

The structure of education systems varies widely between countries. In order to produce internationally comparable education statistics and indicators, it is necessary to have a framework to collect and report data on education programmes with a similar level of educational content. UNESCO's International Standard Classification of Education (ISCED) is the reference classification for organising education programmes and related qualifications by education levels and fields. The basic concepts and definitions of ISCED are intended to be internationally valid and comprehensive of the full range of education systems.

ISCED 2011 is the second major revision of this classification (initially developed in the 1970s and first revised in 1997). It was adopted by the UNESCO General Conference in November 2011. Prepared jointly by the UNESCO Institute for Statistics (UIS), the OECD and Eurostat, this operational manual provides guidelines and explanatory notes for the interpretation of the revised classification, by each education level. It also includes country examples of programmes and qualifications that have been classified to ISCED 2011.

This manual will be useful for national statisticians collecting and reporting data on education to international organisations, as well as for policymakers and researchers interested in better understanding of these data.

\section{Contents}

Chapter 1. ISCED 2011 overview

Chapter 2. ISCED 2011 Level 0: Early childhood education

Chapter 3. ISCED 2011 Level 1: Primary education

Chapter 4. ISCED 2011 Level 2: Lower secondary education

Chapter 5. ISCED 2011 Level 3: Upper secondary education

Chapter 6. ISCED 2011 Level 4: Post-secondary non-tertiary education

Chapter 7. Overview of ISCED 2011 tertiary education levels

Chapter 8. ISCED 2011 Level 5: Short-cycle tertiary education

Chapter 9. ISCED 2011 Level 6: Bachelor's or equivalent level

Chapter 10. ISCED 2011 Level 7: Master's or equivalent level

Chapter 11. ISCED 2011 Level 8: Doctoral or equivalent level

Consult this publication on line at: $\boldsymbol{h t t p : / / d x . d o i . o r g / 1 0 . 1 7 8 7 / 9 7 8 9 2 6 4 2 2 8 3 6 8 - e n}$

This work is published on the OECD iLibrary, which gathers all OECD books, periodicals and statistical databases.

Visit www.oecd-ilibrary.org and do not hesitate to contact us for more information.

OECDpublishing

www.oecd.org/publishing
ISBN 978-92-64-22835-1

$962015021 P$

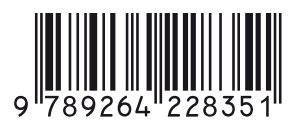

